\title{
O papel dos trilhos na estruturação territorial da cidade de São Paulo de 1867 a 1930 (versão corrigida)
}

Tese apresentada a Faculdade de Filosofia Letras e Ciências Humanas da Universidade de São Paulo para obtenção do título de Doutora em Geografia

Área de Concentração: Geografia Humana

Orientador: Prof. Dr. Reinaldo Paul Pérez Machado

Co-Orientador: Prof. Dr. Jorge Pimentel Cintra 
Kako, I.S. O papel dos trilhos na estruturação territorial da cidade de São Paulo de 1867 a 1930. Tese apresentada à Faculdade de Filosofia Letras e Ciências Humanas da Universidade de São Paulo para obtenção do título de Doutora em Geografia.

Aprovado em:

Banca Examinadora

Prof. Dr. Instituição:

Julgamento: Assinatura:

Prof. Dr. Instituição:

Julgamento: Assinatura:

Prof. Dr. Instituição:

Julgamento: Assinatura:

Prof. Dr. Instituição:

Julgamento: Assinatura:

Prof. Dr. Instituição:

Julgamento: Assinatura: 


\section{AGRADECIMENTOS}

Ao Prof. Dr. Reinaldo pela atenção, confiança e liberdade de escolhas durante a orientação da tese.

Ao Prof. Dr. Jorge Pimentel Cintra pela ajuda nos momentos de incertezas, pela dedicação e pelo aprendizado que muito contribuiu para meu crescimento científico.

Ao pessoal do Acervo Cartográfico do Arquivo Público do Estado de São Paulo que gentilmente cedeu os arquivos digitalizados dos mapas.

Ao pessoal do Acervo Fundação Energia e Saneamento pelo solícito atendimento na obtenção das imagens e leitura de relatórios.

A secretaria do Departamento de Geografia pelo atendimento nas várias ocasiões de dúvidas e encaminhamentos.

A minha família, principalmente a D.Luiza e D. Masako por cuidarem das crianças nas minhas muitas ausências para me dedicar à tese.

Ao Fábio pelo apoio e incentivo. 


\section{RESUMO}

Kako, I.S. O papel dos trilhos na estruturação territorial da cidade de São Paulo de 1867 a 1930. 2013. 147f. Tese (Doutorado) - Faculdade de Filosofia Letras e Ciências Humanas da Universidade de São Paulo, São Paulo, 2013.

Os mapas da cidade de São Paulo, produzidos no período compreendido entre o final do século XIX e meados do século XX, revelam uma cidade em plena transformação e desenvolvimento, com aumento dos seus limites através das obras de infraestrutura, como linha férrea e de bondes, implantação dos sistemas de distribuição de água e principalmente, energia elétrica, além da construção de novas pontes, loteamentos e arruamentos de chácaras, abertura de ruas, avenidas e praças. A influência dos trilhos (trens e bondes) na estruturação territorial da cidade de São Paulo foi avaliada através da análise de mapas históricos e auxiliada pela cartografia digital. Atualmente, com os recursos técnicos disponíveis, os mapas históricos podem ser estudados de forma sistematizada buscando-se obter uma visão de conjunto a respeito das transformações no espaço geográfico ao longo do tempo. A cartografia digital, apoiada nos softwares de Sistemas de Informação Geográfica (SIG), representa essa possibilidade oferecendo recursos para armazenamento, manipulação, e visualização dos dados geográficos.

Palavras-chave: Trilhos. Bondes. Ferrovias. São Paulo. Mapas Históricos. Iconografia. Sistemas de Informação Geográfica. Cartografia. 


\begin{abstract}
Kako, I.S . The role of rail in the territorial structure of the city of São Paulo from 1867 to 1930. 2013. 147f. Tese (Doutorado) - Faculdade de Filosofia Letras e Ciências Humanas da Universidade de São Paulo, São Paulo, 2013.

The maps of the city of São Paulo produced within period from the late nineteenth and mid-twentieth century, reveal a city undergoing transformation and development, increasing the limits of the urban through infrastructure works such as railway and trams, implementation of water distribution systems and especially electricity, in addition to building new bridges, roads and subdivisions of small farms, open streets, avenues and squares. The influence of the rails (trains and trams) in the territorial structure of the city of São Paulo was evaluated through analysis of historical maps and assisted by digital mapping. Currently, with the available technical resources, historical maps can be studied in a systematic way seeking to get an overview about the changes in geographical space over time. The digital cartography supported by Geographic Information Systems (GIS) software provides resources for storage, manipulation, and visualization of geographic data.
\end{abstract}

Keywords: Rails. Trams. Trains. São Paulo. Historical Maps. Iconography. Geographic Information Systems. Cartography. 


\section{LISTA DE MAPAS}

MAPA 1_MAPA DOS CAMINHOS DE SAÍDA DE SÃO PAULO NO SÉCULO XIX

MAPA 2_MAPPA DA

CIDADE DE SÃO PAULO E SEUS SUBURBIOS- 1844/47 - C. A. BRESSER CÓPIA REPRODUZIDA EM 191856 MAPA 3_PLANTA DA CIDADE DE SÃO PAULO EM 1850- ORGANIZADA PELO ENGENHEIRO GASTÃO CÉSAR BIERRENBACH DE LIMA.

MAPA 4_PLANTA DA

CIDADE DE SÃO PAULO - 1868 - CARLOS FREDERICO RATH (ATRIBUÍDA) 65

MAPA 5_MAPPA DA CAPITAL DA P. ${ }^{\text {CIA }}$ DE S. PAULO - FR. ${ }^{D O}$ DE ALBUQUERQUE E JULES MARTIN EM $1877 \quad 70$ MAPA 6_PLANTA DA CIDADE DE SÃO PAULO LEVANTADA PELA COMPANHIA CANTAREIRA E ESGOTOS POR HENRY B. JOYNER M.I.C.E. ENGENHEIRO EM CHEFE - 1881 - CÓPIA DE DOMINGUES DOS SANTOS 74 MAPA 7_PLANTA DA CAPITAL DO ESTADO DE S. PAULO E SEUS ARRABALDES, DESENHADA E PUBLICADA POR JULES MARTIN EM 1890

MAPA 8_PLANTA GERAL DA CAPITAL DE SÃO PAULO ORGANISADA SOB A DIREÇÃO DO DR. GOMES CARDIM EM 1897

MAPA 9_PLANTA GERAL DA CIDADE DE SÃO PAULO 1905

MAPA 10_PLANTA GERAL DA CIDADE DE SÃO PAULO - LINHAS DE BONDES - 1905 - LIGHT

MAPA 11_PLANTA GERAL DA CIDADE DE SÃO PAULO COM INDICAÇÕES DIVERSAS- ORGANIZADA PELA COMISSÃO GEOGRÁPHICA E GEOLÓGICA 1914 - ENG CHEFE JOÃO PEDRO CARDOSO

MAPA 12_PLANTA DA CIDADE DE SÃO PAULO- MOSTRANDO TODOS OS ARRABALDESE TERRENOS ARRUADOS

$$
-1924
$$

MAPA 13_MAP OF THE CITY OF SÃO PAULO SHOWING PUBLIC UTILITIES OPERATED BY SUBSIDIARY COMPANIES $-1924$

MAPA 14_PLAN OF THE CITY OF SÃO PAULO AND ENVIRONS_1927

MAPA 15_MANCHA URBANA DE SÃO PAULO EM 1847 SOBRE MAPA ORIGINAL

MAPA 16_MANCHA URBANA DE SÃO PAULO EM 1847 COM DIVISÃO DISTRITAL ATUAL

MAPA 17_MANCHA URBANA DE SÃO PAULO EM 1868 SOBRE MAPA ORIGINAL

MAPA 18_MANCHA URBANA DE SÃO PAULO EM 1868 COM DIVISÃO DISTRITAL ATUAL

MAPA 19_MANCHA URBANA DE SÃO PAULO EM 1881 SOBRE MAPA ORIGINAL

MAPA 20_MANCHA URBANA DE SÃO PAULO EM 1881 COM DIVISÃO DISTRITAL ATUAL

MAPA 21_MANCHA URBANA DE SÃO PAULO EM 1890 SOBRE MAPA ORIGINAL

MAPA 22_MANCHA URBANA DE SÃO PAULO EM 1890 COM DIVISÃO DISTRITAL ATUAL

MAPA 23_MANCHA URBANA DE SÃO PAULO EM 1897 SOBRE MAPA ORIGINAL

MAPA 24_MANCHA URBANA DE SÃO PAULO EM 1897 COM DIVISÃO DISTRITAL ATUAL 
MAPA 27_USO DE POLÍGONOS DE THIESSEN PARA REPRESENTAR ÁREA DE INFLUÊNCIA POR BAIRRO EM 1905 SÃO PAULO

MAPA 28_MANCHA URBANA E LINHAS DE BONDES DE SÃO PAULO - 1914

MAPA 29_LINHAS DE BONDES - SÃO PAULO ÁREA CENTRAL - 1905

127

MAPA 30 _LINHAS DE BONDES - SÃO PAULO ÁREA CENTRAL - 1914

128

MAPA 31_MANCHA URBANA DE 1924 - SÃO PAULO

MAPA 32_LINHAS DE BONDES - SÃO PAULO - 1924

131

MAPA 33_CRESCIMENTO DA MANCHA URBANA DE SÃO PAULO - 1847-1890

133

MAPA 34_CRESCIMENTO DA MANCHA URBANA 1890-1927 - SÃO PAULO 


\section{LISTA DE QUADROS}

QUADRO 1_PARALELISMOS ICONOGRÁFICOS ENTRE A ARTE E A CARTOGRAFIA (HARLEY, LA NUEVA NATURALEZA DE LOS MAPAS, 2005, P. 75) TRAD.NOSSA

QUADRO 2_CARACTERÍSTICAS DO MAPA BASE UTILIZADO PARA O GEOREFERENCIAMENTO. MOSTRA O SISTEMA DE COORDENADAS E PROJEÇÃO, UNIDADE DE MEDIDA, SISTEMA DE COORDENADAS GEOGRÁFICAS, DATUM, MERIDIANO E UNIDADE DE MEDIDA ANGULAR DO MAPA UTILIZADO COMO BASE PARA GEOREFERENCIAR OS MAPAS HISTÓRICOS ANALISADOS NO ESTUDO.

QUADRO 3_CARACTERÍSTICAS PRINCIPAIS DOS SISTEMAS DE INFORMAÇÃO GEOGRÁFICA, SEGUNDO MODELO DE DADOS GRÁFICO UTILIZADO (ELABORAÇÃO REINALDO P. PÉREZ MACHADO, 2010) 


\section{LISTA DE FIGURAS}

FIGURA 1_DETALHE DA SOBREPOSIÇÃO DA BASE CARTOGRÁFICA DIGITAL (COLORIDA) DA CIDADE DE SÃO PAULO “Á PLANTA GERAL DA CAPITAL DE SÃO PAULO 1897” (PÉREZ MACHADO, 2010, P. 15)

FIGURA 2_IMAGEM DA TELA DO PROGRAMA ARCGIS 9.3 MOSTRANDO O “MAPPA DA CIDADE DE SÃO PAULO E SEUS SUBURBIOS DE C. A. BRESSER - 1844/47"

FIGURA 3_DETALHE DO MAPA “MAPPA DA CIDADE DE SÃO PAULO E SEUS SUBURBIOS DE C. A. BRESSER 1844/47"

FIGURA 4_PONTOS DE CONTROLE UTILIZADOS NO GEOREFERENCIAMENTO DA IMAGEM E TABELA COM AS COORDENADAS DOS PONTOS DE CONTROLE. VISUALIZADOS NO ARCGIS 9.3

FIGURA 5_MAPA UTILIZADO COMO BASE PARA O GEOREFERENCIAMENTO DOS MAPAS HISTÓRICOS.

FIGURA 6_TABELA COM RMS DOS PONTOS DE CONTROLE PARA O "MAPPA DA CAPITAL DO BRASIL S.PAULO 1877". MOSTRA A TABELA COM PONTOS DE CONTROLE DE GEOREFERENCIAMENTO E VALORES RESIDUAIS BAIXOS.

FIGURA 7_MAPA APÓS GEOREFERENCIAMENTO, COM EIXO EM ROTAÇÃO E ORIENTADO PARA O NORTE. VISUALIZADO NO ARCGIS 9.3. 


\section{LISTA DE TABELAS}

TABELA 1_EXTENSÃO DAS LINHAS DE BONDES EM METROS PARA O ANO DE 1886.

.26

TABELA 2_NÚMERO DE PASSAGEIROS TRANSPORTADOS POR BONDES EM SÃO PAULO DE 1890 A 1894..........27

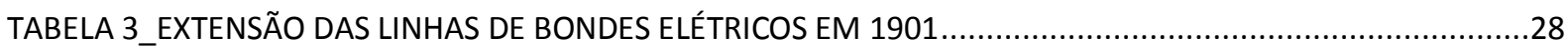

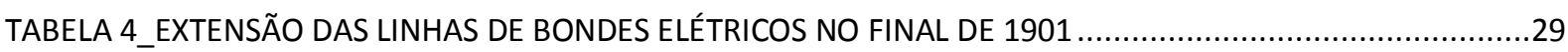

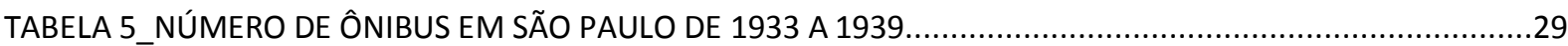

TABELA 6_LISTAGEM DOS MAPAS DE SÃO PAULO DE 1765 A 1927 COM DESTAQUE EM CINZA NOS MAPAS

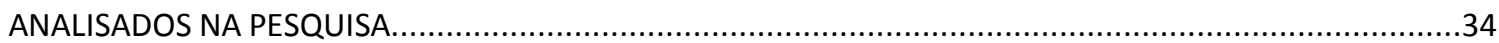




\section{LISTA DE FOTOS}

FOTO 1_CHÁCARA BRESSER_1860_TAMBÉM CONHECIDA COMO CHÁCARA DO BRÁS....................................64

FOTO 2_LARGO DO PIQUES_1862_ATUAL PRAÇA DAS BANDEIRAS............................................................ 


\section{LISTA DE SIGLAS}

DPI

Dots Per Inch (Pontos por polegada)

R.M.S ou RMS

Root Mean Square Error (valor quadrático

médio)

S.G.I.s ou SIGs Sistemas de Informações Geográficas

S.I.G ou SIG

Sistema de Informações Geográficas

S.P.R

São Paulo Railway 


\section{SUMÁRIO}

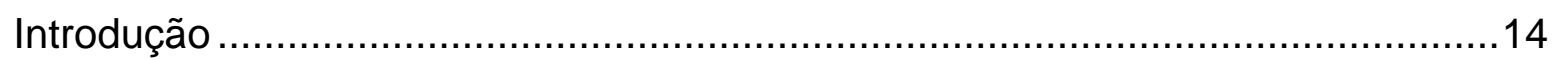

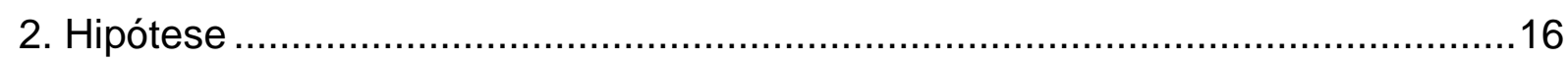

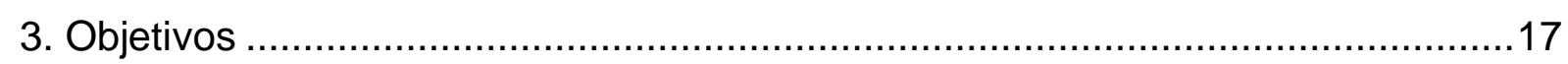

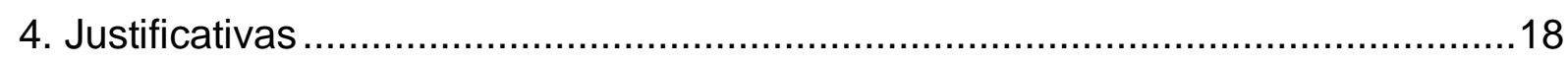

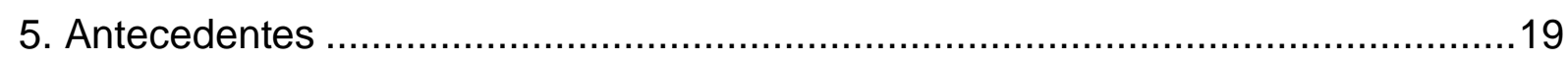

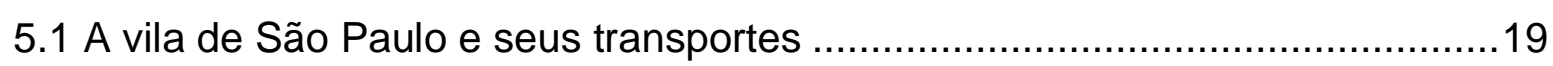

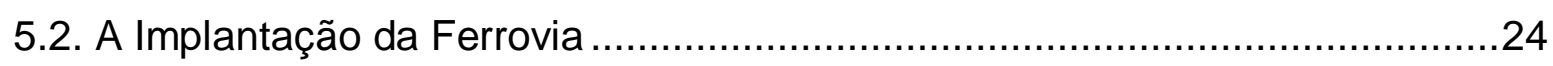

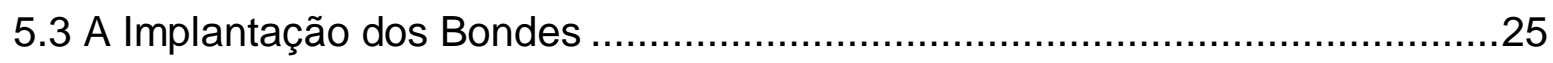

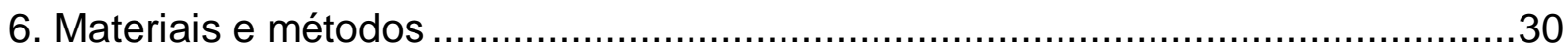

6.1 Os mapas e a expansão da cidade ...........................................................

6.2 Um método para leitura e interpretação de mapas históricos ..........................34

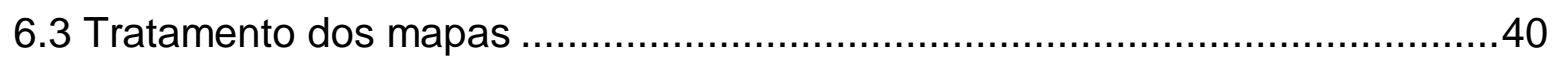

7. Proposta de Aplicação da Cartografia digital em Mapas históricos ........................48

7.1 A Cartografia Digital como instrumento de análise ........................................48

7.2 A análise dos mapas utilizados na pesquisa ...............................................54

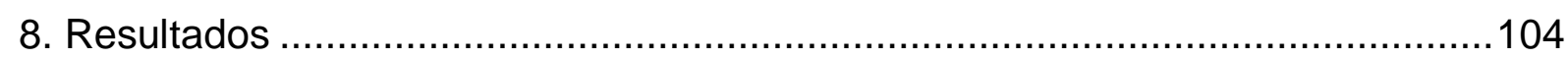

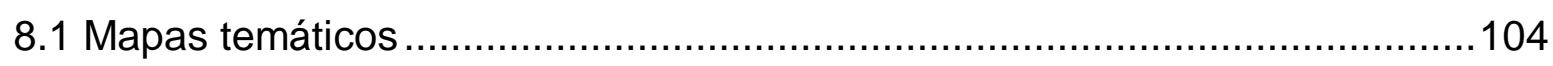

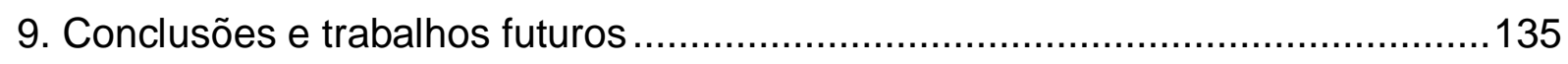

9. 1 Conclusões e verificação da hipótese .......................................................135

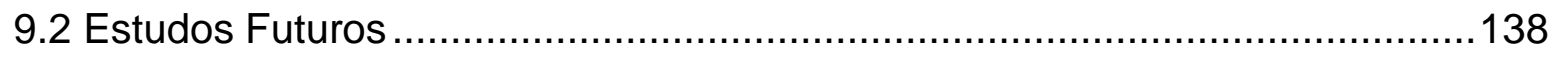

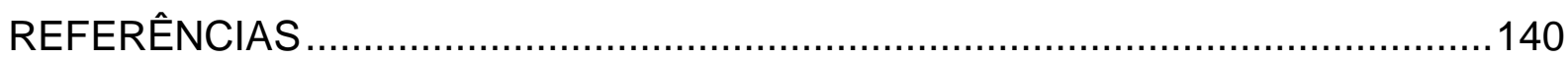

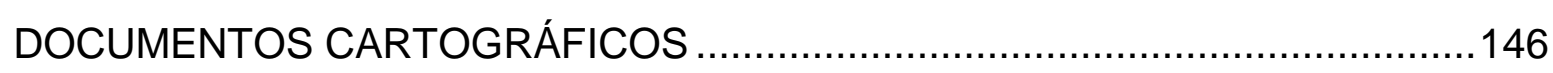

ANEXO 1 - Delimitação do centro expandido da cidade de São Paulo conforme a COMPANHIA DE ENGENHARIA DE TRÁFEGO - CET. 148 


\section{Introdução}

Este estudo tem como tema principal os trilhos na cidade de São Paulo analisados através de mapas produzidos entre o final do século XIX e as primeiras décadas do século XX. O recorte espacial deste estudo é o centro expandido ${ }^{1}$ da cidade de São Paulo.

Os mapas da cidade de São Paulo, produzidos nesse período, revelam uma cidade em plena transformação e desenvolvimento, com o aumento dos limites da urbe por meio das obras de infraestrutura, como a de linha férrea e de bondes, a implantação dos sistemas de distribuição de água, de gás e, principalmente, de energia elétrica, além da construção de novas pontes, de loteamentos e arruamentos de chácaras, de abertura de ruas, avenidas e praças. O crescimento demográfico refletiu-se diretamente no processo de expansão da área urbana da cidade através do aparecimento de novos bairros, da integração de periferias isoladas e da ocupação das várzeas. A cidade continuou a crescer nos anos seguintes em função dos processos de industrialização, de expansão do sistema viário e do aumento do número de imigrantes.

$\mathrm{Na}$ década de 50, o crescimento de São Paulo já se apresentava como tema de estudo dos geógrafos; (AZEVEDO, 1958) na sua obra "A cidade de São Paulo: Estudos de Geografia Urbana" apresenta um mapa de síntese sobre o crescimento de São Paulo no período de 1874 a 1950. E sobre os estudos geográficos da evolução urbana, (MONBEIG, 1957, p. 45) afirma a importância da análise das plantas da cidade em épocas diferentes: "A análise que acompanha a descrição desses mapas sucessivos da cidade visa explicar o porquê dos fatos e, sendo uma análise cartográfica, o porquê das direções inscritas sobre o mapa."

Os mapas históricos representam uma importante fonte de conhecimento não só para a geografia como também para outras ciências como a história, a biologia e a arquitetura. Para o estudo aqui proposto, foram selecionados 13 mapas de diferentes períodos da cidade de São Paulo. Desses mapas, a maior parte pertence ao álbum de plantas históricas intitulado "São Paulo Antigo: Plantas da Cidade", publicado pela Comissão do IV Centenário em 1954. O álbum é composto por onze

\footnotetext{
${ }^{1}$ Área delimitada conforme anexo 1 apresentado na página 148.
} 
plantas as quais apresentam a cidade do século XIX, que nesse período passou por grandes transformações em sua configuração territorial ${ }^{2}$; as suas plantas compreendem o período de 1810 a 1897.

Atualmente, com os recursos técnicos disponíveis, surge a possibilidade de analisar os mapas históricos de forma sistematizada buscando-se obter uma visão de conjunto a respeito das transformações no espaço geográfico ao longo do tempo. A cartografia digital, apoiada nos softwares de Sistemas de Informação Geográfica (SIG), representa essa possibilidade.

\footnotetext{
${ }^{2}$ A expressão "configuração territorial" definida por SANTOS (1997, p.75): "A configuração territorial é o território mais o conjunto de objetos existentes sobre ele; objetos naturais ou objetos artificiais que a definem."
} 


\section{Hipótese}

A cidade de São Paulo apresentou um grande crescimento econômico e demográfico no período entre o final do século XIX e início do século XX, passando de pouco mais de 30 mil habitantes em 1872 para aproximadamente 240 mil habitantes em $1900^{3}$. A partir de 1867 , com a inauguração da ferrovia SantosJundiaí tornou se passagem obrigatória para o trânsito de mercadorias por ela.

A partir disso a hipótese estabelecida para esta pesquisa foi a de que os trilhos (bondes e trens) apresentaram-se como um dos principais elementos estruturantes ${ }^{4}$ da ocupação do espaço urbano, atuando em conjunto com a implantação dos sistemas de água, esgoto e energia elétrica.

${ }^{3}$ Fonte de dados: FONTE - Annuario estatistico do Brazil 1908-1912. Rio de Janeiro: Directoria Geral de Estatistica, v. 1-3, 1916-1927

${ }^{4}$ VILLAÇA (2001) considera "estrutura um todo constituído de elementos que se relacionam entre si de tal forma que a alteração de um elemento ou de uma relação altera os demais elementos e todas as demais relações." (p.12) 


\section{Objetivos}

O objetivo geral deste trabalho é avaliar a influência dos trilhos no processo de urbanização da cidade de São Paulo no período de 1870 a 1930, utilizando como instrumento de análise auxiliar dos estudos geográficos a cartografia digital aplicada a mapas históricos desse período. Enfatiza-se a implantação da estrada de ferro e de outros trilhos como um dos elementos estruturantes da organização territorial da cidade de São Paulo.

Os objetivos específicos são:

- elaborar mapas temáticos a partir de uma seleção de mapas históricos da cidade de São Paulo, para ajudar a compreender como foi o processo de expansão da mancha urbana;

- identificar como os elementos presentes em mapas históricos: mancha urbana, bairros existentes, loteamentos planejados, traçado de caminhos, ferrovia, tramway e bondes e o relacionamento entre eles nas diferentes datas;

- avaliar em que medida a cartografia digital é um instrumento para essas análises. 


\section{Justificativas}

A realização desta pesquisa justifica-se na sua contribuição para os estudos geográficos, proporcionando um melhor entendimento da influência do transporte por trilhos no crescimento urbano de São Paulo, utilizando-se a cartografia histórica urbana comparativa na compreensão dos fenômenos humanos introduzidos no espaço geográfico. Ao mesmo tempo, o presente estudo oferecerá uma possibilidade do uso da cartografia digital e dos Sistemas de Informação Geográfica como instrumentos auxiliares na interpretação de mapas históricos. 


\section{Antecedentes}

Neste capítulo, serão abordados os aspectos históricos dos transportes, os transportes por trilhos e o crescimento da mancha urbana na cidade de São Paulo, enfatizando-se o período da segunda metade do século XIX até meados do século $X X$. Reforçando o enfoque deste trabalho já descrito nos objetivos, os aspectos históricos da implantação dos trilhos e o crescimento da mancha urbana serão abordados de modo a subsidiar as análises dos mapas selecionados para o estudo. Não há pretensão de aprofundamento sobre a história da cidade de São Paulo; tal enfoque tem sido abordado em estudos sobre o Brasil por competentes teóricos como Celso Furtado, em "Formação Econômica do Brasil", Sergio Buarque de Holanda, em "Caminhos e Fronteiras", entre outros que se dedicaram especificamente à cidade de São Paulo, como Caio Prado Júnior, em " A cidade de São Paulo", e Afonso de Taunay, com várias obras sobre a cidade, destacando-se "História da cidade de São Paulo"; ou por autores mais recentes, como os da coletânea organizada por Paula Porta, intitulada "História da Cidade de São Paulo"; e ainda por outros autores que serão citados ao longo deste capítulo.

\subsection{A vila de São Paulo e seus transportes}

O sítio urbano de São Paulo, desde a sua fundação em 1554 até a segunda metade do século XIX, limitou-se ao triângulo formado entre os rios Anhangabaú e Tamanduateí.

Auguste de Saint-Hilaire (SAINT- HILAIRE, 1976, p. 127), no início do século XIX, por ocasião de sua viagem à então Província de São Paulo, assim a descreve:

A cidade fica situada, como já disse, à altura dos 233' $10^{\prime \prime}$ de lat.Sul, numa elevação que constitui a parte final do planalto que se atravessa quando se vem das montanhas de Jaraguá. A seus pés se estendem várias terras planas (terrenos de várzea). Seu contorno é bastante irregular e de forma ligeiramente alongada, situando-se ela no delta formado pelos córregos Anhangabaú e Tamanduataí, os quais, após se juntarem no sopé da elevação onde fica a cidade, vão desaguar no Tietê. 
Segundo (MATOS O. N., 1990), o planalto paulista viveu uma condição de isolamento durante quase todo o período colonial devido à precariedade das comunicações entre uma região e outra.

A cidade de São Paulo estava localizada entre os caminhos indígenas da costa para o sertão, como elucida (CAMPOS, 2006, p. 30): "constata-se claramente que a constituição básica da rede viária paulistana mais remota se deu, via de regra, a partir dos eixos estruturadores representados por velhas trilhas indígenas." Ainda segundo o autor, esses caminhos como, por exemplo, Peabiru (na direção do litoral/Paraguai-sertão), Guaré, Jeritiba-Piratininga, definem e estruturam a geometria do núcleo de São Paulo que, posteriormente, ao longo do século XVII os incorporará.

Deste modo, (MARQUES, 1978) sugere três fases na estruturação da rede viária de São Paulo: a fase dos caminhos coloniais, a fase ferroviária e a rodoviária.

O chamado "primeiro período" (do século XVI até meados do século XVIII) é definido por eixos de circulação "terminais" externos, nas direções norte, leste e sul. Nessa época, o transporte era realizado basicamente por tropas de mulas, por via fluvial, com pequenas embarcações, ou a pé.

No período de restauração da capitania de São Paulo, que vai de 1748 a 1765, a região permaneceu anexada ao governo do Rio de Janeiro. Morgado de Mateus assume o governo de São Paulo nessa época, e desenvolve uma política de concessão de sesmarias voltada para o cultivo da lavoura de cana-de-açúcar. Como explica (MATOS O. N., 1990, p. 31):

Tanto a cultura da cana-de-açúcar, como a atividade troperista que caracterizou, igualmente, a vida econômica de São Paulo durante o Século XVIII, implicaram em importantes alterações no sistema de transportes e comunicações.

E foi através dessas atividades que se estabeleceu uma importante rede de caminhos ligando o planalto a outras regiões como Sorocaba - o caminho para o Sul - sede da feira de muares. As estradas do planalto foram resultado da adaptação das rotas dos bandeirantes. (MATOS O. N., 1990)

Ainda sobre tais caminhos, (BRUNO, 1954, p. 581) acrescenta: 
Com o crescimento do comércio, sobretudo de açúcar, ganharam movimento notável esses caminhos que irradiavam da cidade, e cresceram de importância os ranchos, as hospedarias e as pastagens à beira deles.

No parágrafo acima, o autor destaca também a importância dos ranchos, para descanso das tropas, das hospedarias e das pastagens situadas nos caminhos coloniais.

Segundo (MATOS O. N., 1990), foram classificadas sete estradas principais, seis delas partindo da capital. A primeira estrada para Piracicaba, passando por Itu; a segunda para Franca, passando por Jundiaí e Campinas; a terceira para Minas Gerais, passando por Atibaia; a quarta para o Norte, passando por Mogi das Cruzes, por Taubaté e indo até Bananal; a quinta, indo para Ubatuba, passando por Santos e São Sebastião; e a sexta é a última que partia de São Paulo em direção ao Paraná através de Cotia, de São Roque e de Sorocaba. O autor ainda destaca que, até o advento da estrada de ferro, a situação dos caminhos permaneceu inalterada.

Com exceção do caminho em direção ao litoral, que passaria por algumas alterações e melhorias, existiam, no século XIX, dois caminhos que seguiam de São Paulo para o litoral. A ligação entre São Paulo e o Porto de Santos é descrita por (MORSE, 1970, p. 40): "No fim do período colonial, o transporte entre São Paulo e seu porto era pouco mais rápido do que no século XVI." O autor ainda descreve o caminho como perigoso, mesmo após a construção de uma estrada pavimentada. Ainda segundo (MORSE, 1970, p. 41), "O plano de ruas de São Paulo foi polarizado por esta rota, que deixava a cidade para Santos em direção ao Sul e fez com que seus edifícios se agrupassem em torno de um eixo norte-sul." Com essa afirmação, o autor se refere ao período que vai do final do século XVIII até primeira metade do século XIX. No mapa 1 a seguir foram destacados os principais caminhos de saída da cidade no século XIX.

Como (BRUNO, 1954, p. 1059) ressalta:

É que as estradas de ferro foram desalojando de sua primitiva posição de relevo os velhos caminhos de tropas e de carros que irradiavam da cidade. Marcaram elas com novos elementos a paisagem urbana e suburbana. E representaram fatores de enorme importância em relação ao desenvolvimento e a feição da cidade. 
E, dessa forma, inicia-se a nova fase dos transportes na rede viária de São Paulo, conforme já exposto, a chamada "fase ferroviária", a qual será descrita com mais detalhes no próximo item. (MARQUES, 1978) 


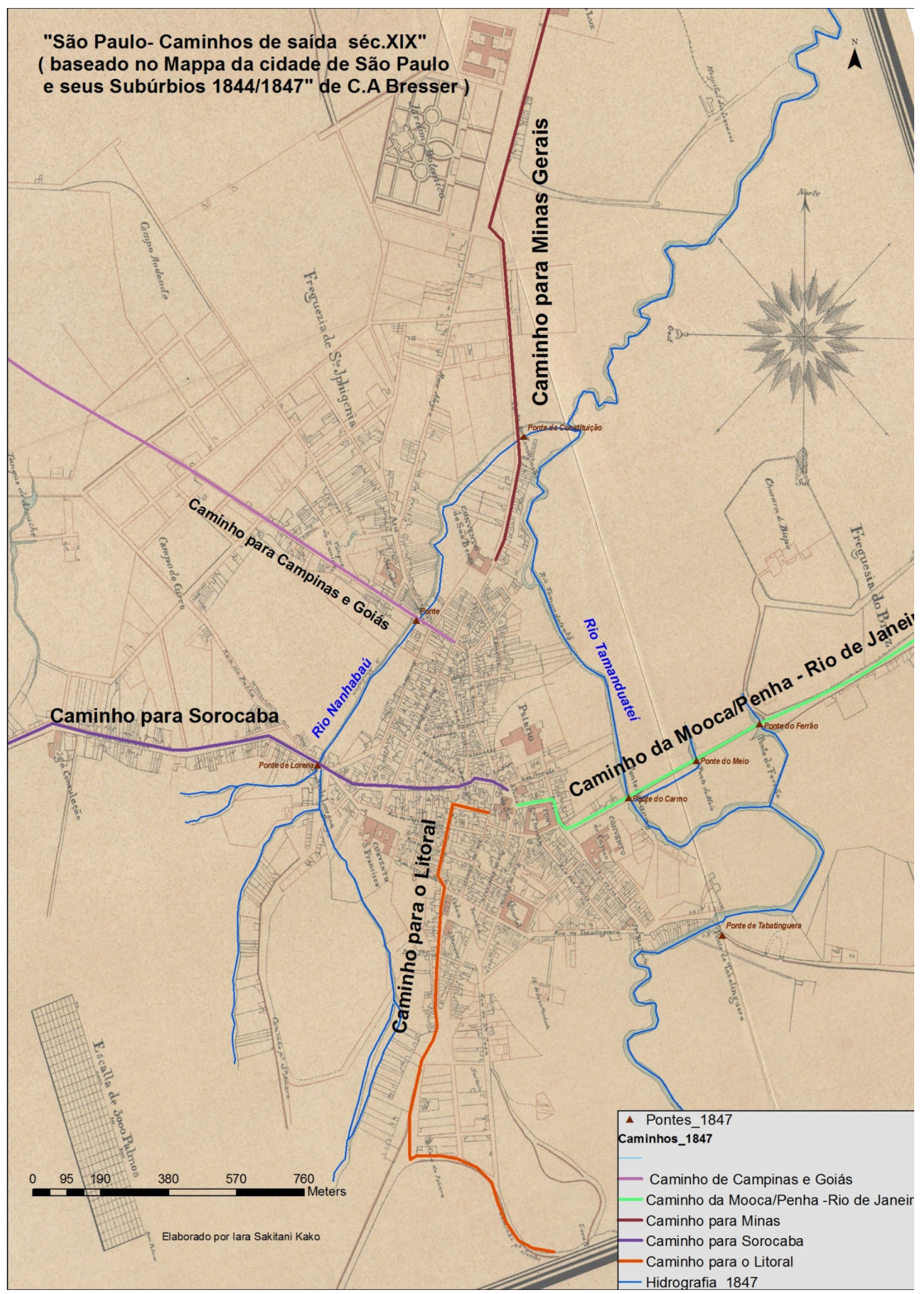

Mapa 1_Mapa dos caminhos de saída de São Paulo no século XIX 


\subsection{A Implantação da Ferrovia}

A passagem da primeira ferrovia, a São Paulo Railway de Santos a Jundiaí, por São Paulo, foi resultado de uma série de tentativas e de uma conjunção de fatores políticos, sociais e econômicos.

Para (MORSE, 1970), há uma coincidência entre as negociações de construção da ferrovia e o desenvolvimento da cidade. As primeiras tentativas de construção da ferrovia, entre 1836 e 1855, não tiveram êxito. No ano de 1860, com a iniciativa do Barão de Mauá e seus sócios, a "The São Paulo Railway Company Ldt." iniciou finalmente a construção da ferrovia.

Sobre o processo de implantação das ferrovias em São Paulo, destaca-se o estudo realizado por (SAES, 1981, p. 8), como elucida a Prof. ${ }^{a}$ Alice Piffer Canabrava, ao prefaciar o livro em referência:

[...] Flávio Azevedo Marques de Saes, com sua tese de mestrado, nos proporciona uma análise muito densa sobre o funcionamento das ferrovias, no contexto das condições da economia paulista e na dinâmica do tempo, sob perspectiva histórica.

A obra de SAES compreende em seu estudo o período de 1870 (fase de implantação das ferrovias) até 1940, época em que, segundo o autor, cristalizam-se os efeitos da crise do café de 1930, da industrialização e das mudanças no setor agrícola. As companhias ferroviárias abordadas pelo autor são: Cia. Paulista, Cia Mojiana e a Estrada de Ferro Sorocabana.

A chegada da primeira ferrovia à cidade de São Paulo, a São Paulo Railway (S.P.R.), em 1867, marca o início da decadência dos transportes feitos por tropas. A partir desse momento, os caminhos percorridos pelas tropas, as quais, até então, haviam condicionado o crescimento da cidade, perdem aos poucos sua importância. Os pousos de tropeiros, as invernadas e mesmo os vilarejos que abasteciam as tropas passam a ter um papel secundário nesse movimento.

Durante a segunda metade do século XIX, os trilhos foram instituídos em São Paulo. Primeiramente, implantou-se a ferrovia São Paulo Railway (S.P.R.), ligando Jundiaí

\footnotetext{
${ }^{5}$ Empresa formada em Londres em 1860. (MORSE, 1970)
} 
ao Porto de Santos. No mesmo período, em 1875, o trecho da ferrovia que ligava São Paulo ao Rio de Janeiro foi inaugurado, juntamente com a Estação do Norte, na Freguezia do Braz (nessa época, um pequeno núcleo urbanizado, rodeado por chácaras, destacando-se na região a Chácara do Bispo e a Bresser).

Ainda em 1875, a Companhia Estrada de Ferro Sorocabana inaugurou o trecho que passava por São Paulo, ligando-se à SPR. Assim, os principais produtos, como o café, vindos do oeste paulista, podiam ser transportados para Santos.

Entre outros fatores que explicam o crescimento da cidade a partir da década de 1870-80, (AZEVEDO, 1958, p. 12) destaca "a multiplicação das linhas férreas, no planalto paulista, tendo por fulcro binário São Paulo-Santos, e que se intensificou paralelamente ao fator anterior, nas duas últimas décadas do século passado".

Sobre a importância das estradas de ferro, (BRUNO, 1984, p. 1054) esclarece:

As estradas de ferro, além de sua importância básica para o destino da cidade, condicionando a consolidação do seu caráter de metrópole do café, valorizaram certas várzeas paulistanas até então desprezadas, fazendo com que nelas se edificassem alguns bairros operários que se integrariam no corpo urbano.

A passagem das estradas de ferro por São Paulo, o crescimento da população com o fluxo migratório e o aumento da produção do café a partir da segunda metade do século XIX são os três elementos inseparáveis na explicação do crescimento da cidade. (SAES, 1981)

O movimento de cargas que passavam por São Paulo através da ferrovia foi tão intenso que justificou a existência de um Porto Seco entre os bairros do Brás e do Pari, em 1895. (BRUNO, 1984)

A São Paulo Railway, até a década de 1930, obteve o monopólio dos transportes ferroviários entre São Paulo e Santos (MATOS O. N., 1990).

\subsection{A Implantação dos Bondes}

A implantação dos trilhos de bondes na cidade de São Paulo teve início com as obras da Cia. Ferro Carris, posteriormente denominada "Cia. Carris de Ferro de São 
Paulo", que foi autorizada a funcionar para executar o serviço de "diligências sobre trilhos de ferro", por Decreto Imperial de 08/8/1871. (STIEL, 1978)

O serviço de bondes com tração animal foi iniciado no final do ano de 1872, com seis "carros" (como eram chamados os bondes na época), logo aumentados para oito. Inicialmente, as linhas estabelecidas ligavam a região central da cidade, partindo da Rua do Carmo, com as estações de trem do Brás e da Luz. Em 1885, em apenas três anos após o início do transporte de bondes, a Cia. Carris de Ferro possuía 27 carros para transporte de passageiros, os quais possuíam de 4 a 7 assentos, e 6 carros para transporte de cargas; o número de animais para tração dos carros era de 242. (STIEL, 1978)

No ano seguinte, em 1886, a extensão das linhas de bondes na cidade era de 20.405,68 metros, distribuídos conforme a tabela 1, logo abaixo:

\begin{tabular}{|c|c|c|}
\hline \multicolumn{3}{|c|}{ Linhas de bondes 1886} \\
\hline \multicolumn{3}{|c|}{ Cia. Carris de Ferro de S. Paulo } \\
\hline & LOCALIDADES & EXTENSÃO METROS \\
\hline & Liberdade à Ponte Grande & $6.466,30$ \\
\hline & Consolação ao Largo da Sé & $4.474,20$ \\
\hline 3 & Santa Cecília ao Largo da Sé & $3.531,60$ \\
\hline & Largo do Rosário ao Brás & $3.364,10$ \\
\hline 5 & Rua do Brás à Mooca & $1.418,00$ \\
\hline 6 & Do Jardim a ligar a Rua do Comércio da Luz & 278,20 \\
\hline 7 & Da Rua do Brás à Estrada de Ferro do Norte & 72,55 \\
\hline 8 & Da Rua do Brás à Estrada Inglesa & 128,00 \\
\hline 9 & Da porteira da Estrada Inglesa na Luz à Estação & 61,00 \\
\hline 10 & Da Estação da Companhia em Santa Cecília & 93,90 \\
\hline 11 & Figueira, linha não ocupada & 105,50 \\
\hline 12 & Na estação central da Companhia & 382,33 \\
\hline 13 & Na estação central da Companhia no Brás & 30,00 \\
\hline
\end{tabular}

Fonte: (STIEL, 1978, p. 47) adaptado por lara S.Kako

Tabela 1_Extensão das linhas de bondes em metros para o ano de 1886.

Em 1889, foi formada uma nova companhia de serviços de bondes em São Paulo: a Cia. Ferro Carril de São Paulo. Essa companhia ofereceu inicialmente os ramais Bela Cintra e Cemitério, que percorriam basicamente o trecho entre o centro, a rua Augusta, a Consolação e a avenida Paulista. (STIEL, 1978) 
Dez anos depois, em 1899, cria-se a Cia. Viação Paulista para unificar as linhas de bonde em uma só companhia, porque, até então, havia diferentes proprietários de ramais de bondes na cidade, os quais ofereciam um serviço irregular aos passageiros. Ressalte-se, no entanto, que, apesar de tais irregularidades, o aumento do número dos usuários dos bondes era notável, conforme a tabela 2 a seguir:

\begin{tabular}{|c|c|}
\hline Data & Número de passageiros transportados \\
\hline 1890 & 2.886 \\
\hline 1892 & 10.887 \\
\hline 1894 & 17.742 \\
\hline \multicolumn{2}{|c|}{ (STIEL, 1978, p. 67) adaptado por lara S.Kako } \\
\hline
\end{tabular}

Tabela 2_Número de Passageiros transportados por bondes em São Paulo de 1890 a 1894.

No final do século XIX, alguns locais mais distantes do centro eram servidos por linhas de bondes, como o Ypiranga [sic], que foi servido pela linha Cambuci Ypiranga [sic] da seguinte forma: o bonde a tração animal partia do centro da cidade ao Cambuci, onde era feita a troca do sistema de tração do carro por tramway ${ }^{6}$ sem a necessidade de baldeação dos passageiros. A construção e a operação dessa linha ocorreu pelo fato de existir uma concorrência na concessão do trecho entre a Cia. Carris e um particular. A linha foi finalizada na forma descrita acima em 1892, entrando em operação pela Viação Paulista.

Ainda no mesmo período, as linhas de bondes foram prolongadas para os bairros de Santana e da Penha, que já se encontravam ligados à cidade de São Paulo através da ferrovia São Paulo-Rio de Janeiro. Em 1893 é instalado o tramway da Cantareira, realizando o percurso da Ponte Grande no rio Tietê até a Serra da Cantareira, o trecho da Liberdade até a Ponte Grande já era servido por uma linha de bonde. A linha do tramway da Cantareira foi construída pela Cia. Cantareira e Esgotos para o transporte de materiais e obras relacionados ao fornecimento de água para a cidade, e posteriormente teve seu uso também ampliado para o transporte de passageiros.

\footnotetext{
${ }^{6}$ Pequena locomotiva movida a vapor.
} 
Em 1901, devido à irregularidade dos serviços, a concessão da linha de Santana que ia da Liberdade à Ponte Grande até o Alto de Santana é conferida à The São Paulo Tramway Light and Power, substituindo o transporte a tração animal por tração elétrica, em um ramal paralelo ao já existente Tramway da Cantareira. (STIEL, 1978)

Em 1899, a The São Paulo Railway Light and Power Co., conhecida como "Light", inicia seus trabalhos de construção das primeiras linhas de bondes elétricos da cidade; já em 1900, a linha da Barra Funda é inaugurada, sendo a primeira a entrar em funcionamento. Em 1901, eram seis linhas de bondes elétricos funcionando: Avenida (circular), Barra Funda, Bom Retiro, Vila Buarque e Brás. A tabela 3, logo abaixo, mostra a extensão dessas linhas. Se comparadas em extensão com as treze linhas de tração animal existentes em 1886, estas somam uma extensão de 23, 487 $\mathrm{km}$, ou seja, três quilômetros a mais, com apenas cinco linhas, em um período de 11 anos.

\begin{tabular}{|l|r|}
\hline Linha & Extensão em Km \\
\hline Avenida (circular) & 7,489 \\
\hline Barra Funda & 3,057 \\
\hline Bom Retiro (circular) & 5,896 \\
\hline Vila Buarque & 3,595 \\
\hline Brás & 3,45 \\
\hline \multicolumn{2}{|l|}{ (STIEL, 1978, p. 145) adaptado por lara S.Kako }
\end{tabular}

Tabela 3_Extensão das linhas de bondes elétricos em 1901

Em julho de 1901, a Cia. Viação Paulista foi arrematada pela Light, e os bondes de tração animal foram aos poucos sendo substituídos pelos bondes de tração elétrica, sendo totalmente suprimidos em 1903. Assim, no final do ano de 1901, a extensão das linhas operadas pela Light após a incorporação da Cia. Viação Paulista, apresentada na tabela 4, a seguir, corresponde a um total de 83,752 quilômetros, ou melhor, 60, 265 quilômetros a mais do que as linhas operadas no início de 1901. 


\begin{tabular}{|l|r|}
\hline Linha & Extensão em Km \\
\hline Vila Buarque & 4,178 \\
\hline Bom Retiro & 6,1 \\
\hline Araçá & 4,819 \\
\hline Avenida Paulista & 7,869 \\
\hline Monsenhor Andrade & 5,124 \\
\hline Barra Funda & 7,442 \\
\hline Palmeiras & 7,442 \\
\hline Água Branca & 7,137 \\
\hline São Joaquim & 4,819 \\
\hline Liberdade & 5,124 \\
\hline Aurora & 3,385 \\
\hline Paraíso & 5,185 \\
\hline Maranhão & 3,965 \\
\hline Penha & 9,882 \\
\hline Volta no perímetro Central & 1,281 \\
\hline (STIEL, 1978, p. 148) adaptado por 1 S.
\end{tabular}

(STIEL, 1978, p. 148) adaptado por lara S.Kako

Tabela 4_Extensão das linhas de bondes elétricos no final de 1901

As linhas de bondes continuaram a ser ampliadas durante os anos seguintes aos de sua implantação, e, segundo (BRUNO, 1984, p. 1351), "[...] o número de bondes foi reduzido depois de 1920 em consequência da crise de energia elétrica determinada pelo desenvolvimento excepcional da indústria paulistana." Nessa mesma década surgem os primeiros ônibus na cidade, e em 1927 a prefeitura de São Paulo começa a demonstrar interesse em aumentar a frota de ônibus circulante que seja organizada pelo poder municipal. A tabela 5 abaixo mostra o crescimento do número de ônibus na cidade, fato que posteriormente não provocou maiores mudanças na circulação dos bondes.

\begin{tabular}{|l|l|}
\hline Ano & № de ônibus \\
\hline 1933 & 323 \\
\hline 1935 & 389 \\
\hline 1937 & 451 \\
\hline 1939 & 704 \\
\hline
\end{tabular}

(STIEL, 1978, p. 30) adaptado por lara S.Kako

Tabela 5_Número de ônibus em São Paulo de 1933 a 1939 


\section{Materiais e métodos}

Neste capítulo serão estudados, em primeiro lugar, os mapas do período de estudo de 1867 a 1930, iniciando-se com um mapa anterior à implantação da primeira ferrovia na cidade de São Paulo, o que tornará possível a construção de uma sequência temporal. A seguir, detalham-se os instrumentos conceituais para a leitura de mapas, em geral, e dos mapas históricos, em particular.

\subsection{Os mapas e a expansão da cidade}

Em seu livro "A identidade da Metrópole: a verticalização em São Paulo" (SOUZA, 1994), a autora inicia com o seguinte parágrafo: "Os geógrafos brasileiros procuram entender a sua geografia, formular explicações a respeito do processo de urbanização e, consequentemente, contribuir para a qualidade das intervenções no urbano", demonstrando a preocupação dos colegas geógrafos em compreender e explicar as modificações na cidade. Para formular tais explicações, existem vários caminhos ou metodologias que podem ser aplicadas. No presente estudo, nesse contexto, foi privilegiada a proposta de Pierre Monbeig (MONBEIG, 1957, p. 45), o qual afirma:

O modo mais perfeito de garantir o sucesso desta parte ${ }^{7}$ da monografia urbana é reunir um bom número de plantas da cidade em épocas diferentes, escolher em seguida as mais características, por exemplo as que, separadas por intervalos de tempo nem muito curtos nem muito longos, foram estabelecidas em datas críticas no passado da cidade e, finalmente, analisar essas plantas."

Foi feita uma seleção dos mapas mais significativos para a presente pesquisa em função de conterem informações relevantes sobre linhas de bonde, tramways e

\footnotetext{
${ }^{7} \mathrm{O}$ autor refere-se à etapa de analisar a evolução do espaço, que seria a primeira etapa do estudo da evolução urbana nos seus diferentes aspectos. (MONBEIG, Novos Estudos de Geografia Humana Brasileira , 1957)
} 
ferrovias, e também para que o conjunto fosse uma amostra evolutiva de maneira a poder caracterizar a evolução do espaço urbano de São Paulo. Assim, foram selecionados para pesquisa os mapas mais representativos de cada período, ou década, destacados na tabela 6 abaixo com a cor cinza.

Os mapas referem-se ao período estudado $1867-1927^{8}$.

\section{Nome do Mapa Autor}

1

Planta da

Imperial Cidade desconhecido de São Paulo

2

Planta da
Cidade de São
Paulo

Rufino José

Felizardo e Costa

1810

1765

ou

1774

Arquivo Histórico do Exercito (REIS, 2004)

Arquivo do Estado de São Paulo Reproduzida no São Paulo antigo: plantas da cidade Comissão do IV Centenário da cidade de São Paulo.

3

Planta da Imperial Cidade de São Paulo reedição de 1841

Rufino José Felizardo e Costa

1841

Reproduzida no São Paulo antigo: plantas da cidade Comissão do IV Centenário da cidade de São Paulo.

4

Planta da

Cidade de São Paulo

Carlos Abrão

Bresser

1841

Reproduzida no São Paulo antigo: plantas da cidade Comissão do IV Centenário da cidade de São Paulo.

5

Carta da Capital de São Paulo

José Jacques da Costa Ourique
Reproduzida no São Paulo antigo: plantas da cidade 1842 Comissão do IV Centenário da cidade de São Paulo.

\footnotetext{
${ }^{8}$ Pesquisa de mapas baseada em pesquisa bibliográfica e nos acervos dos Arquivos Municipal e do Estado de São Paulo e Acervo da Fundação Energia e Saneamento de São Paulo (REIS, 2004) e (PASSOS, 2009).
} 


\begin{tabular}{|c|c|c|c|c|c|}
\hline 6 & $\begin{array}{l}\text { Planta da } \\
\text { Cidade de São } \\
\text { Paulo em } 1850\end{array}$ & $\begin{array}{l}\text { César } \\
\text { Bierrenbach de } \\
\text { Lima }\end{array}$ & $\begin{array}{l}1850 \\
(1957)\end{array}$ & $\begin{array}{l}\text { Arquivo do Estado } \\
\text { de São Paulo }\end{array}$ & $\begin{array}{l}\text { Mapa } \\
\text { organizado pelo } \\
\text { engenheiro do } \\
\text { IGC Gastão } \\
\text { César } \\
\text { Bierrenbach de } \\
\text { Lima; inclui } \\
\text { nomes de } \\
\text { chácaras da } \\
\text { época }\end{array}$ \\
\hline 7 & $\begin{array}{l}\text { Planta da } \\
\text { Imperial Cidade } \\
\text { de São Paulo }\end{array}$ & Carlos Rath & 1855 & $\begin{array}{l}\text { Reproduzida no } \\
\text { São Paulo antigo: } \\
\text { plantas da cidade - } \\
\text { Comissão do IV } \\
\text { Centenário da } \\
\text { cidade de São } \\
\text { Paulo. }\end{array}$ & \\
\hline 8 & $\begin{array}{l}\text { Planta da } \\
\text { Cidade de São } \\
\text { Paulo }\end{array}$ & Carlos Rath & 1868 & $\begin{array}{l}\text { Reproduzida no } \\
\text { São Paulo antigo: } \\
\text { plantas da cidade - } \\
\text { Comissão do IV } \\
\text { Centenário da } \\
\text { cidade de São } \\
\text { Paulo. }\end{array}$ & $\begin{array}{l}\text { Primeiro mapa } \\
\text { a representar o } \\
\text { trecho da } \\
\text { ferrovia Santos- } \\
\text { Jundiaí }\end{array}$ \\
\hline 9 & $\begin{array}{l}\text { Mappa da } \\
\text { Capital da Pca. } \\
\text { de S. Paulo }\end{array}$ & $\begin{array}{l}\text { Fernando } \\
\text { Albuquerque e } \\
\text { Jules Martin }\end{array}$ & 1877 & $\begin{array}{l}\text { Reproduzida no } \\
\text { São Paulo antigo: } \\
\text { plantas da cidade - } \\
\text { Comissão do IV } \\
\text { Centenário da } \\
\text { cidade de São } \\
\text { Paulo. }\end{array}$ & $\begin{array}{l}\text { Mostra as linhas } \\
\text { de bondes a } \\
\text { tração animal } \\
\text { da época }\end{array}$ \\
\hline 10 & $\begin{array}{l}\text { Mappa } \\
\text { Topographico } \\
\text { da Cidade de } \\
\text { São Paulo }\end{array}$ & $\begin{array}{l}\text { Fernando } \\
\text { Albuquerque e } \\
\text { Carlos Rath }\end{array}$ & 1877 & $\begin{array}{l}\text { Reproduzida no } \\
\text { São Paulo antigo: } \\
\text { plantas da cidade - } \\
\text { Comissão do IV } \\
\text { Centenário da } \\
\text { cidade de São } \\
\text { Paulo. }\end{array}$ & $\begin{array}{l}\text { Segundo } \\
\text { (REIS,2004) } \\
\text { anexo de um } \\
\text { guia da cidade } \\
\text { de Abílio } \\
\text { Marques }\end{array}$ \\
\hline 11 & $\begin{array}{l}\text { Planta da } \\
\text { Cidade de São } \\
\text { Paulo }\end{array}$ & $\begin{array}{l}\text { Henry P. Joyner } \\
\text { (Cia Cantareira } \\
\text { de Águas e } \\
\text { Esgotos) }\end{array}$ & 1881 & $\begin{array}{l}\text { Reproduzida no } \\
\text { São Paulo antigo: } \\
\text { plantas da cidade - } \\
\text { Comissão do IV } \\
\text { Centenário da } \\
\text { cidade de São } \\
\text { Paulo. }\end{array}$ & $\begin{array}{l}\text { Feita pela Cia } \\
\text { Cantareira de } \\
\text { Águas e } \\
\text { Esgotos }\end{array}$ \\
\hline 12 & $\begin{array}{l}\text { Planta da } \\
\text { Capital do } \\
\text { Estado de São } \\
\text { Paulo e seus } \\
\text { Arrabaldes }\end{array}$ & Jules Martin & 1890 & $\begin{array}{l}\text { Reproduzida no } \\
\text { São Paulo antigo: } \\
\text { plantas da cidade - } \\
\text { Comissão do IV } \\
\text { Centenário da } \\
\text { cidade de São } \\
\text { Paulo. }\end{array}$ & $\begin{array}{l}\text { Expande a } \\
\text { representação } \\
\text { da cidade para } \\
\text { além da área } \\
\text { central }\end{array}$ \\
\hline 13 & $\begin{array}{l}\text { Nova Planta da } \\
\text { cidade de São }\end{array}$ & $\begin{array}{l}\text { U. Bonvicini e V. } \\
\text { Dubugras }\end{array}$ & 1891 & $\begin{array}{l}\text { Biblioteca Nacional } \\
\text { RJ (REIS, 2004) }\end{array}$ & \\
\hline
\end{tabular}


Paulo

Planta da

cidade de São

Paulo com

indicação dos

Principais

Ugo Bonvicini

1893

Arquivo do Estado

edifícios

Públicos

15

Planta da

Cidade de São

Paulo

Comissão de

Saneamento

1896

de São Paulo

16

Gomes Cardim

1897

Cidade de São

Paulo

Gomes Cardim

Reproduzida no

São Paulo antigo:

plantas da cidade - Última planta

Comissão do IV

Centenário da

cidade de São

Paulo.

17 Planta Geral da

Alexandre

Cidade de São

Paulo

Mariano Cococi e

Luis Fructoso e

1905

Costa

Biblioteca Nacional
RJ

18

Planta Geral da

Cidade de São

Paulo - Linha de

Organizada pela

Light

Biblioteca Nacional

Assinala

projetos de

retificação do

Rio

Tamanduateí

Bondes

1905

Acervo Fundação

Energia e

Saneamento - SP

produzida no

século XIX

Planta adotada

pela Prefeitura

Municipal

Organizada

pela Light

apresenta as

linhas de

bondes em

1905

19 Planta Geral da

Cidade de São Comissão

Paulo com

Geográphica e

1914

Biblioteca Nacional

Mostra as linhas de bondes de

indicações

Geológica 1914, além de fábricas.

20 Planta da

Cidade de São

Paulo

Prefeitura

Municipal

$21 \quad$ Planta da

Cidade de São

Paulo

1919

Arquivo do Estado de São Paulo

Biblioteca Nacional RJ

1916

RJ

Indicando as

novas

Circunscrições

policiais

22

Planta da

Cidade de São IGC

Prefeitura de São

Paulo_Secretaria

1924

Municipal de

Paulo

Desenvolvimento

Urbano

23

Map of the city Light

1924
Acervo Fundação

Energia e

Saneamento - SP
Mostrando

todos

arrabaldes e

terrenos

arruados

Mostra as linhas

de bondes

elétricos

existentes e

propostas 
Plan $f$ the City of

São Paulo and

Environs
Light

1927

Acervo Fundação

Energia e

Saneamento - SP de forma de expandida e localiza as propriedades da empresa em 1927.

Os limites da cidade mostrada não estão tão expandidos quanto os da planta de 1927.

Tabela 6_Listagem dos mapas de São Paulo de 1765 a 1927 com destaque em cinza nos mapas analisados na pesquisa

\subsection{Um método para leitura e interpretação de mapas históricos}

Os mapas neste estudo são compreendidos como instrumento de conhecimento de uma realidade socialmente construída (HARLEY, La Nueva Naturaleza de los Mapas, 2005) e como ferramenta de planejamento, análise e tomada de decisões, principalmente urbanísticas, com componentes e consequências sociais e políticas. Os mapas históricos enquadram-se nesse contexto e são fonte de informações para pesquisa sobre o espaço geográfico e a sociedade da sua época. Vistos sob esse aspecto, interpretá-los torna-se um desafio para aqueles que se preocupam em utilizá-los como fonte documental.

O mapa pode ser definido como uma construção social a respeito do espaço geográfico ${ }^{9}$, pois é baseado nas escolhas feitas por quem o elaborou. Adotar o par de categorias de análise tendo a configuração territorial de um lado e as relações sociais de outro permite a apreensão do objeto da geografia, como explica (SANTOS , 1997b, p.51):

\footnotetext{
${ }^{9}$ Conforme proposto por SANTOS (2004, p.20), o espaço geográfico é entendido como sinônimo de território usado, "E essa categoria, território usado, aponta para necessidade de um esforço destinado a analisar sistematicamente a constituição do território. Como se trata de uma proposta totalmente empiricizável, segue-se daí o enriquecimento da teoria."
} 
A configuração territorial é dada pelo conjunto formado pelos sistemas naturais existentes em um dado país ou uma dada área e pelos acréscimos que os homens superimpuseram a esses sistemas naturais [...] A configuração territorial, ou configuração geográfica, tem pois, uma existência material própria, mas sua existência social, isto é, sua existência real, somente lhe é dada pelo fato das relações sociais. Esta é uma forma de apreender o objeto da geografia.

As relações sociais dão significado à configuração territorial que é representada nos mapas construindo um contexto social no qual os mapas são produzidos. Cabe à geografia, cujo objeto de estudo é o espaço geográfico, fazer uso dos mapas para explicar as transformações nesse espaço.

Os mapas refletem visões de mundo dos seus construtores, e, segundo (JACOB, 1992, pp. 136-137), os mapas são a:

[...] materialização e construção de uma imagem do espaço: dentro do espírito sobretudo do cartógrafo e da sociedade a qual ele pertence. O mapa traz conhecimento sobre o mundo, as opções gerais concebidas na cosmologia, na antropologia, na filosofia global do real e do possível, do conhecido e do desconhecido, e o limite do infinito assim como da geografia.(trad.nossa)

A definição de "mapa" apresentada por Jacob mostra-se adequada à presente pesquisa por permitir a interpretação dos mapas de forma ampla e em diferentes níveis de análise: no nível análogo ao textual, tomando-se o mapa como instrumento de comunicação e utilizado, em "situações de comunicação", como uma forma de linguagem, (HARLEY, La Nueva Naturaleza de los Mapas, 2005) sugere a interpretação do mapa baseada em níveis de significado, apoiado na proposta de interpretação iconográfica de (PANOFSKY, 2009) ${ }^{10}$.

A opção pela estratégia interpretativa que utiliza os níveis de significado propostos para o estudo de mapas como obras de arte supera a interpretação dos mapas como meros instrumentos de localização de acidentes geográficos para serem a expressão de conhecimento e de "poder", estendendo para o momento da pesquisa

\footnotetext{
10 "A iconografia é, portanto, a descrição e classificação das imagens [...] é um estudo limitado e, como que ancilar, que nos informa quando e onde temas específicos foram visualizados por quais motivos específicos." (PANOFSKY, 2009, p. 53)
} 
(fim do século XIX e começo do XX) o que (HARLEY, La Nueva Naturaleza de los Mapas, 2005, p. 79) sublinha para o período colonial:

É verdade que, na geografia política e na história do pensamento geográfico, os mapas estão cada vez mais relacionados ao poder (especialmente durante os períodos da história colonial). No entanto, - papel específico dos mapas como imagens com códigos historicamente específicos permanece sendo identificado com todo o discurso geográfico em que muitas vezes se encontra inserido. (trad. Nossa $)^{11}$

Dentre as possibilidades de interpretação dos mapas históricos, destacamos a proposta feita por Harley ${ }^{12}$ de uma interpretação textual, decodificando-os por analogia com textos ${ }^{13}$, nos quais o contexto ${ }^{14}$ é um dos elementos básicos na sua interpretação.

Na definição de mapa proposta por (HARLEY, 2005, p. 62):

Os mapas são uma linguagem gráfica que se deve decodificar. São uma construção da realidade, imagens carregadas de intenções e consequências que podem ser estudadas nas sociedades de seu tempo. Como os livros, são também produto tanto das mentes individuais como dos valores culturais mais amplos em sociedades específicas. (trad. nossa). ${ }^{15}$

${ }^{11}$ Es cierto que en geografía política y en la historia del pensamiento geográfico los mapas se relacionan cada vez más con el poder (especialmente en los períodos de historia colonial). Sin embargo, el papel especifico de los mapas, como imágenes con códigos historicamente específicos, sigue siendo identificado con todo el discurso geográfico del que con frecuencia se encuentram imbuidos. (HARLEY, La Nueva Naturaleza de los Mapas, 2005)

${ }_{12}$ HARLEY, Brian J. La Nueva Naturaleza de los Mapas. Ensaios sobre la historia da cartografia. México: Fondo de Cultura Economica, 2005.

13 "Los mapas son textos en el mismo sentido en que lo son otros sistemas de signos no verbales como los cuadros, las impresiones, el teatro, el cine, la televisión, y la música."(Ibid., p.62)

14 "contexto es un conjunto complejo de fuerzas interactivas, un diálogo con el texto, dentro del cual resulta fundamental para la estrategia interpretativa."(lbid., p.64)

${ }^{15}$ Los mapas son un lenguaje gráfico que se debe decodificar. Son una construcción de la realidad, imágenes cargadas de intenciones y consecuencias que se pueden estudiar en las sociedades de su tiempo. Al igual que los libros, son también producto tanto de las mentes individuales como de los valores culturales más amplios en sociedades específicas 
O autor também destaca os aspectos do contexto que influenciam na leitura textual dos mapas. São eles: o contexto do cartógrafo, os contextos de outros mapas e o contexto da sociedade.

O contexto do cartógrafo refere-se às intenções e às circunstâncias em que o mapa foi produzido. Esse contexto não se refere apenas à autoria do mapa, que para mapas manuscritos torna-se mais óbvia, mas para o fato de que, com o advento da impressão, o trabalho de confecção do mapa foi repartido, tornando o conhecimento das técnicas empregadas nos mapas antigos um saber necessário para a sua interpretação ${ }^{16}$.

Além das técnicas, a função do mapa, ou seja, os usos que foram atribuídos a esse mapa, são uma chave interpretativa para mapas históricos. Isso é particularmente importante para os mapas utilizados no presente trabalho.

A elaboração de um mapa muitas vezes não consiste em uma atribuição somente do cartógrafo, mas de uma condição política ou de algum acontecimento social específico, fato que dificulta em muitos casos conhecer a intenção do mapa.

$\mathrm{Na}$ interpretação de mapas históricos, (CAVENAGHI, 2010) destaca a importância da busca da origem do material cartográfico estudado, assim como dos elementos ideológicos que o compõem, através da análise das representações iconográficas, sendo um bom exemplo a simbologia presente no mapa de Dom Luiz de Céspedes Xeria de 1628. (CAVENAGHI, 2010, p. 9) ressalta que:

O mapa de Xeria, constantemente reproduzido, desde a sua publicação na Colletânea de Taunay, tornou-se uma espécie de iconografia romântica dos tempos iniciais da cidade de São Paulo. Este fato não ocorreu por ação principal de seu autor original, e sim, talvez, pela interferência direta de Taunay que em sua ansiosa vontade de resgate do manancial historiográfico paulista, pode ter procurado transformar a então vila, no momento da representação do mapa de 1628, em centro principal das atenções.

No contexto de outros mapas, (HARLEY, 2005)destaca a relação do mapa em questão com outros correlatos. Esse estudo comparativo pode ser realizado com

\footnotetext{
${ }^{16}$ [tornou necesario] "saber acerca de las técnicas de navegación y topografía, estar familiarizado con los procesos mediante los cuales se compilaban, dibujaban, grababan, imprimían o coloreaban los mapas, y saber algo acerca de las prácticas comerciales de los libros y los mapas."(lbid., p.65)
} 
mapas de uma mesma área ou região, do mesmo autor, do mesmo gênero, do mesmo período, tendo sempre a referência da relação entre objetos. Nesse contexto, o estudo dos elementos icono-cartográficos que compõem o mapa pode ser feito, ou complementado, através da análise digital, do georeferenciamento e da vetorização, com o auxílio de softwares de Sistemas de Informação Geográfica (SIG). Esse tipo de análise é descrita por (RUMSEY, 2002), o qual mostra alguns exemplos de utilização do SIG na análise de mapas históricos.

O estudo da toponímia ${ }^{17}$ também oferece indícios da origem dos mapas, insere-os no contexto da sociedade, ou seja, aponta para as relações sociais estabelecidas na época. Por outro lado, mostra ou demonstra a função do mapa, fato assinalado por (KANTOR, 2009, p. 40) ${ }^{18}$ ao estudar o uso dos topônimos nas negociações diplomáticas a partir do século XVII:

[...] os mapas impressos (e as evidências toponímicas) tornaram-se um recurso jurídico na afirmação das pretensões territoriais dos impérios marítimos, em franca concorrência [...] Foi justamente a partir da segunda metade do século XVII que a reivindicação de posse com base na nomeação dos territórios passou a ser invocada com maior frequência nos tribunais europeus.

Os topônimos indígenas na maioria das vezes estavam relacionados às formações naturais dos lugares, como sugere Ab'Saber (2004, p.29): "[...] quem quiser estudar São Paulo de Piratininga e o planalto paulistano, precisará ter sempre em mente o significado dos nomes indígenas, sobretudo dos nomes tupis [...]".

No contexto da sociedade em que o mapa está inserido, (HARLEY, 2005, p. 72) explica que "Todos os mapas estão relacionados com a ordem social de um período e um lugar específicos." ${ }^{19}$ (trad. nossa)

Os mapas também são considerados objetos culturais que fazem parte da sociedade expondo seu grau de conhecimento técnico, artístico e científico.

Para examinar o contexto da sociedade, deve-se identificar as regras de ordem social que se encontram dentro dos mapas, suas representações e suas omissões (HARLEY, 2005).

\footnotetext{
${ }^{17}$ Estudo dos nomes dos lugares.

19 "Todos los mapas están relacionados con el orden social de un período y um lugar específicos."
} 
A interpretação dos mapas através da análise iconográfica busca a compreensão dos diferentes significados de uma imagem. Para tanto, (HARLEY, 2005)apresenta um quadro de paralelismos entre arte e cartografia baseado na metodologia de Erwin Panofsky. (BUENO, 2009, p. 115) sugere a mesma metodologia: "Para investigar os significados intrínsecos aos mapas [...], recomenda-se a metodologia de Erwin Panofsky para análise iconográfica e iconológica das fontes visuais".

No quadro de paralelismos entre os níveis de representação da arte e da cartografia sugerido por (HARLEY, 2005, p. 75), conforme quadro 3 a seguir, o primeiro nível na cartografia pode ser identificado como o dos símbolos utilizados, tanto de forma implícita quanto de forma explícita (em uma legenda), que podem ser analisados tanto individualmente quanto no conjunto do mapa, ou mesmo com relação a outros mapas; esses símbolos podem ser utilizados para representar tanto elementos da natureza quanto elaborações humanas: elementos naturais e antrópicos. Para (BUENO, 2009, p. 115), a distinção entre os dois principais níveis de análise ocorre da seguinte forma:

\begin{abstract}
A análise iconográfica põe luz sobre o tema primário, desconstruindo os diversos níveis da representação gráfica - conteúdo primário, instrumentos e técnicas de registro em campo e no gabinete, códigos e convenções empregados etc.; ao passo que a análise iconológica exacerba um segundo nível de investigação, mergulhando nas entrelinhas retóricas do discurso cartográfico, em busca de um estrato simbólico com conotações ideológicas nem sempre evidentes.
\end{abstract}

O segundo nível de representação cartográfica pode ser identificado como referente à identidade do lugar representado no mapa. Nesse nível, é possível a utilização dos SIGs para referenciá-lo ao "lugar real". Conforme o já exposto acima por (Bueno, 2009); já o terceiro nível de representação diz respeito à leitura simbólica, iconológica e ideológica do mapa: é nesse nível que a interpretação contextual se une à iconográfica auxiliando na dissecção do mapa. No presente estudo, será dada ênfase ao primeiro nível de análise, mas em alguns momentos explicativos, será feito o uso dos outros dois níveis interpretativos. 


\begin{tabular}{|c|c|}
\hline $\begin{array}{c}\text { Arte } \\
\text { (Usam-se os termos de Panofsky) }\end{array}$ & $\begin{array}{c}\text { Cartografia } \\
\text { (Paralelismo cartográfico sugerido) }\end{array}$ \\
\hline 1. Tema primário ou natural: motivos artísticos. & Signos convencionais individuais. \\
\hline 2. Tema secundário ou convencional. & $\begin{array}{l}\text { Identidade topográfica nos mapas: o lugar } \\
\text { específico. }\end{array}$ \\
\hline 3. Significado ou conteúdo intrínseco. & $\begin{array}{l}\text { Significado simbólico nos mapas: ideologias do } \\
\text { espaço. }\end{array}$ \\
\hline
\end{tabular}

Quadro 1_Paralelismos iconográficos entre a arte e a cartografia (HARLEY, La Nueva Naturaleza de los Mapas, 2005, p. 75) trad.nossa

\subsection{Tratamento dos mapas}

O tratamento digital de um mapa histórico começa pela aquisição da imagem do mapa no formato imagem, após adquirir a imagem digitalizada ou raster ${ }^{20}$ (figura 2) de um mapa histórico para ser analisada utilizando um software de informação geográfica executou se o georeferenciamento ${ }^{21}$ dessa imagem, tarefa essencial para etapas posteriores da pesquisa. Como explica (PÉREZ MACHADO, 2010, p. 1):

Os Sistemas de Informação Geográfica permitem colocar como fundo uma imagem matricial, - no caso um mapa histórico digitalizado ou "escanerizado" -, e sobrepor a esta uma base cartográfica digital vetorial atualizada. Se for feito o registro correto de coordenadas, orientação e de projeção cartográfica entre ambos os documentos mencionados, os resultados podem ser muito interessantes e esclarecedores.

O autor acima explica as possibilidades de utilização da cartografia digital nos Sistemas de Informação Geográfica no trabalho com mapas históricos. E mostra como o resultado visual dessa sobreposição de plantas na figura 1 a seguir.

\footnotetext{
${ }^{20}$ Um modelo de dado ou imagem raster normalmente é obtido através da digitalização, de foto aérea ou de imagem por satélite. Usualmente essas imagens não possuem informação de referências espaciais, como coordenadas geográficas ou projeção.

${ }_{21}$ Georeferenciamento de uma imagem consiste em atribuir a ela dados referentes às coordenadas geográficas e à projeção.
} 


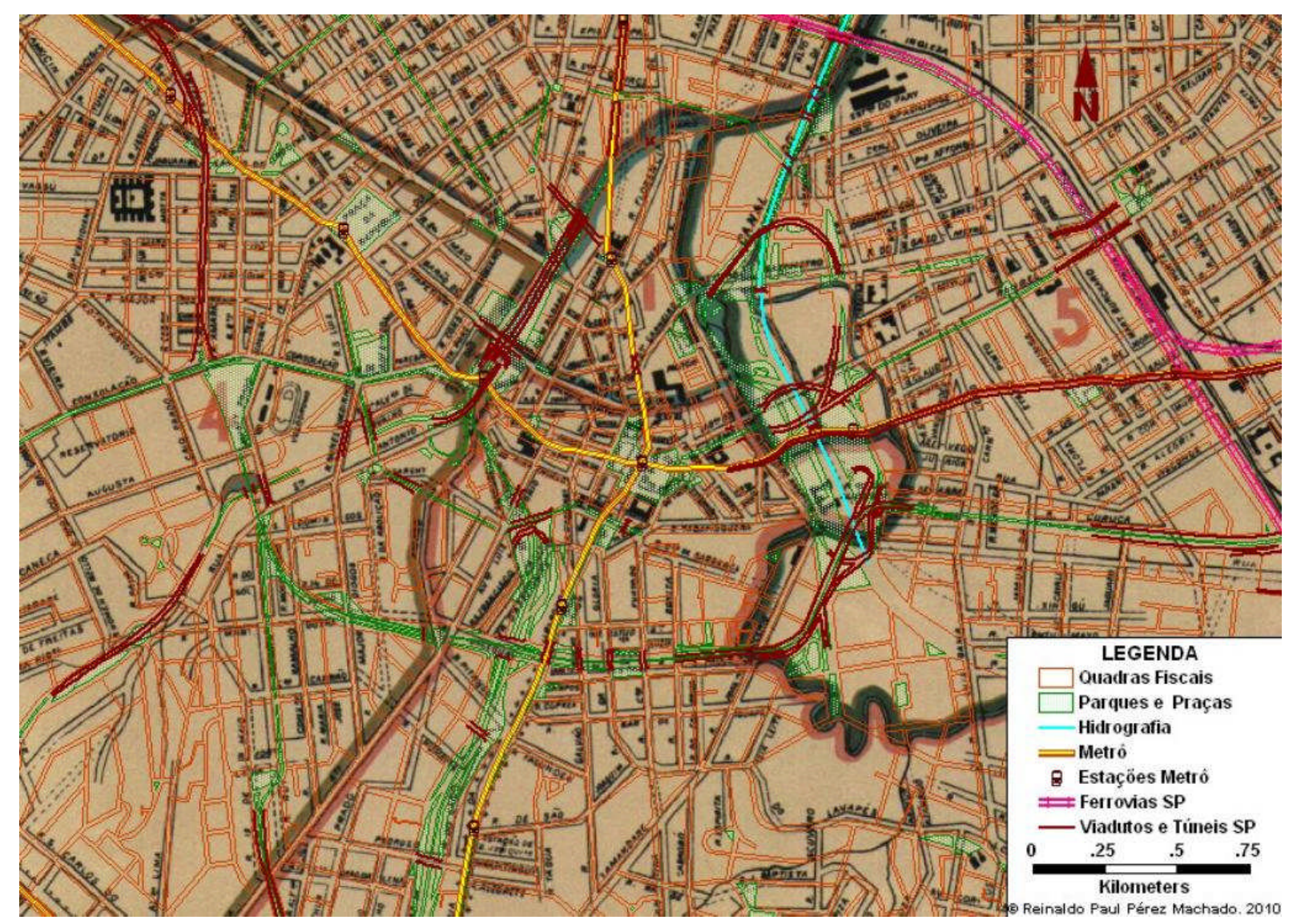

Figura 1_Detalhe da sobreposição da base cartográfica digital (colorida) da Cidade de São Paulo “Á Planta Geral da capital de São Paulo 1897” (PÉREZ MACHADO, 2010, p. 15)

A visualização da imagem no formato digital constituiu a primeira etapa de trabalho com mapas históricos utilizando os Sistemas de Informação Geográfica, a qualidade da imagem deve ser compatível com o grau de detalhamento das informações que o pesquisador deseja extrair do mapa.

Para elucidar tal fato a figura 2 apresenta a imagem completa do mapa histórico, em formato raster, visualizado no ArcGis. 


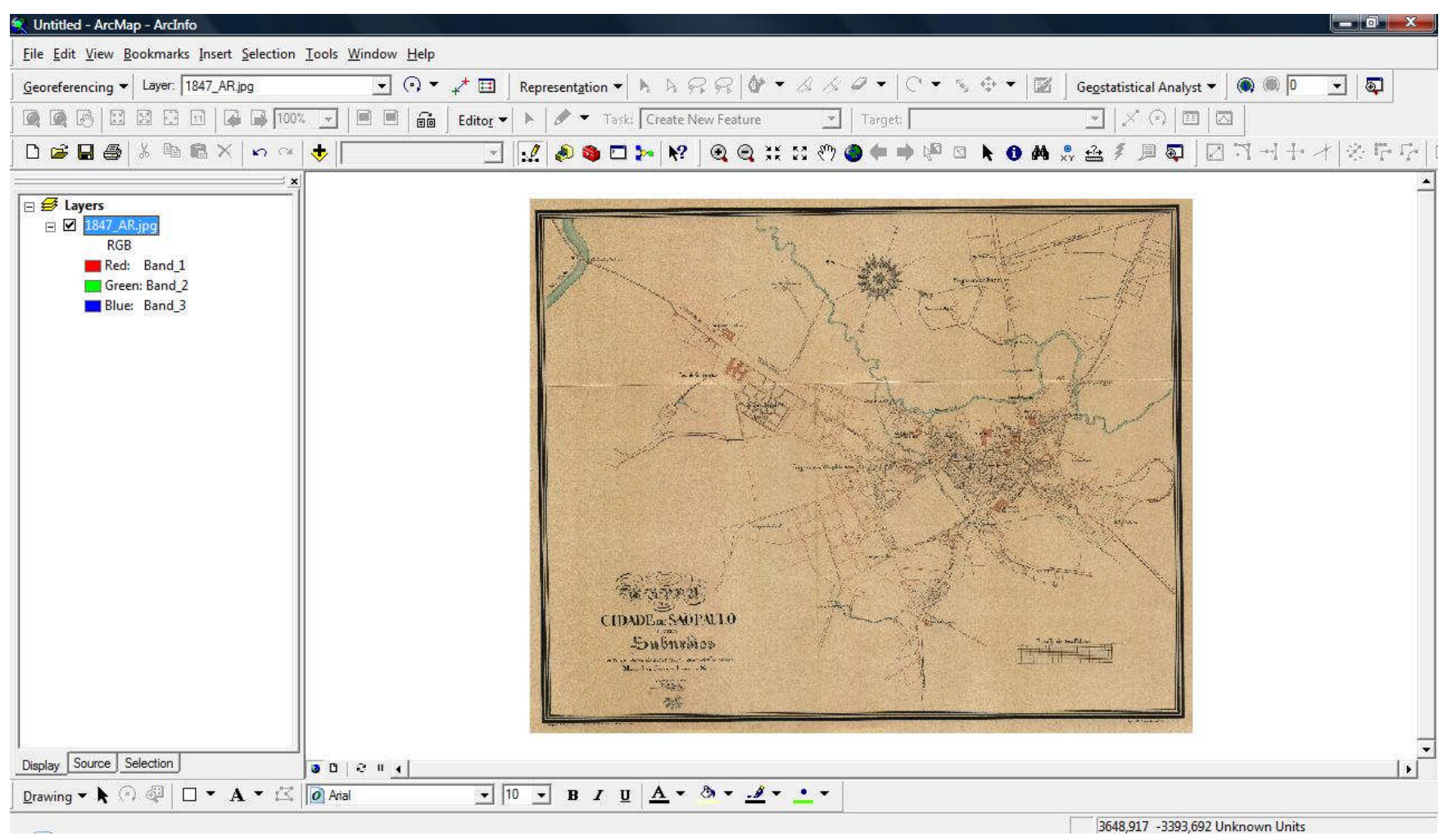

Figura 2_Imagem da tela do programa ArcGis 9.3 mostrando o "MAPPA DA CIDADE DE SÃO PAULO E SEUS SUBURBIOS de C. A. Bresser - 1844/47”"

Por exemplo, se a necessidade é extrair do mapa apenas os elementos de fácil visualização, como os maiores rios ou a mancha urbana, no geral, a imagem pode ter uma resolução de aproximadamente 150 DPI (dots per inch) ${ }^{22}$; porém, se o pesquisador pretende extrair ou visualizar no mapa ruas, hidrografia detalhada, edifícios, pontes e outros elementos visíveis apenas em mapas com escala grande, como 1:5000, então, a resolução da imagem deve ser acima de 200 DPI (dots per inch), para que o mapa possa ser ampliado, permitindo-se assim a visualização de detalhes.

A figura 2 mostra um mapa digitalizado do original no formato JPG, com 2,79 MB de tamanho, com uma resolução de 200 DPI que permite visualizar detalhes como ruas, córregos, edifícios e pontes. O mapa exibido é visualizado no software ArcGis 9.3. A figura 3 a seguir mostra o detalhe do mesmo mapa com a visualização ampliada.

\footnotetext{
22 Pontos por polegada.
} 


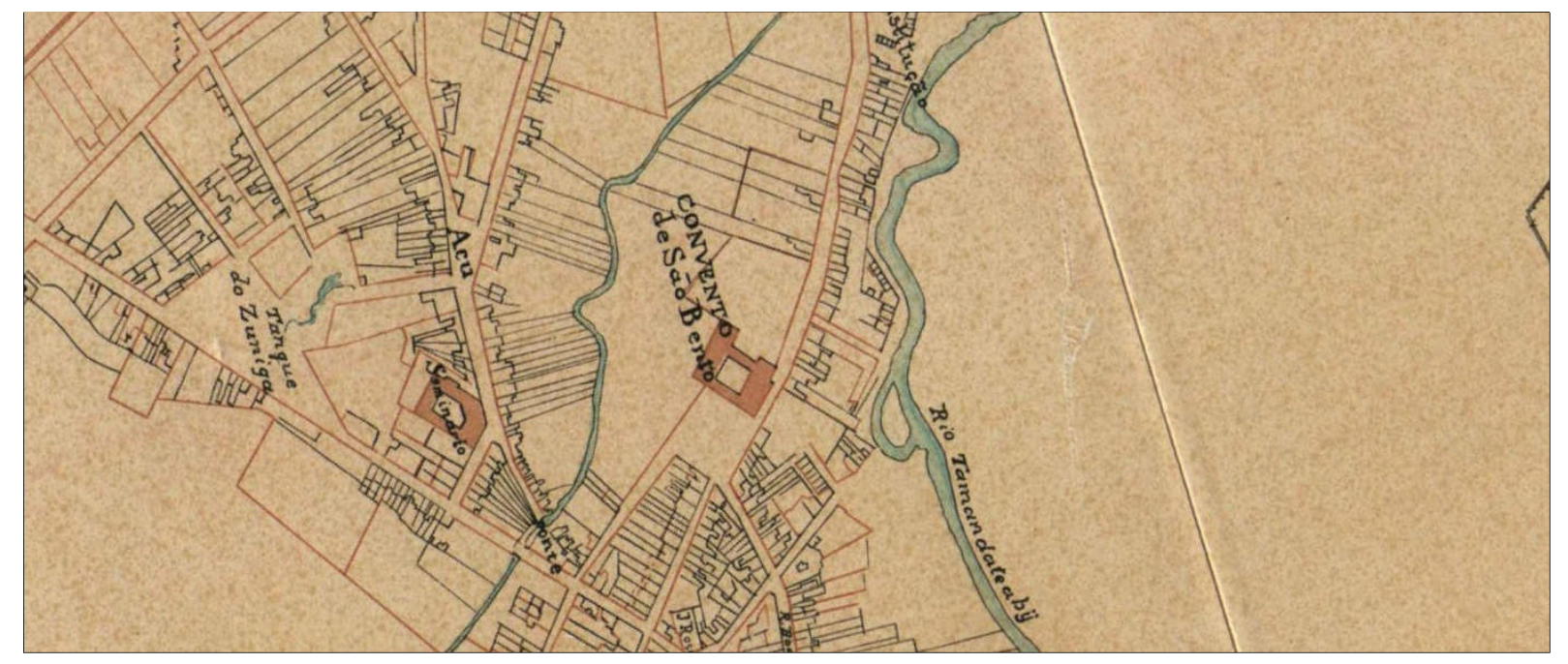

Figura 3_detalhe do mapa "MAPPA DA CIDADE DE SÃO PAULO E SEUS SUBURBIOS de C. A. Bresser - 1844/47"

Na figura 3 acima é possível visualizar os detalhes do mapa como nome do rio, dos edifícios e da ponte e o desenho das quadras e das ruas. Esse tipo de visualização é importante quando se trabalha com os detalhes do mapa.

A segunda etapa do trabalho consiste em georeferenciar a imagem do mapa escolhido através do uso de um mapa-base e de pontos de controle ${ }^{23}$. No caso deste estudo, foi escolhido um mapa-base da cidade de São Paulo para atribuir as referências geográficas e de projeção aos mapas históricos, numa tentativa de uniformizar as referências espaciais.

A figura 4 mostra a distribuição dos pontos de controle utilizados no georeferenciamento do mapa histórico.

23 "Pontos de controle" são arquivos-texto que armazenam as coordenadas da imagem digitalizada (georeferenciada) a partir de um mapa com referências espaciais ou a partir da entrada manual dos dados. 


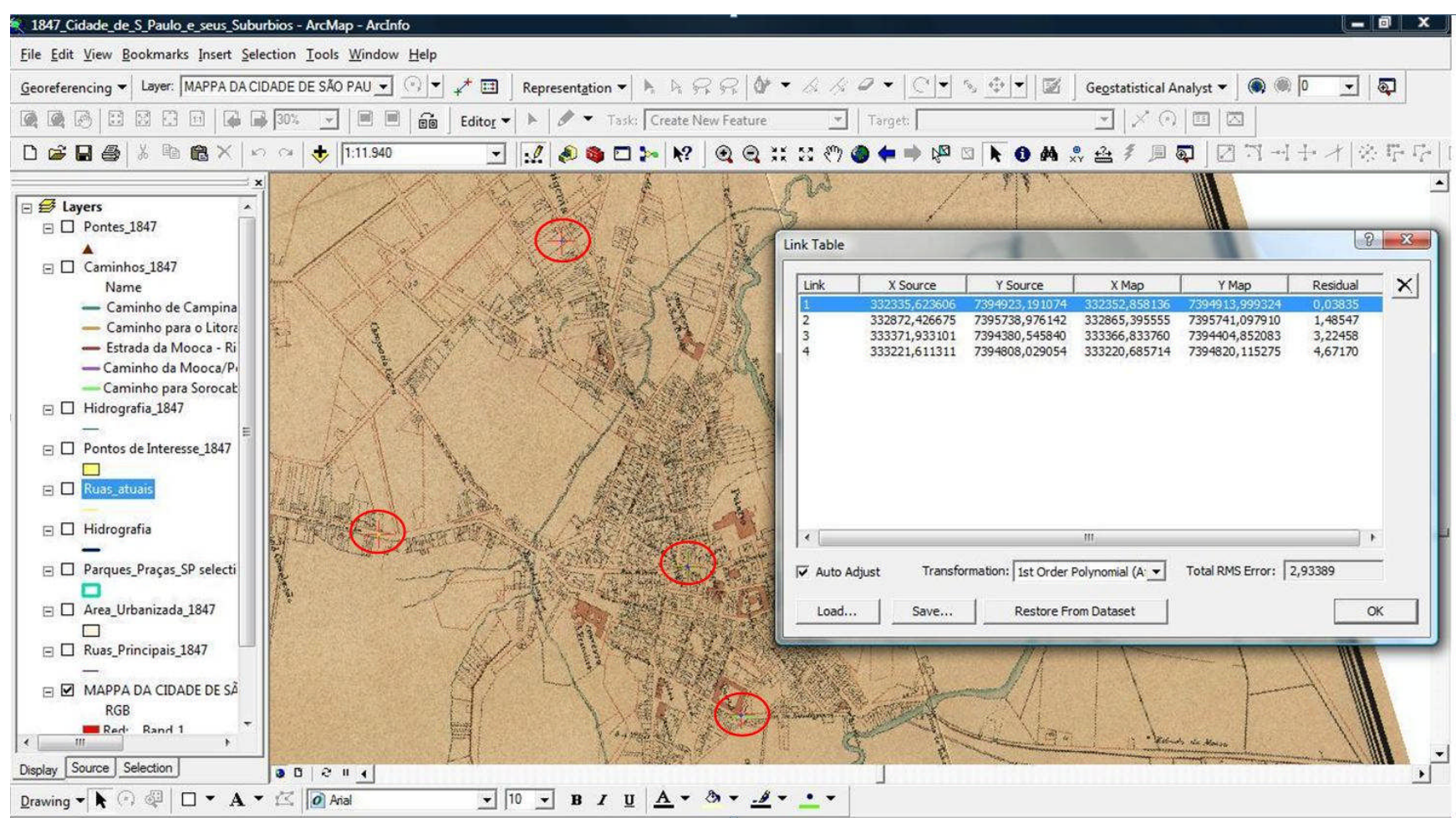

Figura 4_Pontos de Controle utilizados no georeferenciamento da imagem e tabela com as coordenadas dos pontos de controle. Visualizados no ArcGis 9.3

Nesse caso, foram adotados quatro pontos correspondentes com o mapa-base. $O$ mapa-base é o mapa da região metropolitana de São Paulo, com as características do sistema de coordenadas mostradas no quadro 2 abaixo.

Quadro 2_CARACTERÍSTICAS DO MAPA BASE UTILIZADO PARA 0 GEOREFERENCIAMENTO. Mostra o sistema de coordenadas e projeção, unidade de medida, sistema de coordenadas geográficas, Datum, Meridiano e unidade de medida angular do mapa utilizado como base para georeferenciar os mapas históricos analisados no estudo.

Projected Coordinate System: WGS_1984_UTM_Zone_23S

Projection: Transverse_Mercator

Linear Unit: Meter

Geographic Coordinate System: GCS_WGS_1984

Datum: D_WGS_1984

Prime Meridian: Greenwich

Angular Unit: Degree 
A figura 5 mostra o mapa-base utilizado no georeferenciamento de todas as plantas analisadas. O ArcGis utiliza ao mesmo tempo o sistema de coordenadas geográficas como o sistema de coordenadas projetadas, executando uma transformação na imagem georeferenciada para que haja um ajuste visual dela ao mesmo sistema de coordenada e escala do mapa adotado como base. Essa transformação para ajuste realizada no ArcGis provoca uma pequena distorção na imagem, fato que na maioria dos casos não interfere no trabalho de análise final.

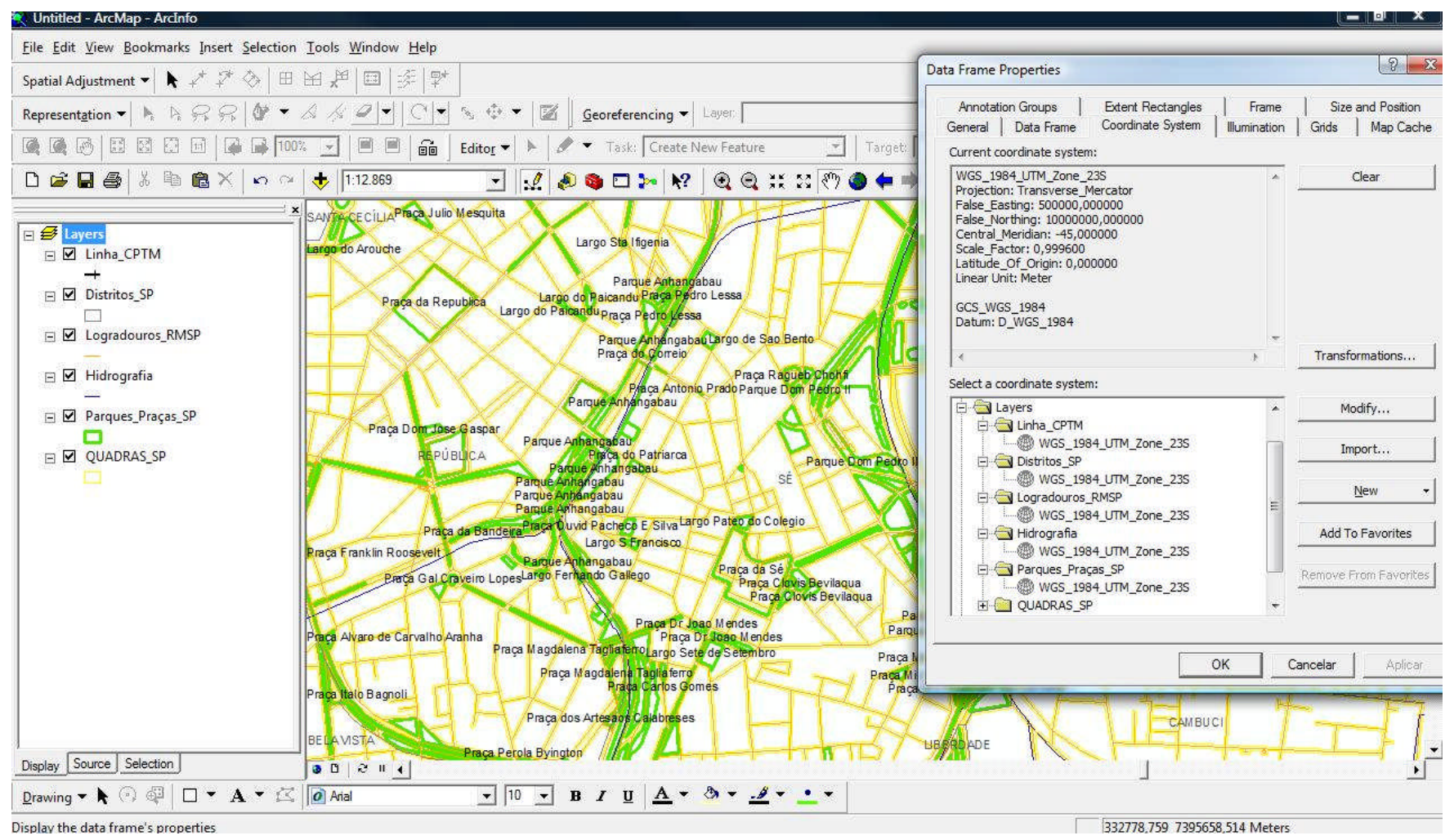

Figura 5_Mapa utilizado como base para o georeferenciamento dos mapas históricos. Mapa Base de São Paulo detalhe do centro da cidade 2005.

Fonte: HIDROGRAFIA : EMPLASA, 1980, "SCM - SISTEMA CARTOGRÁFICO METROPOLITANO" 1:10.000, REVISADO. LOGRADOUROS E PARQUES: DIGIBASE, 2005, BANCO DE DADOS GEOGRÁFICO DIGITAL DA RMSP.

A tabela de georeferenciamento do ArcGis apresenta as coordenadas dos pontos de controle no mapa-base (Source) e os pontos de controle do mapa georeferenciado (Map), além do valor residual, também chamado do $\mathrm{RMS}^{24}$. Nos valores residuais

\footnotetext{
${ }^{24}$ RMS - (root mean square error) É a medida da diferença entre os locais que são conhecidos e os locais que foram interpolados ou digitalizados. Erro RMS é obtido pelo quadrado das diferenças entre pontos conhecidos e desconhecidos, somando-os e dividindo-se pelo número de pontos de teste, e,
} 
mais baixos, o registro da imagem tende a ser mais preciso ${ }^{25}$, mas isso também vai depender da boa qualidade e da escolha dos pontos de controle, que devem ser, no mínimo, três. A figura 6 mostra a tabela de georeferenciamento gerada pelo mapa de 1877 , com um RMS baixo.

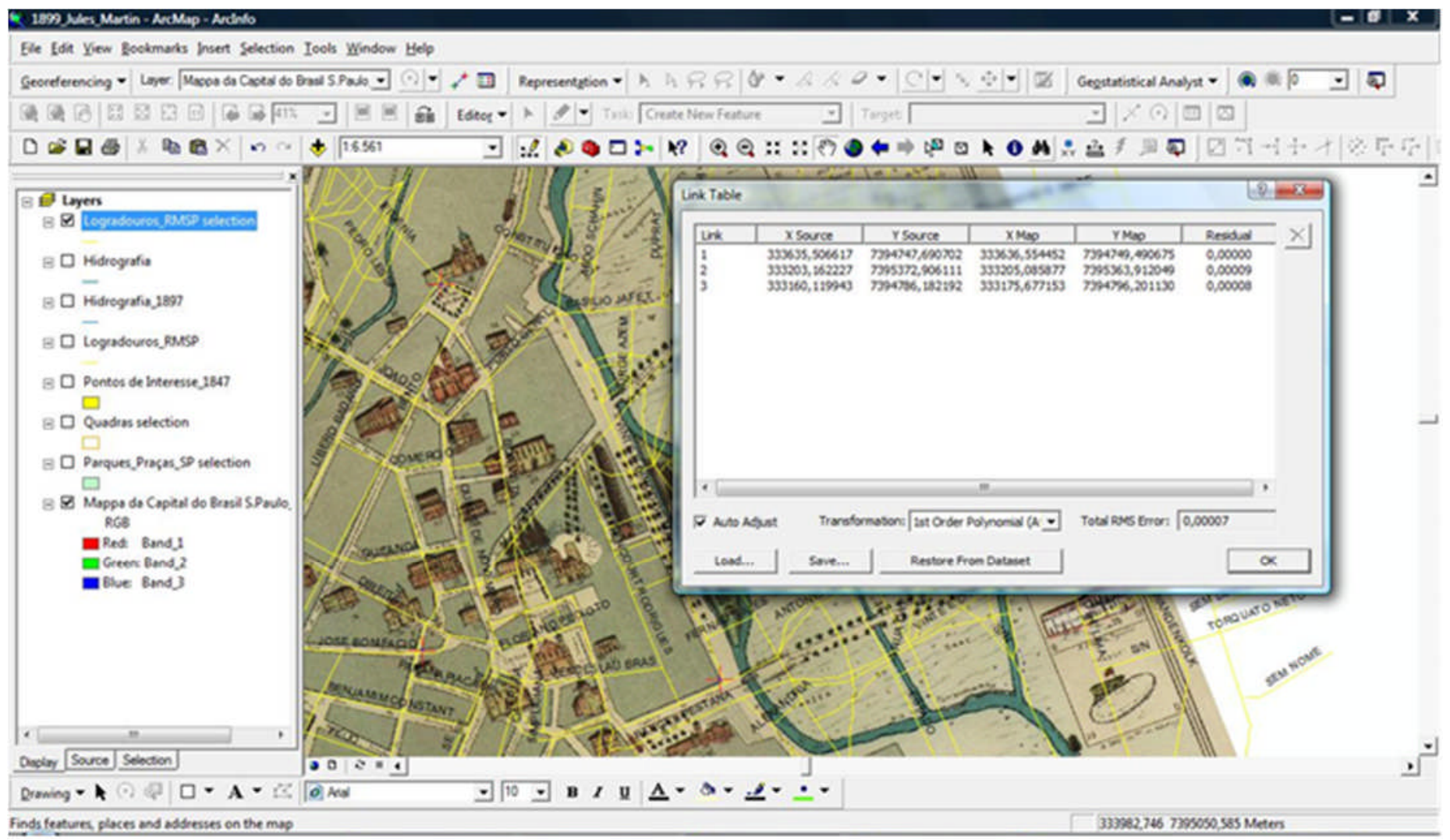

Figura 6_Tabela com RMS dos pontos de controle para o "Mappa da Capital do Brasil S.Paulo 1877". Mostra a tabela com pontos de controle de georeferenciamento e valores residuais baixos.

Após a distribuição dos pontos de controle no mapa histórico, o sistema realiza sua transformação. Através de sua rotação, observada na figura 7 a seguir, a sua orientação é ajustada ao mapa-base, mantendo assim, com pequena distorção, legíveis suas características essenciais, o traçado das ruas e dos edifícios, os nomes e a hidrografia.

em seguida, tomando a raiz quadrada do resultado.

Fonte:http://support.esri.com/en/knowledgebase/GISDictionary/term/RMS\%20error

${ }^{25}$ Uma opção para o registro é fazer uso de múltiplos pontos dez, por exemplo, e excluir os de valores residuais mais altos. 


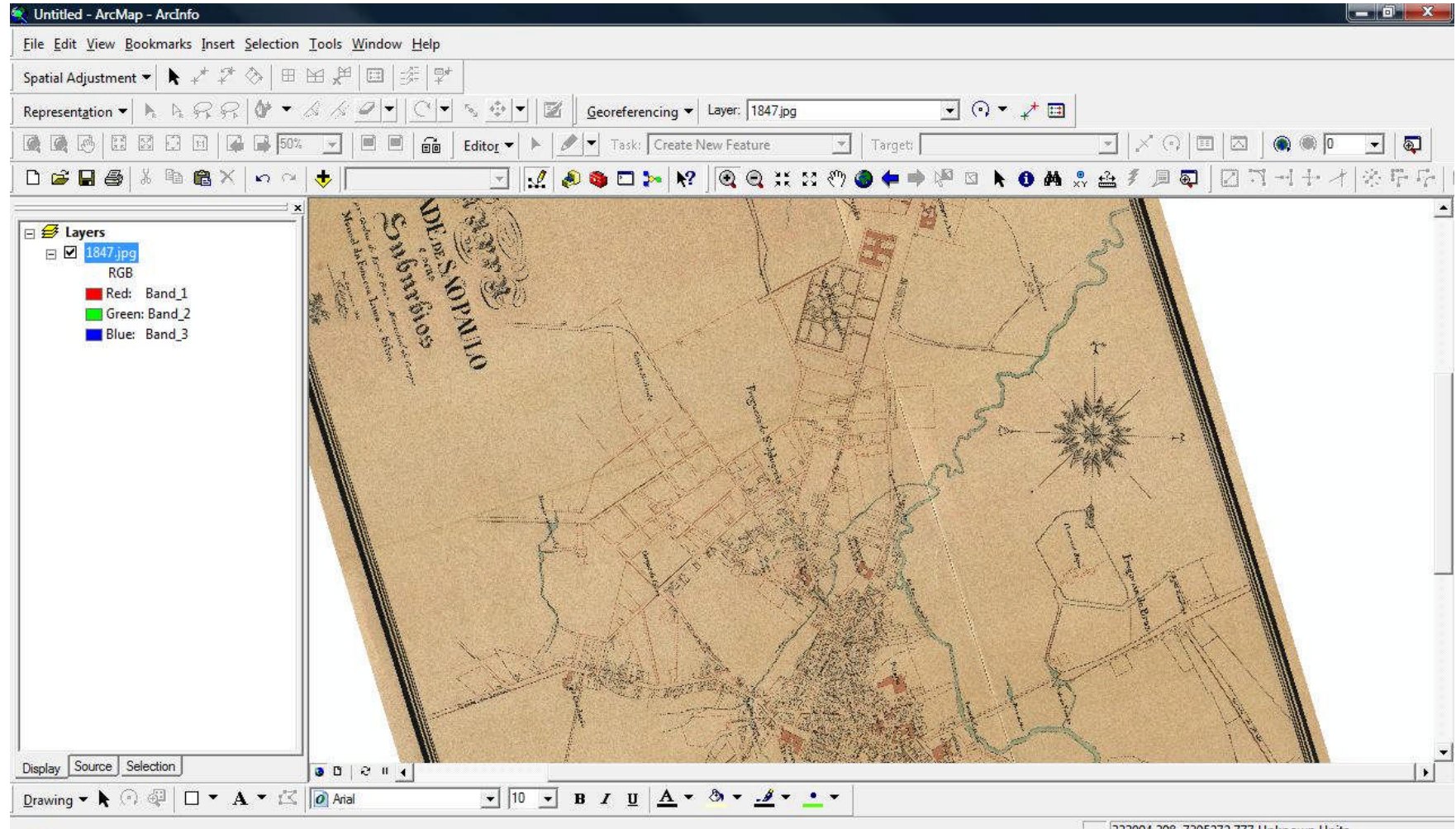

Figura 7_Mapa após georeferenciamento, com eixo em rotação e orientado para o Norte. Visualizado no ArcGis 9.3.

Esse processo de georeferenciamento da imagem raster, no caso, do mapa histórico, permite a comparação, a separação e a sobreposição dos dados geográficos entre diferentes mapas, possibilitando a análise comparativa dos mapas de forma dinâmica através da sobreposição das camadas de informações extraídas de diversos mapas, resultado que será mostrado no capítulo 8. 


\section{Proposta de Aplicação da Cartografia digital em Mapas históricos}

Neste capítulo, serão abordados os aspectos do uso da cartografia digital em mapas históricos através da apresentação das funcionalidades dos Sistemas de Informação Geográfica ou SIG.

A seguir será feita a análise dos mapas utilizados neste estudo, baseada no método apresentado no item 6.2.

O mapa 8 apresentado neste capítulo é a base cartográfica que foi utilizada nos estudos comparativos da "Planta Geral da Capital de São Paulo", organizada sob a direção do Dr. Gomes Cardim, em 1897, com escala de 1:20.000. Analisando a referida planta, (SIMONI, 2009)salienta: “(...) é uma representação de um momento singular na história e captura, em um sentido peculiar, o fluxo intenso de mudanças decorrentes de políticas que impulsionaram o processo migratório, a abolição jurídica da escravidão, a proclamação da República e as reformas institucionais do novo regime que antecederam sua elaboração".

\subsection{A Cartografia Digital como instrumento de análise}

A cartografia digital ou cartografia assistida por computador baseia-se na utilização de softwares para elaboração, tratamento e análise das informações geográficas ${ }^{26}$. Para elaboração e tratamento de mapas assistidos por computador, existem diferentes tipos de softwares que podem ser utilizados, desde os mais simples, como editores de imagens, que irão tratar da qualidade, da cor, do tamanho e da editoração do mapa, até softwares mais completos, que permitem tanto armazenamento e gerenciamento dos dados em um banco de dados, como análise e editoração; estes são os chamados Sistemas de Informação Geográfica, ou SIGs. No contexto da Geografia e da Engenharia, servem também para análise e tomada de decisões a respeito de problemas e situações que envolvem variáveis geográficas. E ainda, como apontado por (PÉREZ MACHADO, 2000, p. 1), os Sistemas de Informações Geográficas (SIGs) "se apresentam como instrumentos

\footnotetext{
${ }^{26}$ Entende-se por "informação geográfica" a representação de um objeto ou fenômeno localizável na superfície terrestre em um dado momento. (DENĖGRE \& SALGÉ, 2004)
} 
modernos do meio técnico-científico passíveis de serem aplicados ao estudo e entendimento do fenômeno da urbanização, suas causas e consequências." No presente estudo, optamos por utilizar um SIG em função da possibilidade de que os dados extraídos dos mapas históricos pudessem ser armazenados, manipulados e analisados em um mesmo ambiente computacional. Para a pesquisa, optou-se pelo uso do SIG ArcGIS, da empresa Esri, na versão 9.3.1. A escolha deu-se por motivo de adaptação ao uso do software e principalmente pelas ferramentas de análise espacial nele disponíveis.

Os SIGs funcionam de modo a armazenar os atributos do dado espacial em um banco de dados no formato linha/coluna, em que cada linha está relacionada com as referências espaciais do dado, ou seja, sua localização $(x, y)^{27}$ sobre a terra; e associados a essa informação, ainda temos outros atributos que podem ser inseridos em colunas, no mesmo banco de dados, como nome (ou qualquer outra informação no formato de texto), extensão do fenômeno (como, por exemplo, área ocupada) e dados quantitativos (como população local).

$\mathrm{Na}$ definição de SIG proposta por (GREGORY \& ELL, 2007), os autores descrevem as funcionalidades desse tipo de software da seguinte maneira: "as principais capacidades do SIG: ele permite que uma base de dados geográfica seja criada, e os dados nela contidos sejam manipulados, integrados, analisados e visualizados." (Trad. nossa)

(BURROUGH and MC DONNELL 1998) apresentam a seguinte definição de SIG"um poderoso conjunto de ferramentas para coletar, armazenar, recuperar, transformar e exibir dados espaciais do mundo ${ }^{28}$ (trad. nossa) As definições citadas apresentam o SIG principalmente como uma ferramenta para manipular as informações geográficas de modo a armazená-las em um banco de dados, e, a partir delas, elaborar um produto cartográfico que corresponda às necessidades do usuário.

Os autores (GREGORY \& ELL, 2007) também lembram que, para realizar as operações acima descritas, ou seja, a abordagem de um SIG, não se faz necessário estritamente o uso do software, porém, seu uso é vantajoso em termos de tempo e resultados.

\footnotetext{
${ }^{27}$ (BURROUGH and MC DONNELL 1998). Refere-se, no caso de dados da superfície terrestre, às coordenadas geográficas, que podem ser Norte/Este ou Longitude/Latitude, em função da aplicação. 28 "a powerful set of tools for collecting, storing, retrieving at will, transforming and displaying spatial data from the real world."
} 
Os benefícios de se fazer uso dos SIGs podem ser enumerados da seguinte forma: a organização das fontes históricas, a capacidade de visualizar recursos, os resultados obtidos a partir do cruzamento de informações e a possibilidade de executar análises espaciais sobre os dados inseridos. Com relação ao tempo de execução dessas tarefas, uma vez que as informações já estão no banco de dados, é possível realizar diferentes análises em pouco tempo, assim como ter uma resposta visual (em forma de mapa) de tais análises.

Uma informação geográfica, ou dado geográfico, possui dois componentes principais: o atributo que define o objeto (o quê) e a localização, que diz onde está esse objeto. Há também, na maioria dos casos, o componente temporal.

Para expressar a informação geográfica por meio de sistemas informatizados, foram desenvolvidos dois modelos numéricos de dados: o modelo vetor e o modelo raster. (DENÈGRE \& SALGÉ, 2004)

No modelo de dado vetorial, a geometria do dado geográfico é descrita por pares de pontos coordenados ( $\mathrm{x}$ e $\mathrm{y}$ ), que podem compor três tipos básicos de figuras correspondentes a objetos no mundo real: ponto, linha ou polígono. Por exemplo: uma linha de bondes pode ser representada por uma cadeia de pontos conectados; estações de trem podem ser representadas por pontos; e bairros, por polígonos. Com o modelo vetorial de dados é possível criar as relações topológicas entre as entidades representadas ${ }^{29}$.

O modelo de dado raster, também chamado de "matricial", é um modelo baseado numa lógica de varredura de pixels (pontos que formam a imagem na tela do monitor, no computador), compondo uma imagem. Esse é o modelo de dado utilizado quando uma imagem é obtida através de câmera digital ou scanner, ou seja, essa imagem inicialmente não possui a referência espacial das coordenadas $(\mathrm{x}, \mathrm{y})$. Esse tipo de modelo é utilizado para representação de variáveis contínuas no espaço sem limites e em localizações precisas como, por exemplo: relevo, temperatura ou até, em alguns casos, o uso da terra.

O Quadro 3 (PÉREZ MACHADO, Sobreposição da cartografia digital vetorial às cartas e mapas históricos da Cidade, 2010) apresenta uma tabela ilustrativa das

\footnotetext{
29 "Entidade" é definida por (BURROUGH and MC DONNELL 1998) como "objeto", e é descrita por seus atributos ou propriedades, e possui coordenadas $(X, Y)$ para fins de sua localização. Uma entidade pode ser uma casa, um rio, uma floresta, uma estrada, entre outros objetos representáveis.
} 
principais características dos Sistemas de Informação Geográfica, de acordo com o modelo utilizado. O autor destaca que a tabela é meramente orientadora.

\begin{tabular}{l|l|l}
\hline \multicolumn{3}{c}{ Sistemas de Informação Geográfica } \\
\hline Modelo DADo Grifico & \multicolumn{1}{|c}{ MATRICLAL } & \multicolumn{1}{c}{ VETORLL } \\
\hline Com base em & Células (imagens) & Vetores (redes) \\
\hline Possibilidade de fluxos & Pouca & Sim \\
\hline Aplicação mais comum & Meio ambiente e Rec. Nat. & Topografia e cadastros \\
\hline Alcance territorial & Regional, nacional & Local, urbano \\
\hline Grau de detalhe possível & Menor & Maior \\
\hline Estética cartográfica & Pior (com baixa resolução) & Melhor \\
\hline Escalas mais utilizadas & Menores que 1:50.000 & Maiores que 1:50.000 \\
\hline Custo implantacão $\left(\mathrm{km}^{2}\right)$ & Relativamente baixo & Relativamente alto \\
\hline Tempo implantação $\left(\mathrm{km}^{2}\right)$ & Menor & Maior \\
\hline
\end{tabular}

Quadro 3_Características Principais dos Sistemas de Informação Geográfica, segundo modelo de dados gráfico utilizado (Elaboração Reinaldo P. Pérez Machado, 2010)

Os atributos das entidades, ou dos objetos representados, assim como suas respectivas informações espaciais, são armazenados em uma tabela no banco de dados e representados através de camadas temáticas chamadas de layers ${ }^{30}$ (ou "camadas"). Normalmente, um mapa temático é composto por vários layers (por exemplo, hidrografia, ruas, ferrovias).

(GREGORY \& ELL, 2007) ${ }^{31}$ destacam o uso dos layers: "O poder real das camadas não advém da capacidade de representar um único mapa, vem da capacidade de integrar dados de diferentes fontes." (Trad. Nossa). Os layers assinalam a possibilidade de integração das informações advindas de diferentes bases de dados, favorecendo a elaboração de mapas mais complexos e explicativos.

A aquisição de dados geográficos para construção do banco de dados de um SIG pode ser feita de vários modos: recuperação de dados provenientes de sites especializados como, por exemplo, o IBGE, no Brasil; download de imagens de mapas históricos nas bibliotecas; entrada de dados feita manualmente; digitalização de mapas por meio de scanners ou fotos, e outros.

\footnotetext{
${ }^{30}$ Ao se construir um layer, escolhe-se um tipo de atributo a ser representado por linha, por ponto ou por polígono; em geral, cada layer possui apenas um tipo de atributo.

${ }^{31}$ Versão do livro em formato Kindle sem numeração de páginas.
} 
Os SIGs possuem um grande número de funcionalidades/ferramentas para manipulação dos dados adquiridos. São principalmente as ferramentas de análise espacial que possibilitam a criação de mapas temáticos analíticos como resposta aos questionamentos propostos nos estudos do território.

As principais questões sobre um determinado território que podem ser respondidas pelos SIGs foram caracterizadas por (DENĖGRE \& SALGÉ, 2004), e são:

- Onde o fenômeno, ou objeto, está?

- O quê? (essa questão refere-se ao inventário das entidades presentes e seus atributos).

- Como? Quais relações existem entre as entidades ou objetos (análise espacial)?

- Quando? Qual o momento das mudanças? Qual a idade dos objetos? (análise temporal).

- E se? (essa questão refere-se à produção de cenários e mudanças).

Para responder a essas questões, os SIGs oferecem um conjunto de ferramentas de análise espacial; dentre essas, destacam-se, no estudo de mapas históricos, as operações de sobreposições de camadas (overlay), georeferenciamento, cálculos com base na geometria dos objetos, consulta (query) e análise de proximidade utilizando as ferramentas de criação de buffers (análise espacial de proximidade, adjacência, inserção ou inserção) e de polígonos de Thiessen, assim como operações ainda mais sofisticadas de estatística espacial (geoestatística).

As operações chamadas de "sobreposições de camadas" (overlay) são muito úteis na criação de mapas temáticos e nos estudos comparativos. Cada camada, ou layer, representa um conjunto de atributos com a mesma geometria, os quais são armazenados em uma tabela. Tal conjunto é chamado, no ArcGis, de feature class, ou "classe de feição". Pode-se criar um mapa que mostre estradas, fábricas e bairros através da sobreposição dessas três camadas de informação para analisar, por exemplo, o deslocamento dos operários de suas casas até a fábrica usando os caminhos existentes.

Por meio das sobreposições também é possível visualizar os conjuntos de características que se sobrepõem como, por exemplo, as estações de trem que estão dentro da área de um bairro, ou os rios que cruzam a área urbana. Na prática, (PÉREZ MACHADO, 2010) ressalta o recurso dos SIGs: 
Um dos recursos mais atraentes dos Sistemas de Informação Geográfica - SIG é a possibilidade de integração, no mesmo espaço geográfico, de imagens e vetores na forma de pontos, linhas ou áreas, ou seja, de colocar capas superpostas de dois modelos de dados gráficos diferentes, o matricial e o vetorial.

A possibilidade apresentada por Machado mostra-se totalmente compatível no trabalho com mapas históricos, pois permite visualizar, a um só tempo, o mapa original e, sobrepostas a ele, novas camadas de informações.

O georeferenciamento de uma imagem, ou de um mapa, é uma operação que consiste em atribuir dados referentes às suas coordenadas geográficas $^{32}$ e à projeção $^{33}$. Para que as camadas sejam sobrepostas, é necessário que possuam as mesmas referências espaciais. No caso de mapas históricos, há uma grande variação das coordenadas e das projeções, e isso está relacionado com a data em que o mapa foi elaborado e com a opção feita pelo cartógrafo.

Os cálculos de área, perímetro, comprimento, coordenadas $\mathrm{x}$ e y e centróides ${ }^{34}$ das coordenadas podem ser realizados diretamente nas tabelas que compõem as camadas, e podem ser divididos de acordo com a geometria dos objetos.

Pode-se também calcular o centróide x e y das linhas e dos polígonos. A conversão de polígonos em pontos, através da ferramenta "Feature to Point", transforma polígonos em pontos localizados no centróide do polígono, tornando possível a criação do layer com os centróides dos polígonos representados. Um exemplo seria achar o centróide dos bairros permitindo outros cálculos no uso desse dado, assim como efetuar análises de proximidade e distância média percorrida pelos moradores do bairro até a estação de bonde, ou de trem, mais próxima.

A consulta (query) consiste em buscar os atributos de interesse do usuário em determinada camada de modo a segregá-los por meio da seleção, que pode ser feita

\footnotetext{
32 "É com base em determinados sistemas de coordenadas que descrevemos geometricamente a superfície terrestre nos levantamentos... Para o elipsóide, ou esfera, usualmente empregamos um sistema de coordenadas cartesiano curvilíneo (longitude e latitude, ao longo de paralelos e meridianos, respectivamente). Para o plano, um sistema de coordenadas cartesianas $\mathrm{X}$ e $\mathrm{Y}$ é usualmente aplicável, correspondendo a coordenadas Este e Norte" (cf. IBGE 1999).

${ }^{33}$ A projeção cartográfica é a operação matemática e gráfica que possibilita a representação da Terra em um plano. Ao longo dos anos, o modo como essas projeções são feitas evoluiu muito, e por esse motivo temos vários tipos de projeções cartográficas.

${ }^{34} \mathrm{O}$ centróide, ou centro médio, é a média das coordenadas $\mathrm{x}$ e y de um polígono, seu centro de massa.
} 
diretamente na tabela ou visualmente na camada, clicando nos atributos de interesse. Um exemplo do uso da query é buscar, dentro do polígono que representa a área urbanizada de uma cidade, elementos como cemitérios, fábricas, estações e, a partir daí, criar uma nova camada apenas com os elementos selecionados.

A análise de proximidade responde a questões das relações existentes entre os objetos e seus atributos; a ferramenta buffer permite construir polígonos ao redor de pontos, em torno de outros polígonos ou de linhas. A criação de buffers pode ser feita para o estudo de áreas de influência de um determinado fator. Por exemplo pode se criar um círculo com raio de 3 ou 5 quilômetros em torno do centróide de um bairro.

Outra forma de efetuar análises de proximidade com o SIGs é utilizar a construção de polígonos de Thiessen ou Voronoi. Tais polígonos são modelos de interpolação que utilizam como base as redes triangulares. (CINTRA, 1985) descreve a sequência da construção desses modelos da seguinte forma: geração da malha triangular a partir das coordenadas dos pontos fornecidos, esquemas de interpolação, modelo de rede discreta e aplicativos (a fase da visualização) e, por fim, aplicação do modelo definido. No ArcGIS, a ferramenta "Create Thiessen Polygons" executa a operação automaticamente, construindo os processos de triangulação, interpolação e construção do modelo através da entrada de pontos. Através dessa ferramenta é possível inferir áreas de influência por proximidade, ou seja, cada polígono corresponde à área de influência máxima de um ponto.

Sobre a importância da utilização dos SIGs nos estudos com mapas históricos, (RUMSEY, 2002, p. 2) destaca que o "GIS traz um novo fôlego para mapas históricos, libertando-os dos confins da sua forma estática de impressão original. Isso também possibilita um novo nível de compreensão." (trad. nossa)

\subsection{A análise dos mapas utilizados na pesquisa}

A seguir são analisados de forma individual os mapas selecionados para este estudo. Para cada mapa, a tarefa inicia-se pela junção do primeiro com o segundo nível de representação cartográfica, numa análise cartográfico-iconográfica ${ }^{35}$,

\footnotetext{
${ }^{35}$ Para este estudo alguns nomes serão grafados conforme a escrita no mapa original.
} 
conforme a adaptação de Panofsky proposta no item 6.2. Em seguida, é feita uma análise iconológica, levando-se em consideração os aspectos assinalados por (BUENO, 2009): uso de símbolos convencionais exacerbados, ênfases gráficas, centralidades criadas, linhas abstratas, distorções intencionais, ausência de registro, ausência de topônimos, e outros. As análises cartográficas seguem por analogia a proposta de itens destacados por (CINTRA, 2009), ou seja, estão focadas nos seguintes aspectos do mapa:

-Autoria: breve descrição do autor do mapa ou da cópia, conforme o caso.

-Escala, Orientação e Pontos de Referência: a escala é a relação entre a medida real de um objeto e sua representação no mapa; pode ser numérica ou gráfica. A orientação do mapa refere-se basicamente à posição do Norte do mapa, ou seja, se o mapa possui uma indicação gráfica de orientação (como seta para o norte ou rosa dos ventos). Já os pontos de referência são os elementos no mapa como rios, edifícios, ruas ou parques conhecidos que podem indicar a sua orientação ou mesmo auxiliar na comparação com outros mapas.

-Cores, convenções cartográficas, símbolos e outros detalhes: nesse item, são descritas as cores utilizadas no mapa e as convenções cartográficas como, por exemplo, as representações de ruas, rios, edifícios e outros elementos que constam no mapa, além de outros detalhes particulares a cada mapa.

Nos estudos sobre a cidade de São Paulo, alguns autores já apresentaram descrições detalhadas sobre os mapas pertencentes ao álbum de plantas históricas São Paulo Antigo: Plantas da Cidade, publicado em 1954 pela Comissão do IV Centenário. Destacamos (CAMPOS E., 2008), (CINTRA, Plantas Históricas, 2004) e (REIS, 2004), trazendo este último um apêndice comentando os mapas da cidade de São Paulo e o acervo em que foram localizados.

Um levantamento de plantas da cidade foi feito mais recentemente por (GOUVÊA, 2010); em sua dissertação de mestrado, são analisadas plantas produzidas entre 1841 e 1954. 


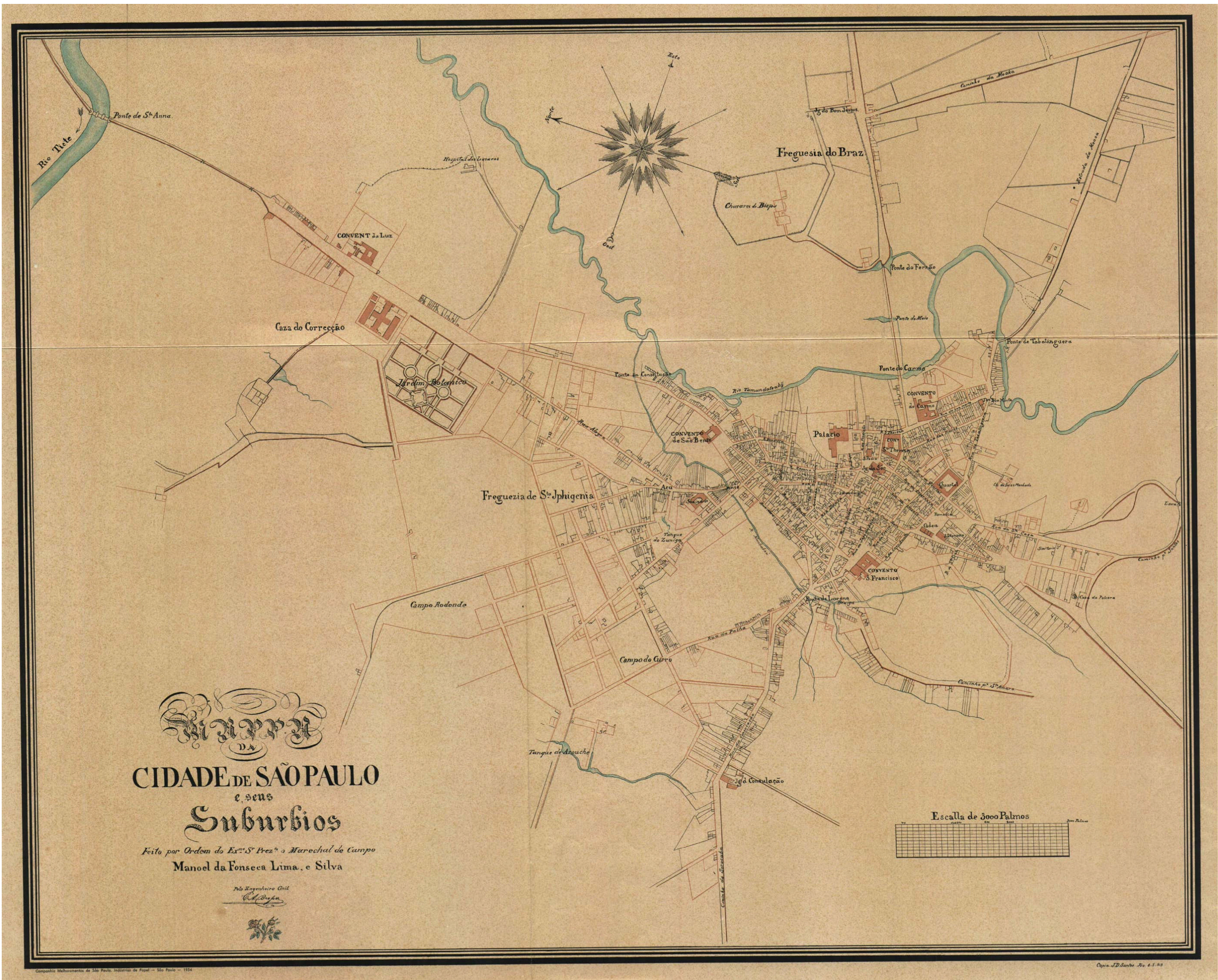

Mapa 2 MAPPA DA CIDADE DE SÃO PAULO E SEUS SUBURBIOS- 1844/47 - C. A. Bresser Cópia reproduzida em 1918 Fơnte: (São Paulo (SP). Comissão do IV Centenário da Cidade, 1954) 


\section{a) Análise cartográfico-iconográfica}

Autoria. A planta apresentada (mapa 2) é uma reprodução publicada no álbum de plantas históricas São Paulo Antigo: Plantas da Cidade (São Paulo (SP). Comissão do IV Centenário da Cidade, 1954). O autor da planta original foi Carlos Abrão Bresser conforme aparece grafado na parte inferior esquerda do mapa, agrimensor prussiano que veio para São Paulo trabalhar com Daniel Pedro Müller, primeiro diretor de Obras Públicas da Província de São Paulo, em 1838 (UNZELTE, 2003). Não há referência de data, mas a data de execução estimada por (CAMPOS, São Paulo antigo: plantas da cidade, 2008) é entre $1^{\circ}$ de maio de 1844 e 5 de novembro de 1847; (CINTRA, 2004) inclina-se para o ano de 1847. Outro detalhe sobre autoria é que há uma nota ao pé da planta, à direita: Copia de J. D. Santos Rio. 8 - 5-919.

Escala, Orientação e Pontos de Referência. Há uma indicação de escala no canto esquerdo do mapa: "escala de 3000 palmos". Uma rosa dos ventos desenhada na parte superior do mapa aponta para o Norte em direção à margem esquerda da folha. Esse mapa está orientado para o Leste.

\section{Cores, convenções cartográficas símbolos e outros detalhes.}

A cópia aqui reproduzida aparece bem amarelada. As ruas e os quarteirões são representados pela cor marrom. Os edifícios dos conventos do Carmo, Sta. Tereza, S. Francisco, São Bento e da Luz, o Quartel, a Cadeia, o Palácio, o Seminário e a Casa de Correção são destacados dos demais elementos representados pela tonalidade marrom com que são preenchidos seus contornos.

Nesse mapa, é possível reconhecer, através do desenho e dos nomes, os caminhos de saída da cidade desenhados a partir do fim da área urbanizada como uma linha marrom reforçada. Esses caminhos são grafados da seguinte forma:

1. Caminho p. ${ }^{a} S .{ }^{\text {to }}$ Amaro na direção sul

2. Caminho da Mooka [sic] na direção leste

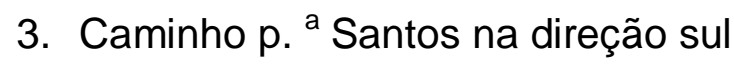

4. Caminho de Sorocaba na direção Oeste continuação da Rua da Consolação. O mapa mostra quatro pontes sobre o Rio Tamanduateí: de Tabatinguera, Carmo, do Ferrão e do meio. Sobre o Rio Anhangabaú, grafado como "R. Nanhabaú" [sic] estão a ponte da Constituição, uma ponte sem nome próxima ao Seminário e a ponte do Lorena. A ponte de Sta. Anna aparece sobre um trecho do Rio Tietê, no canto superior esquerdo do mapa. 
Os rios são representados de modo convencional em azul, com um traço simples ou com duas margens. No pequeno trecho representando o Rio Tietê, na margem superior esquerda do mapa, há uma seta indicando seu sentido para o Oeste.

A respeito da importância dessa planta, (CINTRA, 2004, p. 78) destaca: "São desenhados os lotes (limites dos terrenos) e as edificações e, por esse fato, Bresser, por essa planta ou pela de 1841, pode ser considerado o introdutor da planta cadastral da cidade." Ainda sobre a natureza dessa planta, é possível ver nitidamente sua natureza cadastral em função dos desenhos de casas e de edifícios públicos que aparecem nessa reprodução.

Se comparada com a planta elaborada por Bresser em 1841, esta parece ser uma versão mais artística, como assevera (CINTRA, 2004, p. 78): "O veio artístico revelase no título do mapa, na bela rosa dos ventos e no pequeno ramo de rosas abaixo da assinatura do autor."

\section{b) Análise iconológica}

O tema primário desse mapa é a representação da cidade de São Paulo na metade do século XIX. A identidade do lugar representado é reconhecida pelo título do mapa

e por seus elementos representados, pelos principais rios Anhangabaú e Tamanduateí, que primordialmente delimitavam o contorno de São Paulo, pelas duas freguesias, representadas no mapa, de Santa Efigênia e do Brás, e pelos conventos que, em conjunto, fazem parte da evolução histórica da cidade. A datação do mapa foi tomada, como explica (CINTRA, 2004), a partir da comparação com outros mapas produzidos pelo autor que o assina, e também pela dedicatória nele informada: "Feito por Ordem do Ex. ${ }^{\text {mo }} S^{r}$ Prez. ${ }^{\text {te }}$ o marechal de Campo Manoel da Fonseca Lima e Silva", o qual foi presidente da província de São Paulo entre 1844 e 1847; portanto, o mapa deve ter sido apresentado na mesma época.

Destacam-se nesse mapa da cidade de São Paulo a representação dos conventos, das igrejas e do seminário.

Edifícios públicos: quartel, palácio, Hospital dos Lázaros, cadeia, Jardim Botânico e casa de correção, grafada "Caza do Correcção" [sic], além de algumas pontes: do Ferrão, do Carmo, da Constituição, Tabatinguera, Lorena e Santanna. E dois tanques: do Arouche e do Zuniga. Chácaras: do Bispo e de Inez Machado, grafada 
como "do Inez Machado". Freguesias: apenas duas, grafadas como "Freguezia de

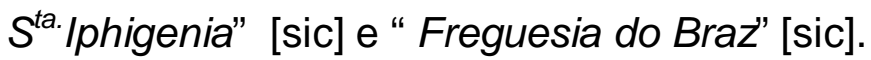

O conjunto desses elementos revela uma cidade sem limites bem estabelecidos, em processo de expansão, percebido pelo desenho de lotes "vazios" nas porções Leste e Oeste.

Através da observação dos detalhes das letras e de acabamentos do desenho, é possível inferir o esforço artístico do autor em demonstrar suas habilidades tanto artísticas como técnicas ao desenhar os lotes com suas respectivas edificações, unindo, assim, a técnica e a arte na representação da cidade.

Comparando esse mapa com outro produzido pelo autor, o "Mappa da cidade de São Paulo: offerecido a sua Magestade pelo Presidente da Provincia Manoel da Fonseca Lima e Silva", elaborado em data estimada de $1846^{36}$, percebe-se realmente a habilidade artística do autor e também o contexto de sua realização, tendo sido feito, nesse caso, especificamente para a visita do Imperador à província (ressalte-se que, em ambos os casos, os mapas foram feitos para o presidente da província; então se percebe que seriam mapas para fins do governo).

Esse mapa dá ênfase ao desenho das edificações que compõem o centro da cidade entre os rios; assim, é possível observar o adensamento urbano.

Há também os silêncios do mapa, ou "vazios": as porções do desenho que estão em branco, algumas com lotes grandes e vazios no seu interior, como na Freguesia do Brás e na região da atual Praça da República (Campo do Curro).

Se comparados com os do mapa de Carlos Rath, "Mapa da imperial Cidade de São Paulo" de 1855, os vazios, neste último, aparecem preenchidos por lotes.

Como já abordado na análise cartográfico-iconográfica, o mapa mostra os caminhos de saída da cidade; daí presume-se que esses caminhos cruzavam-se no interior da cidade, deixando seu centro marcado pela marcha das tropas de muares.

A respeito dos caminhos ainda remanescentes da época colonial, (BRUNO, 1954, p. 592) lembra: "Não só pelos caminhos como pelas ruas da cidade transitavam, no período de 1828 a 1872, as tropas de burro, os carros de boi e os cavaleiros."

${ }^{36}$ Data estimada segundo informações constantes na ficha catalográfica do mapa na Biblioteca Nacional. 
Segundo (MORSE, 1970, p. 43): "A chegada à cidade, por qualquer dessas estradas era determinada pela topografia, que por sua vez era função dos rios e afluentes e de seu efeito erosivo do solo argiloso o planalto."

As pontes são elementos que contribuem para a estruturação da cidade, dos caminhos e do trânsito já que, obrigatoriamente, não só as pessoas, mas também as tropas deviam passar por elas.

Através da análise desses caminhos, das pontes e de pousos ${ }^{37}$, poderia ser feito um mapa com o traçado do trajeto das tropas dentro da cidade, o que demonstraria uma grande atividade nessas vias de circulação.

${ }^{37}$ Em outros mapas, aparecem pousos no Largo do Bexiga, na Luz e em algum outro ponto; e, segundo (BRUNO, 1984), principalmente no Piques de onde irradiavam os caminhos de saída da cidade. 


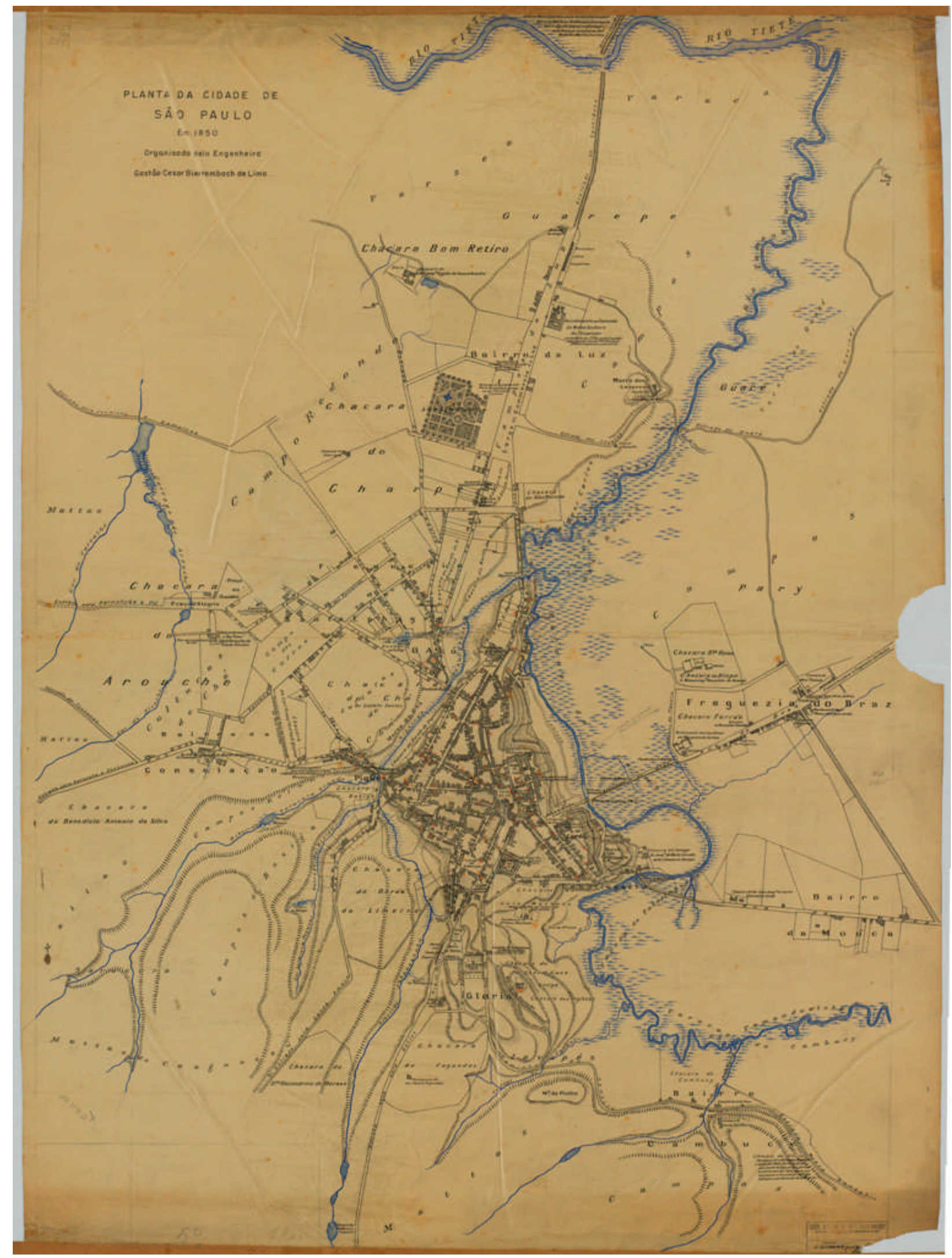

Mapa 3_Planta da Cidade de São Paulo Em 1850- Organizada pelo Engenheiro Gastão César Bierrenbach de Lima.

Fonte: Arquivo do Estado de São Paulo 


\section{a) Análise cartográfico-iconográfica}

Autoria. Mapa do acervo do Instituto Geográfico Geológico. Esse mapa procura refletir a situação da cidade em 1850 e, por comparação com outros, pode-se dizer que é um mapa fiel, nesse sentido, e que acrescenta algumas informações interessantes provenientes de fontes textuais. $O$ autor foi o engenheiro Gastão César Bierrenbach de Lima, que elaborou outras obras sobre a cidade de São Paulo, como o Dicionário geográfico do Estado de São Paulo, publicado em 1943, e o Guia geográfico das localidades do Estado de São Paulo, publicado em 1942. Assim, é possível inferir que esse mapa também tenha sido produzido na década de 40. Mas a situação que reflete é a da metade do século XIX e, por sua fidelidade como mapa-síntese, foi utilizado, com as devidas cautelas, na presente pesquisa.

Escala, Orientação e Pontos de Referência. Os principais pontos de referência são a posição dos rios Tietê, Tamanduateí e Anhangabaú. Pela data em que tal mapa foi feito, constata-se que a planta está orientada para o Norte.

Cores, convenções cartográficas símbolos e outros detalhes. Feito em papel vegetal, mostra os principais rios da cidade como o Tamanduateí, o Tietê, o Saracura Grande, o Anhangabaú e o Córrego do Bexiga na cor azul. As várzeas são representadas por tracejados em azul ao longo dos rios. Também estão representados os corpos de água e as colinas, as ladeiras e os morros da cidade, com tracejados em preto. Os morros e escarpas aparecem representados por linhas com hachuras internas para morros e hachuras externas para escarpas.

O autor representou as chácaras existentes em 1850, como também as principais ruas e caminhos. As ruas estão representadas em linha preta e contínua, ainda que existam algumas representadas em tracejado preto (indicando que se trata de projeto); os edifícios existentes estão hachurados em preto, dando a impressão de uma planta cadastral. Existe uma numeração em vermelho feita, principalmente, na área central da cidade, sobre edifícios, cruzamentos de ruas e praças, mas não há nessa folha uma legenda explicativa acerca dessa numeração. Há desenhos dos edifícios, das chácaras com os respectivos nomes de proprietários, das igrejas, das praças e dos conventos. As igrejas são representadas pela forma do prédio com uma cruz, e os cemitérios, com várias pequenas cruzes, na parte interna do desenho. 
Há notas explicativas sobre chácaras, bairros e edifícios situados nos diversos pontos dos mapas, e são indicadas as datas de construção dos edifícios, assim como as de reformas. Na parte norte da cidade, em direção ao atual bairro de Santana, há uma anotação sobre a origem do bairro. E há ainda anotações, feitas a lápis, com algumas datas e observações, talvez de acréscimos posteriores.

\section{b) Análise iconológica}

Este mapa teve provavelmente como finalidade um estudo histórico, resumindo e reunindo diversas fontes, tanto cartográficas como textuais; por isso, contém a representação dos elementos embrionários da expansão da cidade, as principais ruas e chácaras das quais se originaram loteamentos e jardins.

Trata-se de um mapa que tenta ser fiel ao período retratado, e para isso inclui várias notas explicativas sobre os elementos desenhados e uma numeração em vermelho, sobre edificações importantes para a qual não foram encontradas explicações.

As chácaras constituem um elemento diferencial desse mapa, pois outros só representam uma ou outra delas, e, ainda assim, esporadicamente. O mapa representa também as várzeas, com hachuras em azul. Estes dois temas, chácaras e várzeas, são elementos estruturantes do desenvolvimento da cidade, pois representam reservas de áreas e terrenos que seriam saneados, loteados e ocupados na expansão da cidade, condicionando também a direção dos alinhamentos das ruas.

A cidade no início do século XIX tinha seu núcleo central rodeado por chácaras como esta mostrada na foto 1 a seguir. Muitas dessas chácaras depois de arruadas e loteadas deram origem aos bairros paulistanos. 


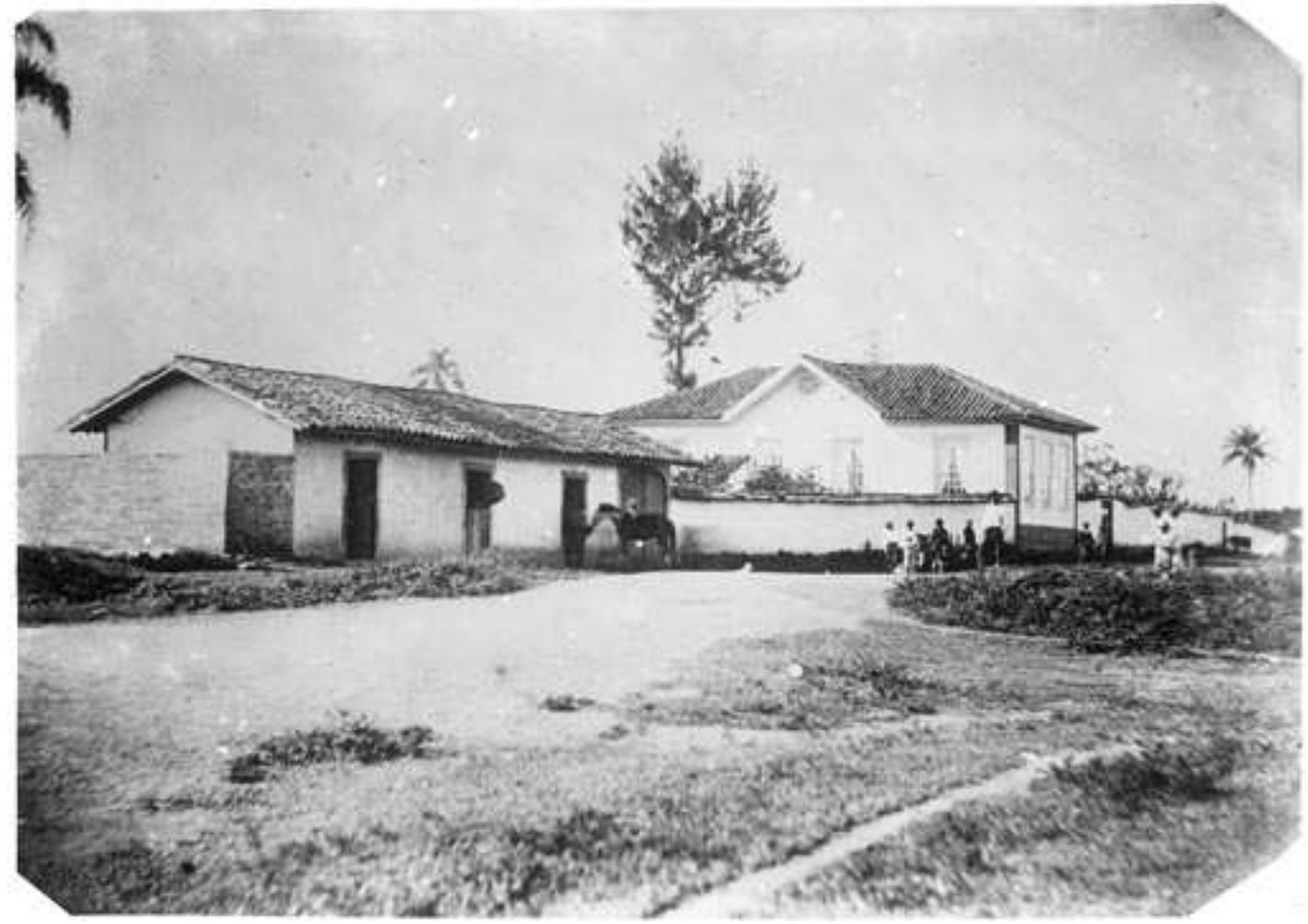

Foto 1 Chácara Bresser 1860 também conhecida como Chácara do Brás Fonte: Acervo Fotográfico da Casa da Imagem Prefeitura de São Paulo Fotógrafo: AZEVEDO, Militão Augusto de 


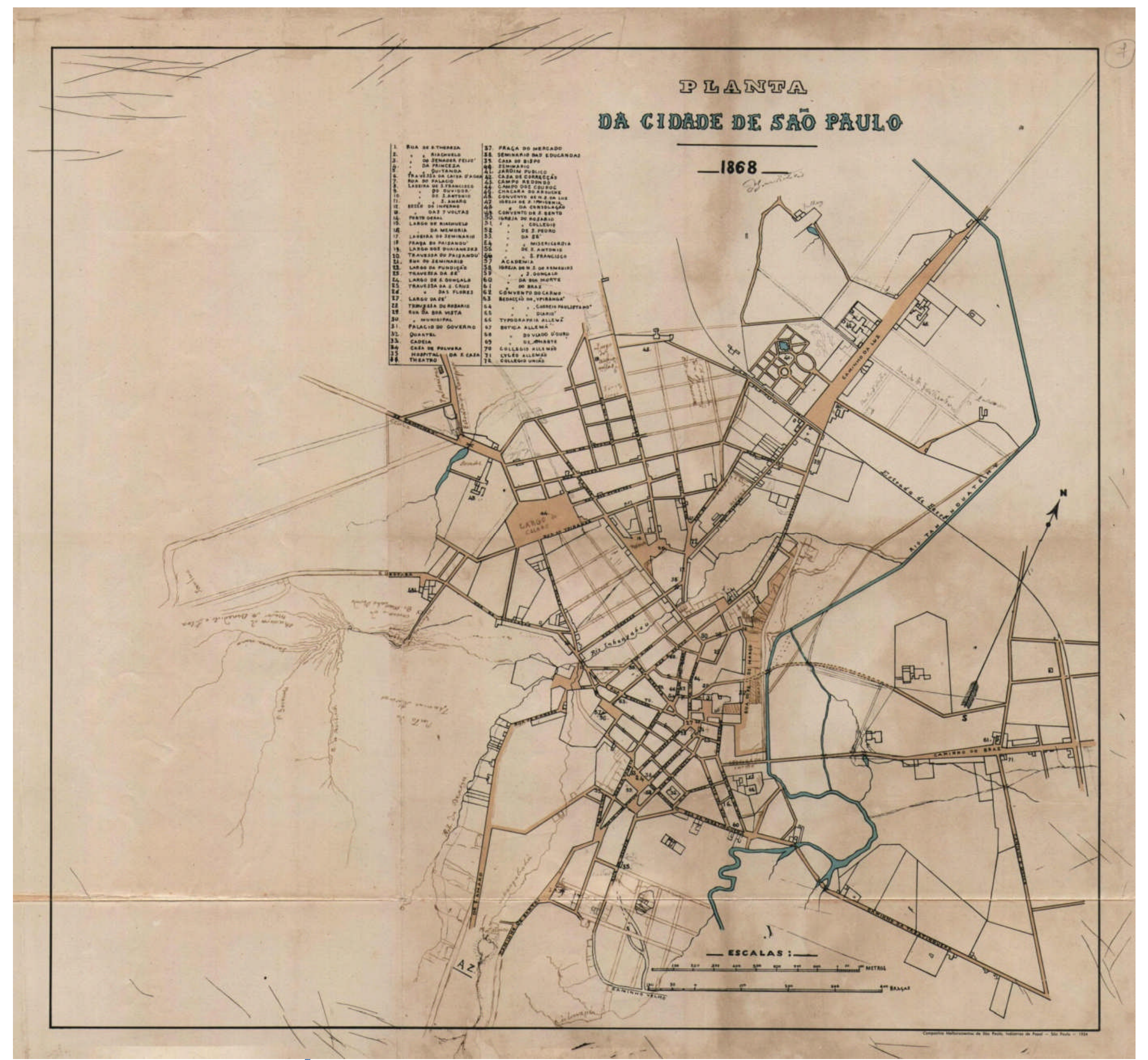

Mapa 4 PLANTA DA CIDADE DE SÃO PAULO - 1868 - Carlos Frederico Rath (atribuída) Fonte: (São Paulo (SP). Comissão do IV Centenário da Cidade, 1954) 
Esse mapa foi selecionado para análise por ser, dentre os mapas encontrados, 0 primeiro a mostrar o traçado da linha férrea Santos-Jundiaí, a qual havia sido inaugurada no ano anterior.

\section{a) Análise cartográfico-iconográfica}

Autoria. Segundo (CAMPOS E. , 2008), essa "planta é tradicionalmente atribuída a Carlos Frederico Rath" (1802-1876), engenheiro alemão que veio para o Brasil em 1845, naturalizando-se brasileiro. Trabalhava em projetos para a Câmara e Governo da Província de São Paulo, responsável por pareceres, execução e planejamento de obras públicas de abastecimento de água, parcelamento de glebas, melhorias de vias de circulação e canalização de rios. Esse mapa é uma reprodução que faz parte do álbum de plantas históricas São Paulo Antigo: Plantas da Cidade, publicado em 1954 pela Comissão do IV Centenário.

Escala, Orientação e Pontos de Referência. A escala é indicada graficamente em metros e braças na parte inferior do mapa. O mapa está orientado para o norte, conforme seta de orientação desenhada em sua lateral direita.

Cores, convenções cartográficas símbolos e outros detalhes. A reprodução aqui apresentada tem coloração amarelada. O principal rio representado é o Tamanduateí, pelas duas margens, em cor azul; os demais corpos de água são representados em linha simples, também em azul, exceto o Anhangabaú, representado em preto, em um certo trecho, e com sua continuidade feita a lápis em cor marrom. As ruas e os quarteirões são representados por linhas duplas em preto, preenchidas pela cor marrom. Existe uma numeração, de 1 a 72 , no canto esquerdo do mapa, logo abaixo do título, e que corresponde a edifícios, ruas, largos, praças, conventos, quartel, palácio do governo, igrejas, chácaras, colégios, seminário, jardim público e botica, todos representados no mapa. Ainda consta no mapa o traçado de ruas e quarteirões em cor marrom claro nas proximidades da Rua Formosa, Rua Tabatinguera e Jardim da Luz; nessa mesma cor ainda são traçados rios como Lavapés e Bexiga, além de algumas anotações feitas para completar e nomear elementos do mapa como as estradas de Sorocaba e de Campinas. 


\section{b) Análise iconológica}

Essa planta apresenta o traçado da ferrovia Santos - Jundiaí recém inaugurada em 1867. Segundo (REIS, 2004): "É o primeiro trabalho cartográfico conhecido que já inclui a linha férrea da São Paulo Railway". Também desperta interesse na medida em que mostra traçados de ruas ainda inexistentes na época de sua confecção, sugerindo a idéia de planejamento urbano.

O mapa foi elaborado provavelmente com finalidade pessoal do seu autor, para o estudo de suas obras hidrológicas e de urbanismo. O autor, responsável por obras de saneamento da cidade como, por exemplo, a construção do cemitério da Consolação, também elaborou um mapa em 1855 para estudos hidrológicos da cidade, onde, em nota abaixo do título, declara o uso pessoal da planta. Carlos Rath trabalhava em projetos para a Câmara e para o Governo da Província de São Paulo, responsável por pareceres, execução e planejamento de obras públicas de abastecimento de água, de parcelamento de glebas, de melhorias de vias de circulação e de canalização de rios. (SALGADO, 2009)

Destaca-se ainda o uso prático do mapa, sem preocupações artísticas: mostra as ruas já existentes em cores mais fortes, e, em tons mais claros, as ruas e as quadras planejadas.

O contexto histórico de elaboração desse mapa revela realmente o caráter de planejamento da obra. Alguns fatos marcam o período da confecção do mapa de 1868 como o aumento populacional da cidade que, em 1886, possuía em torno de 47 mil habitantes e, em 1897, passa a 130 mil habitantes (ROLNIK, 2007). A cidade tinha carência de mão de obra como técnicos e engenheiros para planejamento e execução de obras; a maioria dos engenheiros era estrangeira, como o próprio Rath, e se ocupavam de várias obras.

O abastecimento de água em São Paulo no século XIX era deficitário, o serviço de distribuição era restrito e a quantidade de água disponível nos tanques e chafarizes da cidade era pouca, além de haver problemas de contaminação.

Em 1867, é inaugurada a primeira ferrovia que passava pela cidade ligando a cidade de Santos à Vila de Jundiaí.

Iniciava-se um processo de loteamento de chácaras para venda de lotes.

Aparecem no mapa alguns elementos que podem ser considerados condicionantes do crescimento urbano, como as várzeas do Tamanduateí e do Brás. Através de 
obras de retificação e aterro, as várzeas tornam-se ocupáveis e transitáveis. É possível notar também o aparecimento de novas ruas agregadas aos caminhos principais da cidade, de modo a formar um "esqueleto" das vias de expansão do local.

A ferrovia também aparece como elemento ao mesmo tempo estruturante e limitante da expansão urbana, pois novas ruas surgem paralelas a ela. Como elemento limitante, a ferrovia necessita ser cruzada; o que pode ser feito em nível nos inícios (cancelas), ou por de viadutos, os quais seriam construídos pouco a pouco. Ao mesmo tempo, a linha férrea vai sendo isolada por muros e terrenos exclusivos para evitar acidentes com animais, pessoas e veículos.

Com isso, a cidade fica compartimentada pela ferrovia: algumas poucas passagens canalizam o trânsito; as ruas são traçadas paralelamente e perpendicularmente às ferrovias. Futuramente, há um deslocamento das atividades comerciais e de serviços como hospedarias para imediações da linha férrea. Como explica (BRUNO, 1954) com relação ao comércio de alimentos: "Mas o comércio de "gêneros da terra" começou a se deslocar decisivamente do Piques $^{38}$ para a zona das estações ferroviárias."

Concluindo a análise, esse mapa apresenta uma visão de cidade atual e futura proposta pelo autor, e nem todos os traçados propostos foram concretizados. Mostra uma cidade que está se expandindo através dos loteamentos e de obras públicas como arruamentos, pontes e serviços de água, luz e transporte, resultado não só do processo econômico pelo qual passava a cidade, mas também da adoção de novas posturas e leis sobre as terras.

O mapa expressa a visão do autor em relação à cidade e como esta deveria organizar-se para crescer. Numa visão de conjunto, esse mapa parece indicar o caos de uma cidade que quer se organizar.

A foto 2 logo a seguir mostra o Largo do Piques em 1862, com os carros de carga estacionados.

\footnotetext{
${ }^{38}$ Região central de onde partiam os caminhos de tropas.
} 


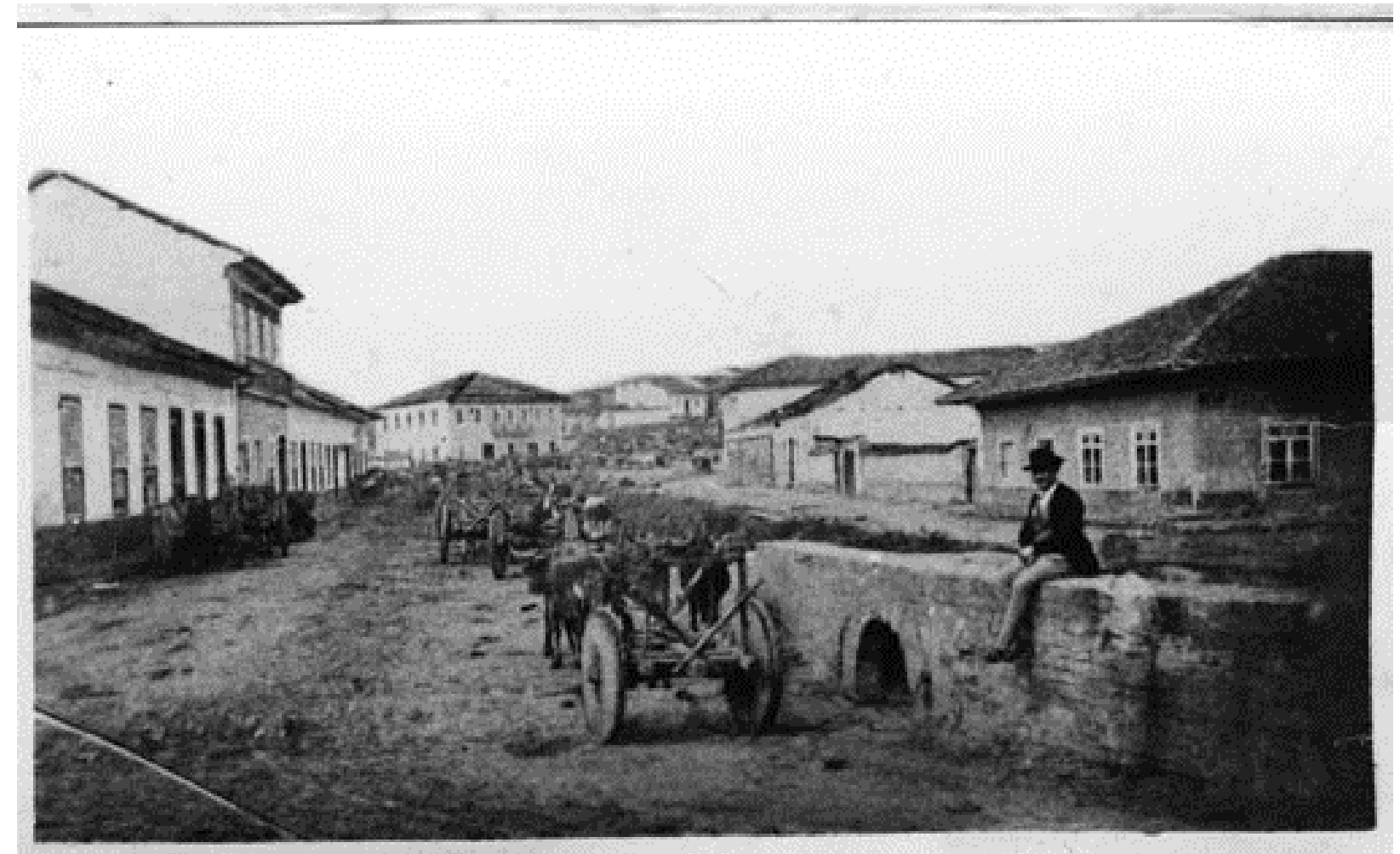

Foto 2_Largo do Piques_1862_Atual Praça das Bandeiras

Fonte: Acervo Fotográfico da Casa da Imagem - Prefeitura de São Paulo Fotógrafo: desconhecido 


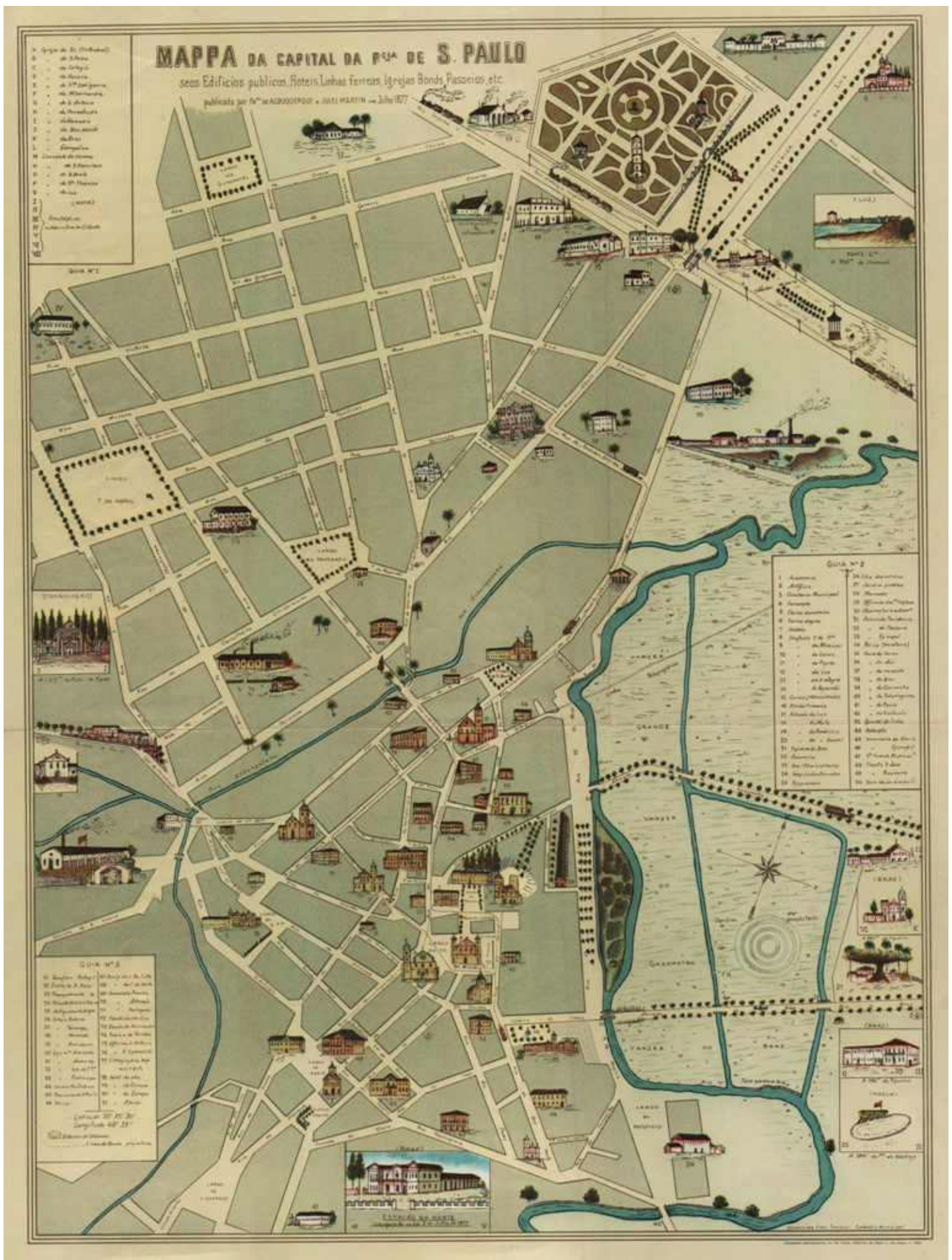

Mapa 5_MAPPA DA CAPITAL DA P. ${ }^{\text {Cia }}$ DE S. PAULO - Fr. $^{\text {do }}$ de ALBUQUERQUE e JULES MARTIN em 1877

Fonte: (São Paulo (SP). Comissão do IV Centenário da Cidade, 1954) 


\section{a) Análise cartográfico-iconográfica}

Essa planta inclui, pela primeira vez, a informação das principais linhas de bondes, com tração animal, da Companhia Carris, além de mostrar as edificações mais importantes da cidade da época, na segunda metade do século XIX. A reprodução apresentada pertence ao álbum Plantas Históricas de São Paulo Antigo: Plantas da Cidade, publicado em 1954 pela Comissão do IV Centenário.

Autoria: Fernando de Albuquerque ${ }^{39}$ e Jules Martin eram artistas plásticos; este último, imigrante francês (litógrafo), foi responsável pelo projeto de construção do Viaduto do Chá, no final do século XIX (REIS, 2004). No rodapé do mapa há informação do desenhista copista: "Fran. Sansoni: Cadastro municipal".

Escala, Orientação e Pontos de Referência. As coordenadas geográficas "Latitude $23^{\circ} 23^{\prime \prime} 30^{\prime}$ e Longitude $48^{\circ} 59^{\prime}$ aparecem na legenda, que se presume serem do centro da cidade (Pátio do Colégio) ${ }^{40}$. Na parte esquerda do mapa, sobre a várzea do Carmo, há o desenho de uma rosa dos ventos indicando o Norte, sendo esta a orientação do mapa.

Cores, convenções cartográficas símbolos e outros detalhes. O mapa apresenta ruas, quarteirões, parques e rios de forma bem definida; os principais edifícios da cidade são desenhados em perspectiva, mantendo algumas das características próprias como as torres, as janelas e a arquitetura. $\mathrm{O}$ autor desenhou também fábricas e linhas de bonde e de trem. São destacados em pequenos quadros nas laterais do mapa a Estação do Norte, o Hipódromo, o Palácio Episcopal, a Igreja do Braz e a Ponte Grande. O autor também traçou as linhas de bondes a tração animal. O mapa mostra três quadros laterais com numeração e convenções utilizadas; compõem esses quadros os nomes de edifícios, pontes, ruas, hotéis e serviços como: hospitais, colégios, lojas, consulados e escritórios. Os rios representados no mapa são o Anhangabaú e o Tamanduateí. Sua ênfase está realmente em mostrar os acessos de bondes e de ferrovia, e os edifícios públicos e serviços oferecidos pela cidade na época.

\footnotetext{
${ }^{39}$ Conforme proposta feita por (CINTRA, Plantas Históricas, 2004)

${ }^{40}$ (CINTRA, Plantas Históricas, 2004) identificou erro nessas coordenadas.
} 


\section{b) Análise iconológica}

Ao comparar o mapa de 1877 com o mapa selecionado anteriormente, de 1868, a diferença entre a cidade representada é de "caos" e "ordem", respectivamente. Caos quando o mapa aparece como rascunho, com linhas traçadas de forma desordenada, e de ordem quando a cidade aparece bela, com desenhos artísticos e perfeitamente organizada em suas ruas, seus edifícios e seu transporte. Pode-se imaginar que a cidade não era perfeitamente ordenada, mas também tinha uma certa ordem, ou seja, havia transporte por bondes puxados por animais partindo do centro da cidade em direção às estações do trem de Santos-Jundiaí que cruzava a cidade de Leste a Oeste. Segundo (MORSE, 1970, p. 248): "Em 1877 havia sete linhas com 25 quilômetros de trilhos, 319 animais e 43 carros que transportavam 1 500000 passageiros por ano. Além dessas linhas, havia uma pequena estrada de ferro que ligava Santo Amaro, na periferia, à cidade." Como apresenta o autor citado, o número de passageiros transportados era grande se compararmos com a população recenseada em 1872, que era de $31385^{41}$ habitantes.

Ao que parece, esse mapa tem um caráter turístico ao representar a cidade de forma tão organizada e agradável ao leitor.

O autor utilizou uma técnica de perspectiva primitiva para compor as principais edificações que estão representadas no mapa; talvez numa tentativa de atingir o maior número de usuários possível, de "se fazer entender" através dos desenhos, para facilitar a extração de informações básicas como por onde passam os bondes, ou onde está a ferrovia, sem a necessidade de se recorrer à legenda.

As áreas de lazer da cidade aparecem em destaque, como praças, hipódromo e Jardim Botânico. Até a várzea do rio Tamanduateí aparece "enfeitada": o autor desenhou sobre ela a rosa dos ventos e um jardim projetado.

Diferentemente dos mapas utilizados para estudos, ou dos mapas manuscritos, este foi produzido em larga escala para a época, provavelmente com a litografia ${ }^{42}$, técnica na qual seu autor Jules Martin era especializado.

\footnotetext{
${ }^{41}$ FONTE - Annuario estatistico do Brazil 1908-1912. Rio de Janeiro: Directoria Geral de Estatistica, v. 1-3, 1916-1927

${ }^{42}$ Processo de reprodução que consiste em imprimir sobre papel, por meio de prensa, um escrito ou um desenho executado com tinta graxenta sobre uma superfície calcária ou uma placa metálica, ger. de zinco ou alumínio; impressão química. (Dicionário Houaiss)
} 
Esse mapa pode ser considerado um mapa estático, pois, ao ressaltar apenas o centro da cidade, não apresenta a ideia de sua expansão, mostrando como que um retrato momentâneo da situação. 


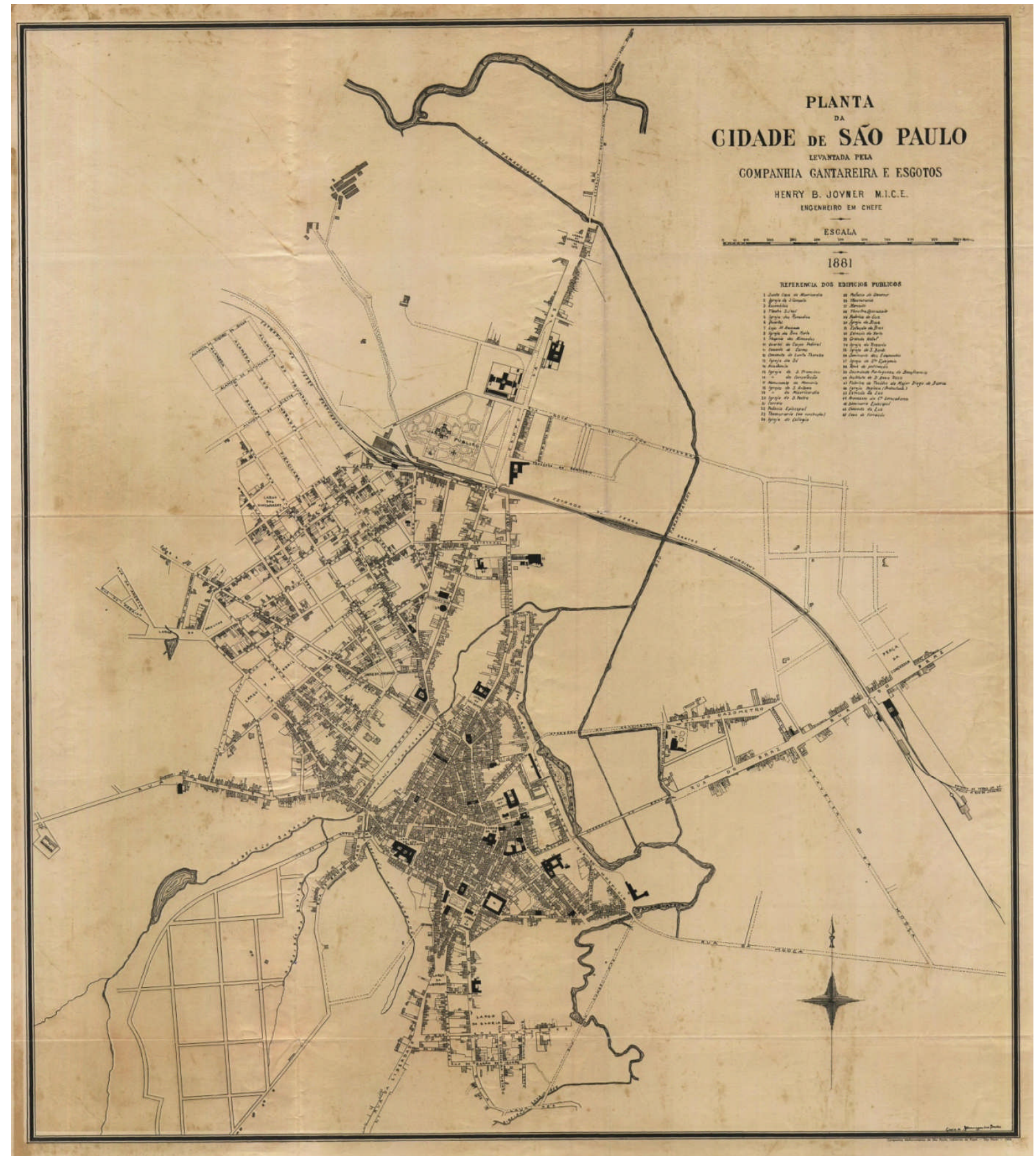

Mapa 6 PLANTA DA CIDADE DE SÃO PAULO LEVANTADA PELA COMPANHIA CANT AREIRA E ESGOTOS por HENRY B. JOYNER M.I.C.E. ENGENHEIRO EM CHEFE 1881 - Cópia de Domingues dos Santos

Fonte: (São Paulo (SP). Comissão do IV Centenário da Cidade, 1954) 


\section{a) Análise cartográfico-iconográfica}

Essa planta mostra a cidade no final do século XIX, já com o traçado das ferrovias S.P. Railway (Santos-Jundiaí), Sorocabana e São Paulo-Rio de Janeiro (futura Central do Brasil) estas últimas instaladas em 1875. É possível observar a expansão das edificações para oeste, assim como o traçado de novos loteamentos ao sul e ao norte da linha férrea.

Autoria. A planta foi elaborada pela Companhia Cantareira de Águas e Esgotos, para o serviço de água e esgotos, tendo como finalidade o planejamento urbano. É possível ver que, diferentemente da planta de Jules Martin, esta abarca a área urbanizada total da cidade. A Companhia foi fundada em 1877 com o intuito de implantar e ordenar o sistema de distribuição de água na cidade. Para isso, a empresa construiu o primeiro grande reservatório de água na cidade, o reservatório da Consolação, devidamente representado no mapa. O mapa aqui utilizado é uma reprodução feita na edição do álbum do IV Centenário da cidade.

Escala, Orientação e Pontos de Referência. Há uma escala gráfica representada de 100 em 100 metros no mapa, logo abaixo do título. Segundo (CINTRA, 2004)a escala foi determinada como sendo 1:5.000. O mapa está orientado para o Norte, e possui desenhada uma rosa dos ventos no canto direto. Estão representados como referência os rios Tietê, Tamanduateí, Anhangabaú e outros menores. Outro elemento de referência são as linhas férreas que, nesse período, já eram três; entre a seleção de mapas feita, esse é o primeiro a representar as três linhas conjuntamente e sua inserção na cidade de São Paulo.

Cores, Convenções Cartográficas e Outros Detalhes. A cópia aqui estudada encontra-se em papel amarelado, e todos os elementos são desenhados em tons que variam do cinza, para edificações pequenas ( preenchidas por essa cor) e ao preto, utilizado para o contorno dos edifícios públicos e para o traçado de linhas internas na representação da hidrografia. Os edifícios públicos receberam uma numeração, e, na parte superior direita do mapa, há uma listagem com a numeração e o significado correspondente. Algumas ruas aparecem em tracejado, como a travessa da Moóca. 


\section{b) Análise iconológica}

A planta analisada foi elaborada para o uso funcional de planejamento da empresa de abastecimento de água da cidade de São Paulo.

É uma planta de natureza cadastral, mostrando edifícios públicos, casas e lotes.

Observa-se que os lotes "vazios" são representados no mapa como planejamento, para prever futuras demandas de abastecimento.

No mapa, é possível notar o adensamento da cidade e seu eixo de expansão nas direções noroeste e sudoeste.

O reservatório de água é representado, mas não outras caixas de água ou o traçado das adutoras que farão a distribuição de água na cidade.

Ao que parece, a planta tem um sentido, uma finalidade de planejamento no que tange ao crescimento da cidade, mas não especificamente do planejamento de obras. Ainda, diferentemente da planta de Jules Martin, esta não é voltada ao público em geral, mas ao planejador, à empresa e ao governo.

As linhas férreas aparecem como fator limitante da mancha urbana, ao longo dela e nas suas proximidades. O Tamanduateí, que começa a ser canalizado, também é um elemento estruturante da cidade. 


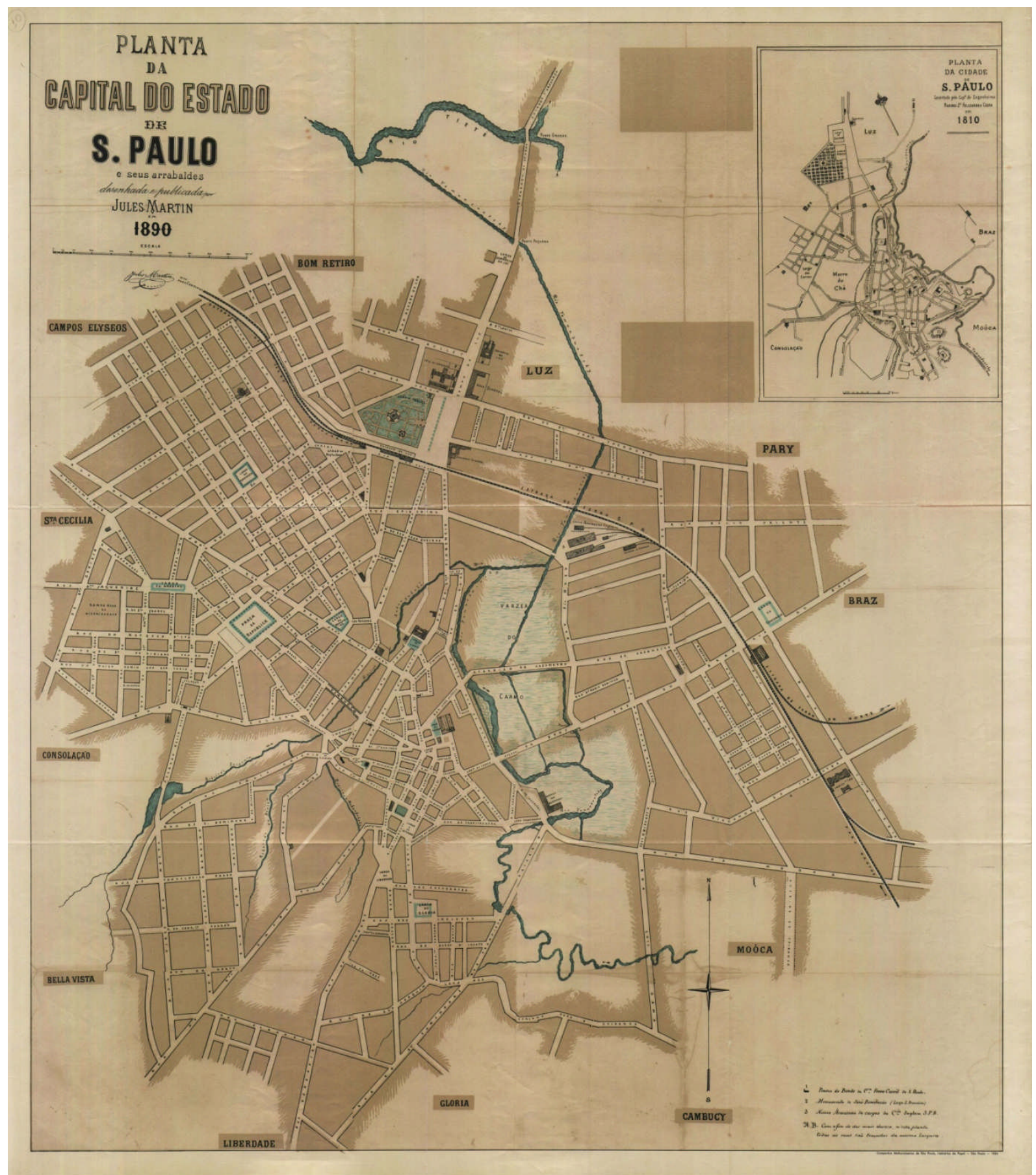

Mapa 7_Planta da Capital do Estado de S. Paulo e seus arrabaldes, desenhada e publicada por Jules Martin em 1890

Fonte: (São Paulo (SP). Comissão do IV Centenário da Cidade, 1954) 


\section{a) Análise cartográfico-iconográfica}

A planta publicada por Jules Martin, após a proclamação da República, mostra a cidade e seus arredores; como descrito no título, traz também no canto superior direito um quadro com a Planta de 1810 feita por Rufino na versão de 1841 . (CINTRA, 2004)

Autoria. Jules Martin, como já exposto, era um artista plástico francês, que, em 1871, fundou a primeira litografia da cidade. Além de autor e desenhista da planta, Jules Martin também foi responsável por sua publicação. (CINTRA, 2004)

Escala, Orientação e Pontos de Referência. No mapa aparece, logo abaixo do título, uma escala gráfica em metros; (CINTRA, Plantas Históricas, 2004) confirma a escala numérica da planta em 1:6000. Quanto à orientação, a planta está orientada para o Norte, conforme a rosa dos ventos desenhada na parte inferior direita do mapa. Os pontos de referência nesse mapa aparecem bem visíveis, tanto os rios, os nomes de bairros, como as ruas e as edificações.

Cores, Convenções Cartográficas e Outros Detalhes. A cópia do mapa observada é composta de cores bege para a mancha urbana, branca para ruas, azul nos rios, verde para contorno de largos e praças, preto para edifícios, e, para várzeas, branco com traços esparsos de verde. Esse mapa mostra os aterrados do Braz, de Santana e do Gazômetro, na várzea do Carmo. A nota na parte inferior do mapa diz que estão representados os pontos de "bonds" da Cia Ferro Carril de São Paulo, os novos armazéns de cargas da São Paulo Railway, o Monumento de José Bonifácio (Largo S. Francisco); e noutra nota: "Com o fim de dar mais clareza, n'esta planta todas as ruas são traçadas da mesma largura."

\section{b) Análise iconológica}

Assim como o mapa de 1877 (mapa 5), também feito por Jules Martin, este é impresso para o público em geral; guarda diferenças com o mapa anterior produzido pelo mesmo autor por não se apresentar tão artístico e também por expandir a representação para além do centro da cidade.

Mostra a mancha urbana em 1890, com os limites ampliados em relação às plantas anteriores, ultrapassando a ferrovia através de passagens de nível ou cruzamentos. Os nomes dos bairros em formação como Pary [sic], Bom Retiro, Campos Elyseos 
[sic], Stª Cecília, Bella Vista [sic], Gloria, Cambuci e Moóca aparecem no mapa mostrando um crescimento da cidade em todas as direções.

Após a proclamação da República, no final do ano de 1889, as antigas chácaras foram loteadas e arruadas, dando origem aos bairros de Santa Ifigênia, Bom Retiro, Brás, Consolação, Liberdade, Cambuci, Higienópolis, Avenida paulista, Moóca, Pari, água Branca, Barra Funda e Ipiranga. (BRUNO, 1984)

Devido à importância do processo migratório que ocorria na época, a hospedaria dos imigrantes é representada no mapa, ao lado da linha férrea Santos-Jundiaí, no bairro do Brás, com o nome IMMIGRAÇÃO (na cópia estudada, as letras R, A e Ç estão apagadas).

O autor representa as três linhas férreas, Sorocabana, Central do Brasil e S.P.R., juntamente com os novos armazéns da linha inglesa (São Paulo Railway-S.P.R.).

Em vez de representar as quadras e as edificações da cidade, o autor representou a área ocupada por uma mancha de cor bege, dando a entender que esta seria a área ocupada da cidade, enquanto que a área ainda não ocupada permanecia em branco, sem a mancha. 


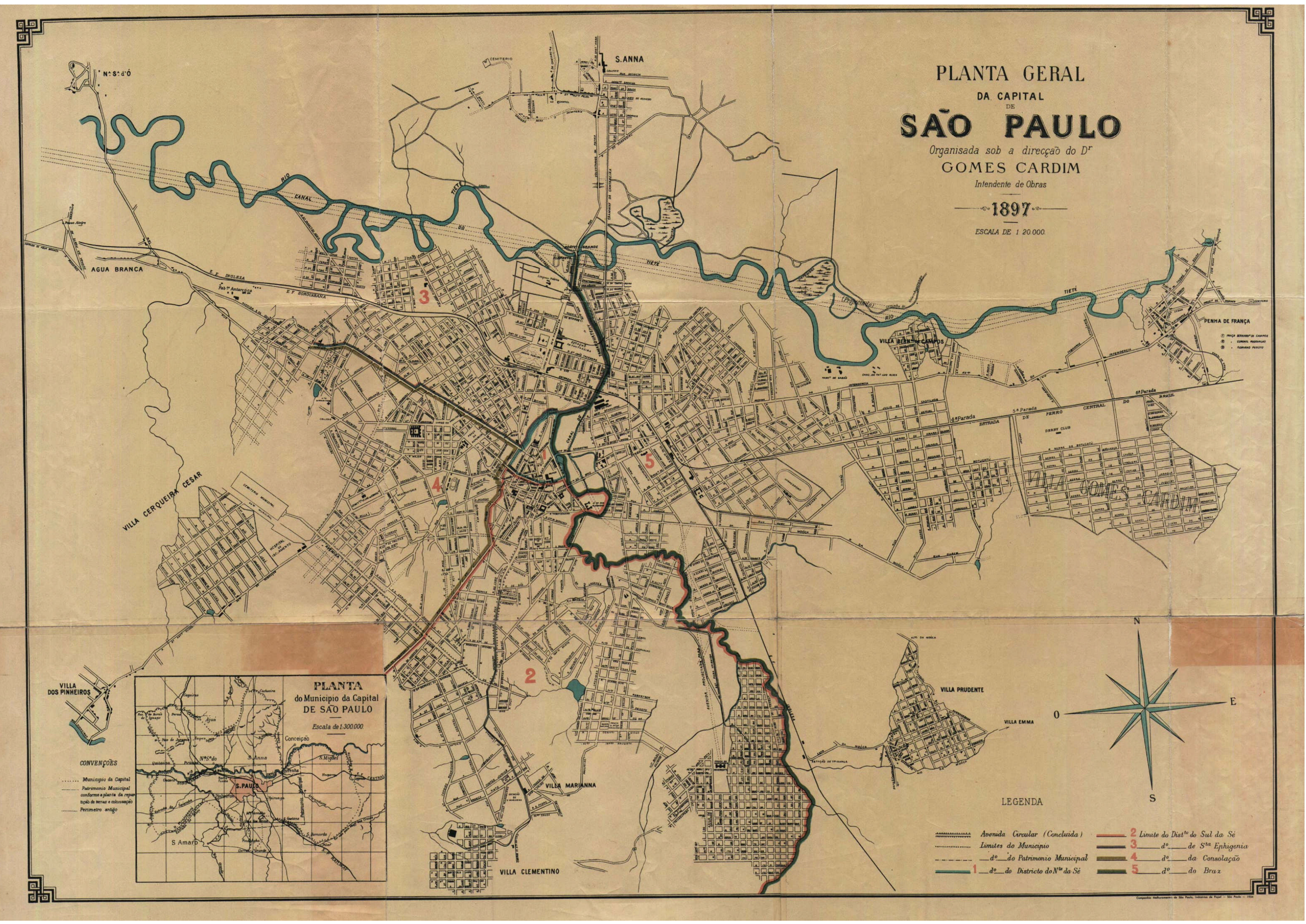

Mapa 8_Planta Geral da Capital de São Paulo Organisada sob a direção do Dr. Gomes Cardim em 1897 Fonte: (São Paulo (SP). Comissão do IV Centenário da Cidade, 1954) 
O mapa 8 apresenta a área urbana da cidade com seus limites expandidos no final do século XIX, mostrando traçados de loteamentos arruados, as linhas férreas Inglesa, Sorocabana e Central do Brasil, e suas principais estações. Como já mostra uma cidade expandida além do núcleo central, inclui na representação da hidrografia o Rio Tietê e um pequeno trecho do Rio Pinheiros. Essa planta foi estudada em detalhe por (SIMONI, 2009), que a considerou não uma representação da cidade existente nem um plano, mas uma "carta de compromisso". Nas palavras da autora citada:

[...]a elaboração da Planta Geral da Capital de São paulo de 1897, passou de uma perspectiva racional ou funcionalista de elaboração de um plano de extensão da cidade a ser desenvolvida junto à instituição pública nos moldes repúblicanos, para uma peça gráfica, em grande parte fruto de uma colagem de interesses, submetidos à decisão dos proprietários de terras, que individualmente riscaram os traçados viários, nas suas plantas parciais representativas de suas propriedades. (SIMONI, 2009, p. 16)

\section{a) Análise cartográfico-iconográfica}

Autoria. Pedro Augusto Gomes Cardim, que foi intendente de Obras Públicas da Câmara Municipal de São Paulo, em 1897 (CINTRA, 2004).

Escala, Orientação e Pontos de Referência. A planta possui escala numérica de 1:20.000, conforme descrição abaixo do título; apresenta uma generalização cartográfica diferente das outras plantas, pois sua escala é menor. Por representar uma visão de conjunto, é possível ver os novos bairros que estão em formação na cidade, assim como núcleos mais afastados, como a Penha ou Santana, que não foram representados nos mapas anteriores. No canto esquerdo do mapa, há um quadro com a Planta do Município da Capital, em uma escala de 1:300.000, o qual mostra a mancha urbana da cidade de São Paulo no centro, em cor avermelhada, a rede hidrográfica principal, as estradas de ferro e localidades como: Osasco e Pirituba a Oeste, S. Bernardo e S. Amaro ao Sul, S. Miguel e Penha a Leste e Santana, Arujá e Cachoeira ao Norte. Nesse quadro, a legenda mostra o tracejado 
utilizado para representar os limites do município da Capital, o Patrimônio Municipal, conforme a planta da repartição de terras e "colonisação"[sic], e o perímetro antigo.

O mapa está orientado para o Norte, e possui uma rosa dos ventos no canto direito para essa orientação.

Cores, Convenções Cartográficas e Outros Detalhes. A cópia utilizada no estudo possui coloração amarelada, mas as cores estão bem definidas. Os rios principais estão representados em azul; há um tracejado ao longo do rio Tietê indicando um canal projetado. Os principais edifícios públicos são representados em preto. As linhas férreas são representadas por um traço contínuo preto, e suas principais estações também são mostradas no mapa. Na sua legenda, estão os limites dos cinco distritos que compunham a cidade, os limites do município e a avenida circular concluída.

\section{b) Análise iconológica}

Até o mapa de 1890, analisado anteriormente, a estruturação da cidade restringiu-se ao chamado "centro velho" e seus arredores, numa escala de 1:5.000 ou 1:10.000. A partir do mapa de Gomes Cardim, os limites da cidade representada aparecem realmente expandidos, numa área muito maior, com o mapa na escala 1:20.000, e no encarte no canto inferior esquerdo aparece uma planta de situação mostrando a cidade em um contexto maior, trazendo bairros afastados não anexados ao centro, como Vila Prudente, Vila Clementino, Cerqueira César, Santana, Água Branca, Freguesia do Ó, Penha de França, Villa [sic] dos Pinheiros. Vê-se claramente a cidade em expansão, numa dinâmica de ocupação dos espaços intermediários.

No eixo leste, percebe-se o desenvolvimento da cidade ao longo da ferrovia; os arruamentos são paralelos e perpendiculares a ela, e as estações ganham nomes de paradas do trem, como da $1^{\text {a }}$ à $4^{\text {a }}$ Parada, na zona leste, e alguns desses nomes permanecem até os dias de hoje.

Para oeste, o crescimento da cidade parece condicionado pelas avenidas Paulista e Consolação.

Ao norte, o Rio Tietê ainda limita o crescimento da cidade, com exceção dos bairros de Santana e Nossa Senhora do Ó, que apesar de não muito significativos, encontram-se representados no mapa; no entanto, constituem pontos de formação 
que vão se expandir simultaneamente com a mancha central, num movimento de atração mútua.

Tem-se a impressão de que o autor do mapa quis mostrar as possibilidades de crescimento da cidade no final do século XIX, acrescentando ao mapa não só os arruamentos existentes, mas alguns dos previstos. Mesmo assim, ainda restaram extensos vazios no mapa.

Os transportes por trilho a vapor, como o Tramway da Cantareira, que servia à Cia. de Abastecimento de Água e aos moradores de Santana, estão representados no mapa, assim como o Tramway que partia da Estação S. Joaquim, no bairro da Liberdade, e ia até o Matadouro da Vila Mariana / Vila Clementino. A ferrovia parece "despertar" novos núcleos de moradia e de trabalho. Como destaca (MORSE, 1970, p. 250):

\begin{abstract}
A São Paulo Railway, em parte pela sua vasta quantidade de desvios veio determinar a forma de ocupação de uma faixa industrial que se estendeu por um amplo arco a este ao norte do centro, e do qual muitos terrenos já eram indesejáveis por serem baixos e úmidos. Neste arco, principalmente no Brás e na Moóca, foi morar a maioria dos trabalhadores.
\end{abstract}

As avenidas projetadas como, por exemplo, a "Avenida Projetada para o Monumento do Ypiranga", que parte da proximidade da rua da Moóca em direção ao Ypiranga [sic], assim como os projetos de canalização, irão provocar mudanças da cidade através de novos acessos e também de desapropriações.

O mapa como um todo mostra também os avanços técnicos da cartografia no que diz respeito às convenções e às generalizações.

Como o mapa possui uma escala menor em relação aos outros (1:20000), é possível visualizar uma porção mais extensa da cidade, onde se veem bairros como Santana, Nossa Sra. do Ó, Água Branca, Villa [sic] Cerqueira César, Villa [sic] dos Pinheiros, Ypiranga [sic], Villa Prudente [sic], Penha de França e Vila Gomes Cardim.

Não só a ferrovia e os bondes como também a topografia vão influenciar no processo de ocupação da cidade, deixando as várzeas não drenadas e os divisores de água como "reservas" de loteamentos futuros. 


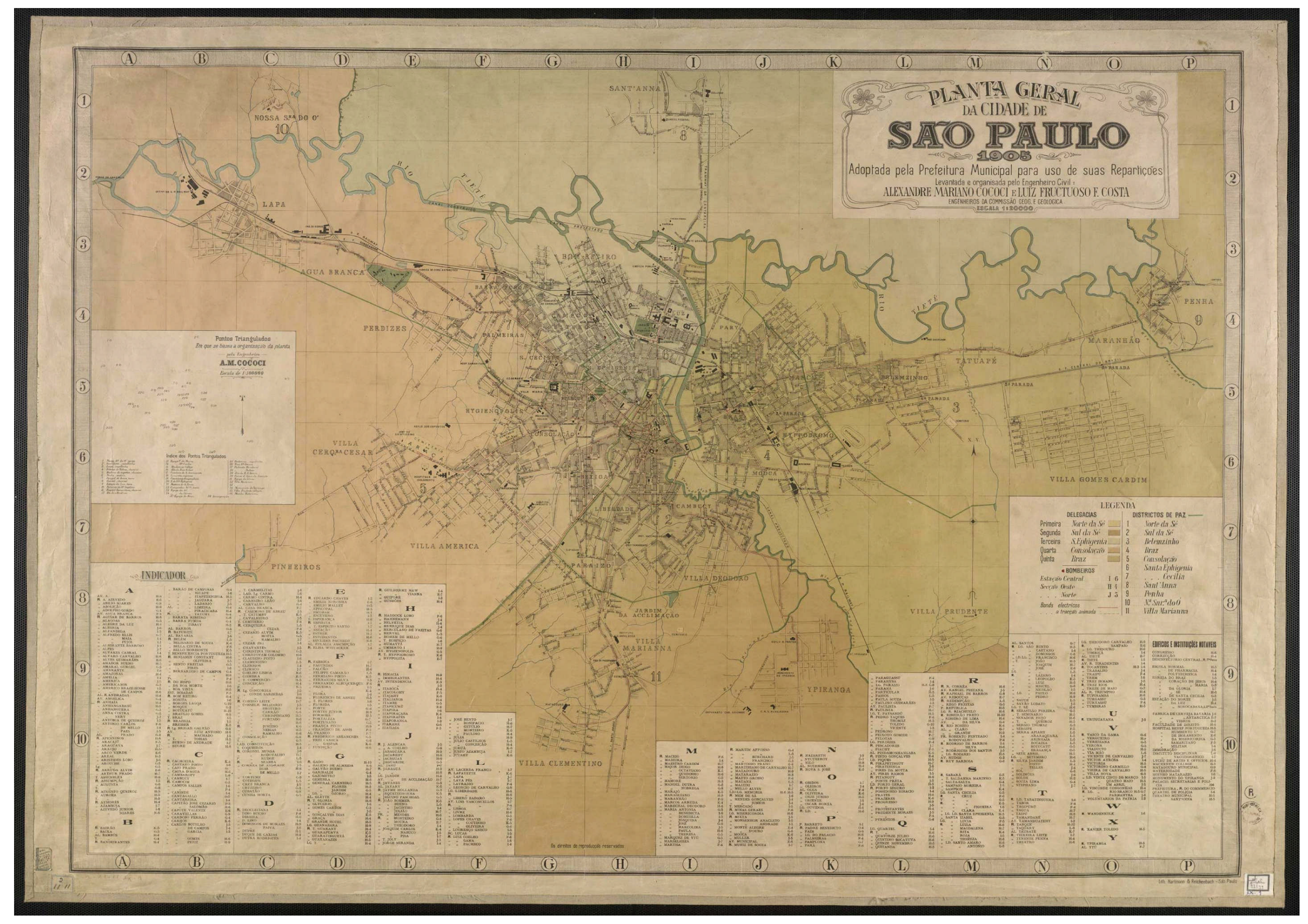

Mapa 9_Planta Geral da Cidade de São Paulo 1905 Fonte: Biblioteca Nacional -RJ 
Elaborada no início do século XX, mostra a área central da cidade e também seus bairros mais afastados, bem como o traçado das linhas de bondes existentes na época, informação até então vista somente no mapa de Jules Martin e Fernando de Albuquerque de 1877, em escala limitada ao centro.

\section{a) Análise cartográfico-iconográfica}

Autoria. Essa parece ser, de acordo com os mapas levantados na pesquisa, a primeira planta oficial da cidade de São Paulo, elaborada no início do século XX pelos engenheiros Alexandre Mariano Cococi e Luiz Fructoso F. Costa, da Comissão Geográfica Geológica, órgão estadual, realizando serviço para o município. Mostra a expansão de cidade no início do século XX. A partir dessa planta, as indicações técnicas tornam-se mais padronizadas e de melhor qualidade cartográfica.

Escala, Orientação e Pontos de Referência. A planta apresenta escala numérica de 1:20.000, mesma escala que a planta anterior de Gomes Cardim, de 1897. Como referência, possui um quadro, na margem esquerda, que mostra uma seta apontando para o norte e os 38 pontos triangulados pela cidade nos quais se baseia a planta. Essa triangulação é o sintoma da existência de um sistema cartográfico implícito de coordenadas. Sua orientação é para o Norte, pois há uma seta com essa indicação desenhada próxima à legenda, na lateral direita da planta. Há também uma grade de referência, sendo numérica nas margens verticais e alfabética nas margens horizontais, para a localização das ruas, que vêm listadas em ordem alfabética nos cantos inferiores da planta. Com o índice de ruas, há também um índice chamado "Edifícios e Construções Notáveis", listando igrejas, hospitais, fábricas, escolas e outros edifícios de uso comum que se destacavam na cidade.

Cores, Convenções Cartográficas e Outros Detalhes. Sua legenda traz as seguintes informações: as cinco regiões de delegacia da cidade e suas respectivas áreas de atuação, representadas por cores distintas. Observando a cópia estudada, não é possível dizer com precisão quais são as cores utilizadas, mas os tons são: bege, amarelo, rosado, cinza e marrom. Observando o conjunto do mapa, é possível perceber as diferentes cores de fundo. As três estações de bombeiros existentes na época são identificadas por um círculo incompleto preenchido pela cor vermelha. Os bondes elétricos são representados por uma linha contínua vermelha, e os de tração 
animal, por uma linha tracejada também vermelha. Os dez distritos de paz da cidade são separados por uma linha contínua de cor verde.

Um sistema de quadrículas representado por letras, nas margens horizontais, e números, nas margens verticais, orienta o leitor a localizar ruas, edifícios, largos e praças na legenda.

\section{b) Análise iconológica}

Dos mapas selecionados, esse é o primeiro produzido no século $X X$; tem um caráter técnico, guarda certa semelhança com o mapa anterior, de 1897, pela escala e forma de representação da cidade, mostra bairros, arruamentos, loteamentos; fato interessante: divide o mapa por cores baseadas nas cinco delegacias da época, o que nos leva a crer que esse mapa pode ter sido confeccionado para uso no planejamento administrativo da cidade. Apresenta não só a divisão por delegacias mas também a divisão por districtos de paz que, na época, eram onze, conforme legenda localizada na margem direita inferior do mapa: Norte da Sé, Sul da Sé, Belenzinho, Braz, Consolação, Santa Ephigenia, Santa Cecília, Sant'Anna, Penha, Nossa Sra. do Ó e Villa Marianna [sic]. No Anuário Estatístico de São Paulo de $1905^{43}$, há uma pequena variação quanto aos distritos: o norte da Sé passa a se chamar Sé, o sul da Sé, Liberdade, e é adicionado o distrito de São Miguel. O traçado dos distritos de paz que estão ao redor da área central, como Belenzinho, por exemplo, engloba os arruamentos 4aㅡ Parada, 5a Parada, Villa Gomes Cardim [sic], Tatuapé e Maranhão, sendo limitados ao norte pelo Rio Tietê, a oeste pelo distrito do Braz, a leste pelo distrito da Penha; ao Sul, não há limite traçado, assim como ocorre ao sul para os distritos do Braz, da Vila Mariana (que engloba Ypiranga [sic], Vila Clementino e Villa Prudente [sic]) e da Consolação (que engloba Bexiga, Higienópolis, Villa Cerqueira César [sic], Villa América [sic] e Pinheiros). Assim, já é possível visualizar uma configuração da cidade dividida por bairros, mas ainda com muitos "vazios" 44.

Nesse mapa, em função da divisão territorial representada pelos distritos estar com os limites "em aberto", todos os "vazios" pertencem a um dos distritos.

Podemos reconhecer esse mapa como sendo o primeiro de uso público da Prefeitura da Cidade, como está grafado no seu título: “Adoptada pela prefeitura

\footnotetext{
${ }^{43}$ (Repartição de Estatística e do Archivo de São Paulo, 1907)

${ }^{44}$ Áreas em branco sem nome nem arruamentos traçados.
} 
Municipal para uso de suas repartições", deixando claro o caráter político, administrativo e funcional do mapa.

Reflete uma estruturação político-administrativa da cidade, ou seja, mais um passo em direção ao planejamento urbano.

Na comparação com o mapa anterior de Gomes Cardim (1897), vemos que esse mapa (1905) mostra os arruamentos de bairros em expansão, como Vila Prudente, Ypiranga [sic], Villa dos Pinheiros [sic], Villa Cerqueira César [sic] e Vila Gomes Cardim, aparecendo em tamanho menor, motivo que leva a crer ter havido uma extrapolação na representação de 1897. 


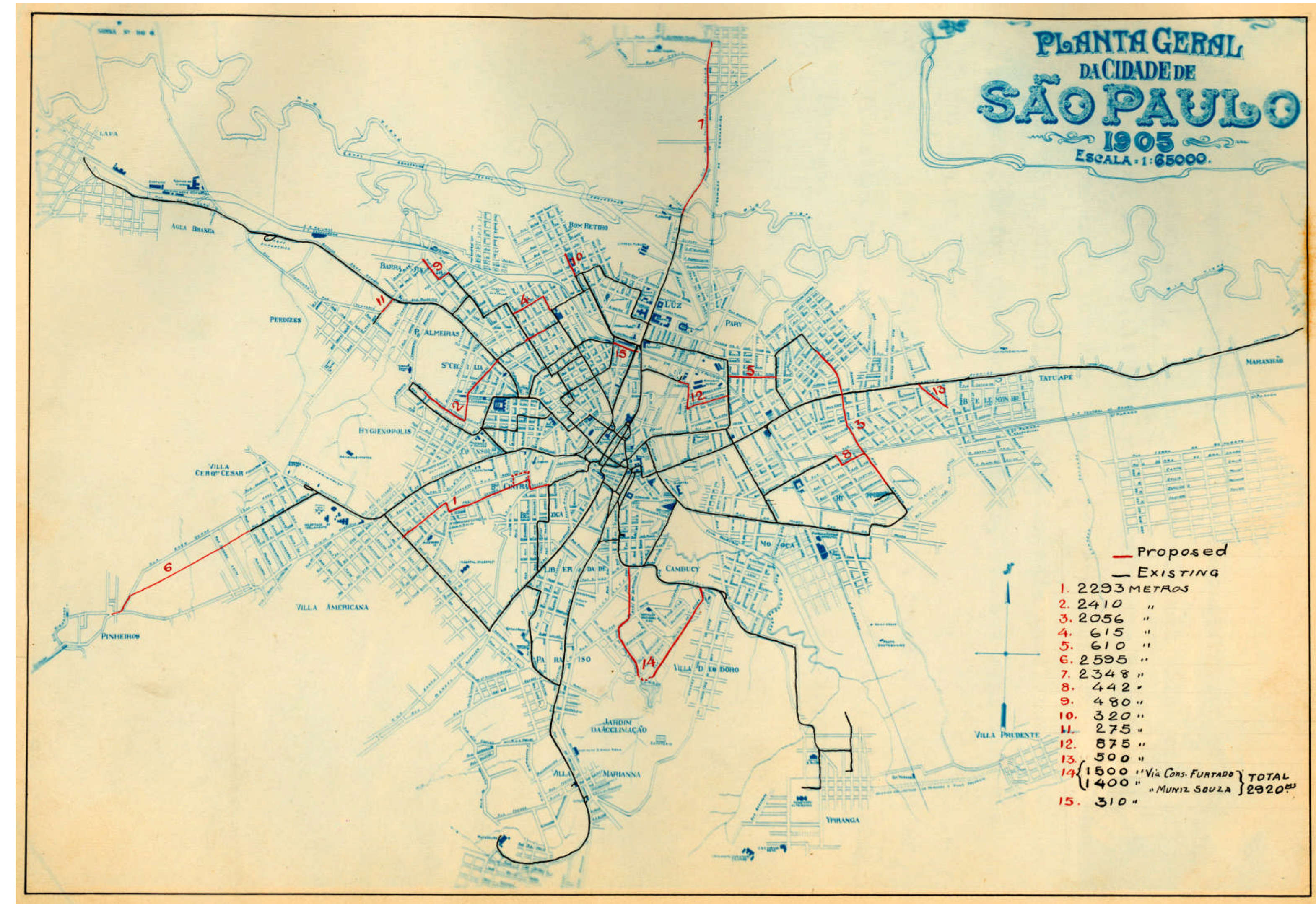

Mapa 10_Planta Geral da Cidlade de São Paulo - Linhas de bondes - 1905 - Light Fonte: Acervo Fundação Energia e Saneamento 


\section{a) Análise cartográfico-iconográfica}

Autoria. Mapa elaborado pela The São Paulo Railway, Light \& Power Company conhecida como Light. Planta do acervo da Fundação Energia e Saneamento, mostra as linhas de bondes existentes na cidade em preto, e as propostas em vermelho. Mostra algumas diferenças, se comparado com o mapa 9 da mesma data, como a escrita do nome dos bairros. Por sua natureza, interessa muito diretamente para a presente pesquisa.

Escala, Orientação e Pontos de Referência. O mapa apresenta uma escala numérica de 1:65000. Está orientado para o norte conforme seta na parte inferior direita do mapa. Como referência, tem-se o rio Tietê, com seus canais projetados, os bairros e a linha férrea, que possibilitam a melhor orientação ao leitor.

Cores, Convenções Cartográficas e Outros Detalhes. O mapa consultado é uma cópia heliográfica em papel branco, já um pouco amarelado, e linhas em azul. A legenda feita à mão, e, em inglês, mostra as linhas de bondes já existentes; as linhas propostas estão numeradas de 1 a 15 na legenda, com o respectivo comprimento em metros. É interessante a comparação desse mapa com o mapa 9 , com relação às linhas de bonde.

\section{b) Análise iconológica}

O mapa elaborado para a função de planejamento das linhas de bondes elétricos que serviam a cidade de São Paulo, em 1905, mostra os bairros servidos de bondes. $\mathrm{Na}$ região do triângulo central da cidade, havia uma concentração de linhas de bondes interligadas, muitas partindo do antigo largo do Rosário.

Ao norte, uma linha servindo do centro em direção ao bairro de Santana, até o rio Tietê (Ponte Grande), como uma proposta de expansão até o centro do bairro de Santana. Ao leste, uma linha paralela à linha férrea, Central do Brasil, que servia até o bairro da Penha. Ao sudeste, uma linha que seguia da Liberdade até a Vila Clementino, finalizando o trajeto no Matadouro Municipal. Também havia a linha Ypiranga [sic], que partia da Liberdade em direção ao monumento do Ypiranga [sic], com proposta de duas ramificações, partindo dessa linha em direção ao Jardim da Aclimação. Para o sudoeste, havia uma linha até Cerqueira César, com uma proposta de prolongamento até Pinheiros. E para oeste, a linha de bonde seguia paralela às linhas férreas Sorocabana e São Paulo Railway em direção à Lapa, e aí finalizando seu trajeto. 
Esses prolongamentos propostos pela Light facilitavam o acesso aos bairros mais afastados do centro da cidade e também interligavam linhas, como no caso da ligação entre as linhas do Pary e do Brás.

Ao observar as linhas propostas pela companhia, é possível notar a formação de um anel de trilhos contornando o centro da cidade, por exemplo, a ligação entre o hipódromo e o Pary. O plano contempla a extensão das linhas até os bairros mais distantes do centro, como Pinheiros e Santana. Ao que parece, as linhas de bondes, em 1905, serviram toda a área urbanizada da cidade com exceção da Vila Prudente, a qual era servida pela estação Ypiranga [sic] por trem. Os nomes dos bairros estão grafados no mapa sobre os arruamentos já existentes, e outros nomes como Hygianópolis, Perdizes, Bom Retiro, Tatuapé, Maranhão e Cambucy [sic] sobre espaços em branco no mapa, estão grafados onde serão formados os futuros bairros, dando a impressão de que o planejamento das linhas de bonde contemplava também a proximidade dos bairros em formação.

Comparando o mapa das linhas de bondes de 1905 com o mapa de 1914, é possível notar que as propostas apontadas no mapa foram realizadas, com exceção das duas linhas para a Aclimação (foi realizada apenas uma); e a linha do Ypiranga [sic] sofre modificações, conectando o bairro à Vila Prudente.

Comparado com o mapa de Gomes Cardim de 1897, vemos que a área da cidade proposta por Cardim é muito semelhante à concretizada em 1905, diferenciando-se apenas no tamanho de alguns loteamentos novos que aparecem com áreas menores em 1905, por exemplo, a Vila Pudente, a Vila Cerqueira César e a Vila Gomes Cardim. 


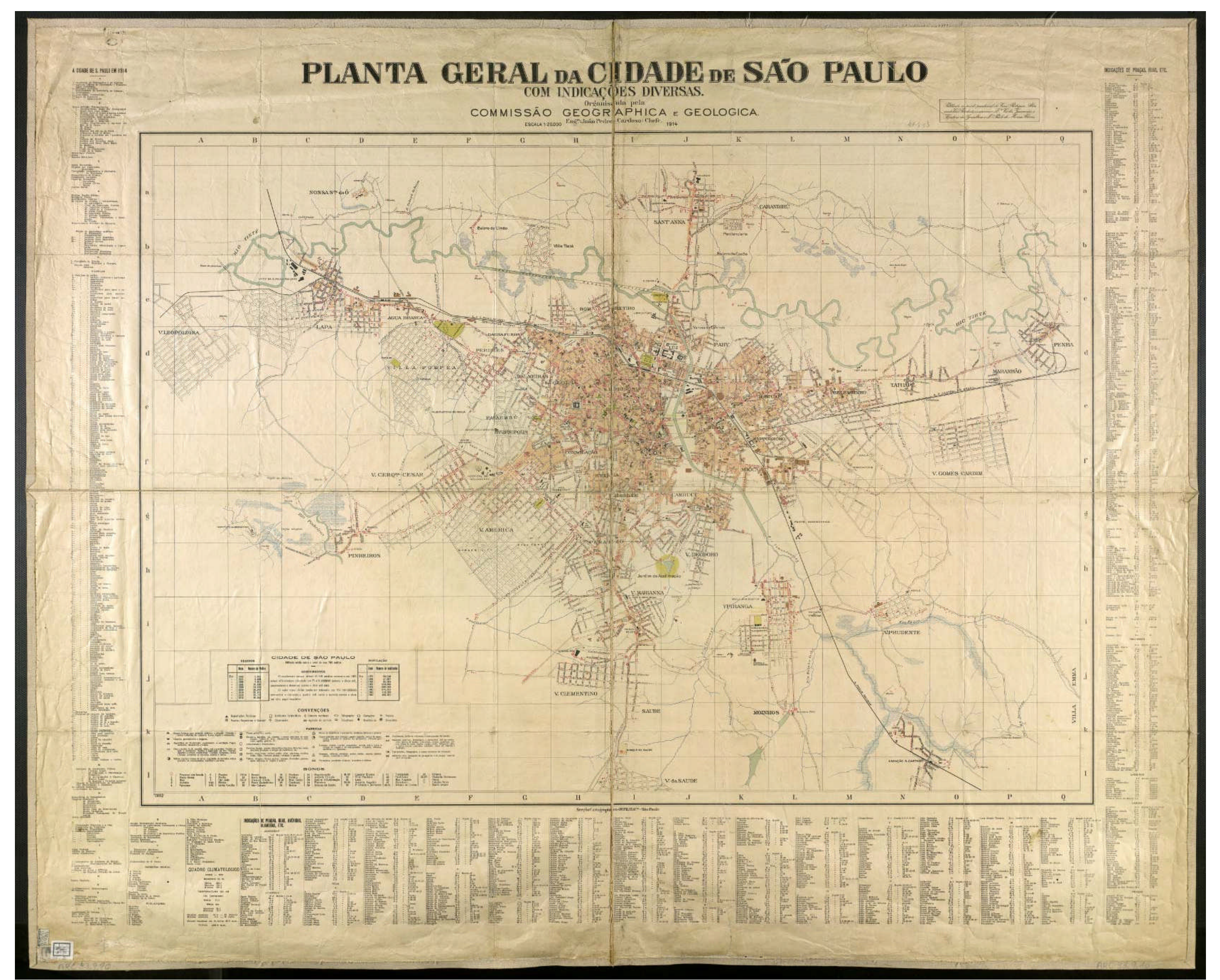

Mapa 11_Planta Geral da Cidade de São Paulo com indicações Diversas- Organizada pela Comissão Geográphica e Geológica 1914 - Engํㅜ chefe João Pedro Cardoso Fonte: Biblioteca Nacional -RJ 


\section{a) Análise cartográfico-iconográfica}

Essa planta mostra uma cidade que se expande além dos limites centrais e inclui os loteamentos mais distantes do centro da cidade com esparsos pontos edificados.

Autoria. A Planta foi organizada pela Comissão Geographica e Geológica ${ }^{45} \mathrm{em}$ 1914, tendo como engenheiro-chefe João Pedro Cardoso. A planta foi elaborada com rigor técnico-científico ${ }^{46}$, apresentando a cidade de forma bem detalhada quanto ao seu tamanho e infraestrutura. Há um quadro no canto superior direito que diz: "Publicada no período presidencial do Cons. ${ }^{\circ}$ Rodrigues Alves, sendo Vice Presidente em serviço Dr. Carlos Guimarães e Secretario da Agricultura Dr. Paulo de Moraes Barros."

Escala, Orientação e Pontos de Referência. A indicação da escala aparece logo abaixo do título e autoria, como escala numérica de 1:20.000. O mapa está orientado para o norte, mas não há referência explícita dessa orientação, a qual foi concluída através da observação da hidrografia. Os principais rios da cidade estão representados na planta, assim como parques e edifícios públicos, que auxiliam como pontos de referência.

Cores, Convenções Cartográficas e Outros Detalhes. A cópia estudada é impressa, e tem fundo branco já um pouco amarelado. A mancha urbana é representada pela cor salmão sob as ruas, e outros elementos, como parques e edifícios, facilitam a visualização da extensão da mancha. Os arruamentos estão representados por quadras com linhas duplas pretas. São adotados diferentes símbolos para representar repartições públicas, escolas, institutos, agências de correio, telefone, telégrafo, garagens, bombeiros, polícia e diversões. Os diversos tipos de fábricas existentes também são representados por símbolos diferentes. As linhas de bonde são numeradas de 1 a 57 na legenda, e, no mapa, esses números são mostrados dentro de círculos na cor vermelha. Há ainda acima da legenda, que está na parte inferior esquerda do mapa, dois quadros que mostram a evolução do número de habitantes na cidade, a partir de 1872, e do número de prédios, a partir de 1840. No canto esquerdo do mapa, há uma legenda que indica praças e ruas e os respectivos bondes por numeração que as servem. No canto direito, são apresentadas informações relativas à cidade no ano de 1914, e uma listagem com

\footnotetext{
45 "Criada em 1886, ainda no Império, a comissão teve como um de seus objetivos o mapeamento da província de São Paulo."(PASSOS, 2009)

${ }^{46}$ Embora não apresente uma malha de coordenadas geográficas.
} 
estabelecimentos comerciais, fábricas, imprensa, quadro climatológico (parte inferior do mapa).

\section{b) Análise iconológica}

Esse mapa é uma representação bem mais complexa, com relação à quantidade de elementos representados, do que os mapas anteriormente analisados. A quantidade de informação no mapa e em suas legendas laterais é bem grande; o uso de símbolos e cores para essas representações já é bem mais complexo nesse mapa do primeiro decênio do século $X X$; isso mostra a evolução das técnicas de mapeamento, assim como o uso de muitas convenções, dando ao mapa uma certa impessoalidade, já que este buscava um padrão técnico.

Um fato muito interessante é o destaque da mancha urbana dado pela cor salmão, diferenciando a área urbana mais adensada (com grande porcentagem de lotes efetivamente ocupados) de outras representadas no mapa. Isso mostra novamente uma cidade em expansão ao se constatar a grande quantidade de arruamentos e de espaços vazios entre tais arruamentos.

No mapa, os bairros como Villa [sic] Pompéia, Lapa, Barra Funda, Vila Leopoldina, Bom Retiro e Belenzinho aparecem em seu estágio inicial e têm suas ruas no sentido paralelo à ferrovia; já a Vila América, atual Jardim América, tem seus arruamentos paralelos à Avenida Paulista, que, nesse mapa, é mostrada com algumas edificações, mas ainda não está inserida na mancha urbana da cidade. Aqui o principal elemento estruturante é a topografia, já que a Avenida Paulista acompanhou o antigo caminho que seguia o divisor de águas; e as transversais foram desenhadas perpendicularmente, segundo o gradiente, e, portanto, tendo a pior configuração em termos de ruas em grande aclive.

Arruamentos do bairro do Ypiranga [sic] formaram-se paralelos à linha férrea Santos- Jundiaí, mas também dispõem de duas linhas de bonde que servem o bairro nas suas extremidades, inclusive ligando-o à Vila Prudente, incluindo um cruzamento e uma conexão com a linha férrea.

Ao sul da cidade, a Vila Clementino cresce, sendo servida, desde o início do século $\mathrm{XX}$, pela linha de bonde do Matadouro. 
Ao norte, acima do rio Tietê, o bairro de Santana é servido pelo tramway ${ }^{47}$ da Cantareira e por uma linha de bonde que segue paralela à linha desse tramway, e seus arruamentos expandem-se a leste e a oeste da linha férrea. Nesse mapa, o bairro de Nossa Senhora do Ó ainda é representado como um núcleo isolado, sem ligações férreas com o centro da cidade; liga-se por caminhos ao bairro do Limão, com edificações bem esparsas.

Comparativamente com os mapas anteriores, é possível perceber o adensamento de alguns bairros como: Tatuapé, Vila Gomes Cardim, Santana, Perdizes, Higienópolis, Ypiranga [sic], Moóca e Vila Prudente. Formaram-se ligações entre Cerqueira César e Pinheiros, Bexiga, Liberdade e Paraíso.

\footnotetext{
${ }^{47}$ Pequena locomotiva a vapor.
} 


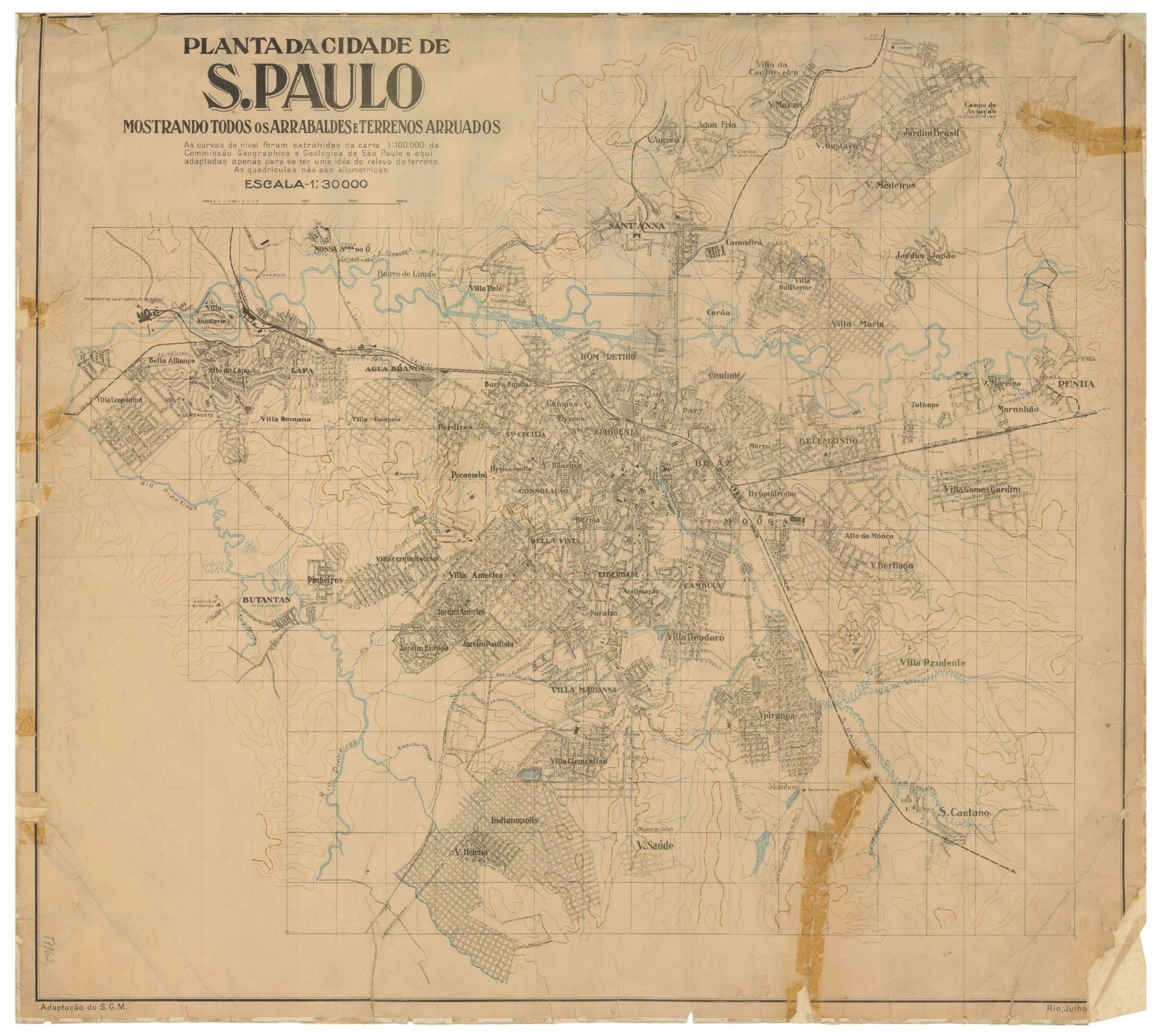

Mapa 12_Planta da cidade de São Paulo- mostrando todos os arrabaldes e terrenos arruados - 1924 Fonte: http://smdu.prefeitura.sp.gov.br/historico demografico/img/mapas/1924.jpg 
Essa planta mostra a cidade de São Paulo na primeira metade do século XX, inclui todos os bairros e arruamentos existentes, e representa os principais rios e afluentes da hidrografia paulistana. Dos mapas selecionados, é o primeiro que apresenta curvas de nível bem definidas em toda a sua extensão.

\section{a) Análise cartográfico-iconográfica}

Autoria. Não há referência à autoria dessa planta, no entanto serve a propósitos municipais de planejamento. A cópia atualmente faz parte do Acervo do IGC Instituto Geográfico Cartográfico, conservado no Arquivo Histórico do Estado de São Paulo.

Escala, Orientação e Pontos de Referência. A escala numérica mostrada no mapa é de 1:30.000, e, logo abaixo, há uma escala gráfica em metros dividida em 4 partes de 1000 metros. A planta não possui seta de orientação, mas, através da hidrografia bem detalhada, pode-se presumir que está orientada para o norte. São representados rios, córregos e corpos de água, parques e edifícios, além dos bairros, que podem ser adotados como pontos de referência. Há uma quadrícula representada na planta, mas, como explica a nota abaixo do título, não é quilométrica; As quadrículas não trazem informação das coordenadas geográficas.

Cores, Convenções Cartográficas e Outros Detalhes. O mapa é impresso em papel vegetal já amarelado. Não há legenda com convenções cartográficas, porém, são adotadas convenções padronizadas, como as atuais: curvas de nível em sépia, hidrografia e várzeas na cor azul, linhas férreas representadas por duas linhas paralelas em branco e preto, e as estações férreas, representadas em preto. As ruas são traçadas em preto. Os loteamentos arruados aparecem no mapa como ruas sem nome, por exemplo, o bairro de Indianópolis. O mapa possui explicação abaixo do

título "As curvas de nível foram extrahidas da carta 1:100.000 da Comissão Geographica e Geologica do Estado de São Paulo e aqui adaptadas apenas para se ter uma idéia do relevo do terreno." 


\section{b) Análise iconológica}

Dos mapas analisados, esse é o primeiro a apresentar as curvas de nível ${ }^{48}$. O mapeamento hidrológico também se mostra bem completo, o que leva a crer que esse mapa também foi utilizado para o planejamento da cidade.

O mapa de 1924 mostra uma cidade com seus limites bem mais expandidos que nas plantas anteriores, com menos espaços vazios entre os bairros, e, ao norte, cruzando o rio Tietê, mostra bairros novos como Água Fria, Vila Guilherme, Jardim Brasil, Villa Mazzei [sic], Villa da Cachoeira [sic], Vila Aurora, Villa Tietê [sic], Bairro do Limão e Vila Maria.

Ao oeste, são apresentados bairros que não apareciam nos anteriores, como Vila Romana, Vila Leopoldina, Bella Alliança, Alto da Lapa, Villa Pompéia [sic] e Vila Anastácio, que tem seus arruamentos paralelos à linha férrea Sorocabana. $\mathrm{O}$ bairro de Pinheiros já não aparece mais como núcleo isolado, mas está ligado ao bairro de Cerqueira César; seguindo a direção do bairro de Pinheiros, aparece a área de várzea do Butantan [sic].

Ao sudoeste, são mostrados arruamentos dos bairros de Villa América [sic], Jardim América, Jardim Europa e Jardim Paulista. Estes são representados com os arruamentos contíguos uns aos outros.

A sudeste, os bairros de Vila Clementino, o arruamento de Indianópolis e de Vila Helena são traçados com suas ruas paralelas à linha do bonde em direção a Santo Amaro. Ainda, o bairro do Ypiranga [sic] tem suas ruas aumentadas, seguindo padrão de tabuleiro de xadrez, acompanhando os ramais do bonde.

Ao leste, bairros como Moóca, Belenzinho, Tatuapé se expandem, em Alto da Moóca e Vila Bertioga, e têm suas áreas aumentadas; os bairros de Maranhão e Vila Moreira estão contíguos ao do Tatuapé, e seguem o sentido da linha de bonde Penha que foi traçada paralela à linha férrea São Paulo-Rio de Janeiro.

A cidade se expande seguindo o processo já iniciando no final do século XIX, nas linhas propostas pelo mapa de Gomes Cardim de 1897.

48 A planta de São Paulo feita por Carlos Rath em 1955 apresenta algumas informações sobre topografia da cidade para embasar seus estudos hidrológicos. 


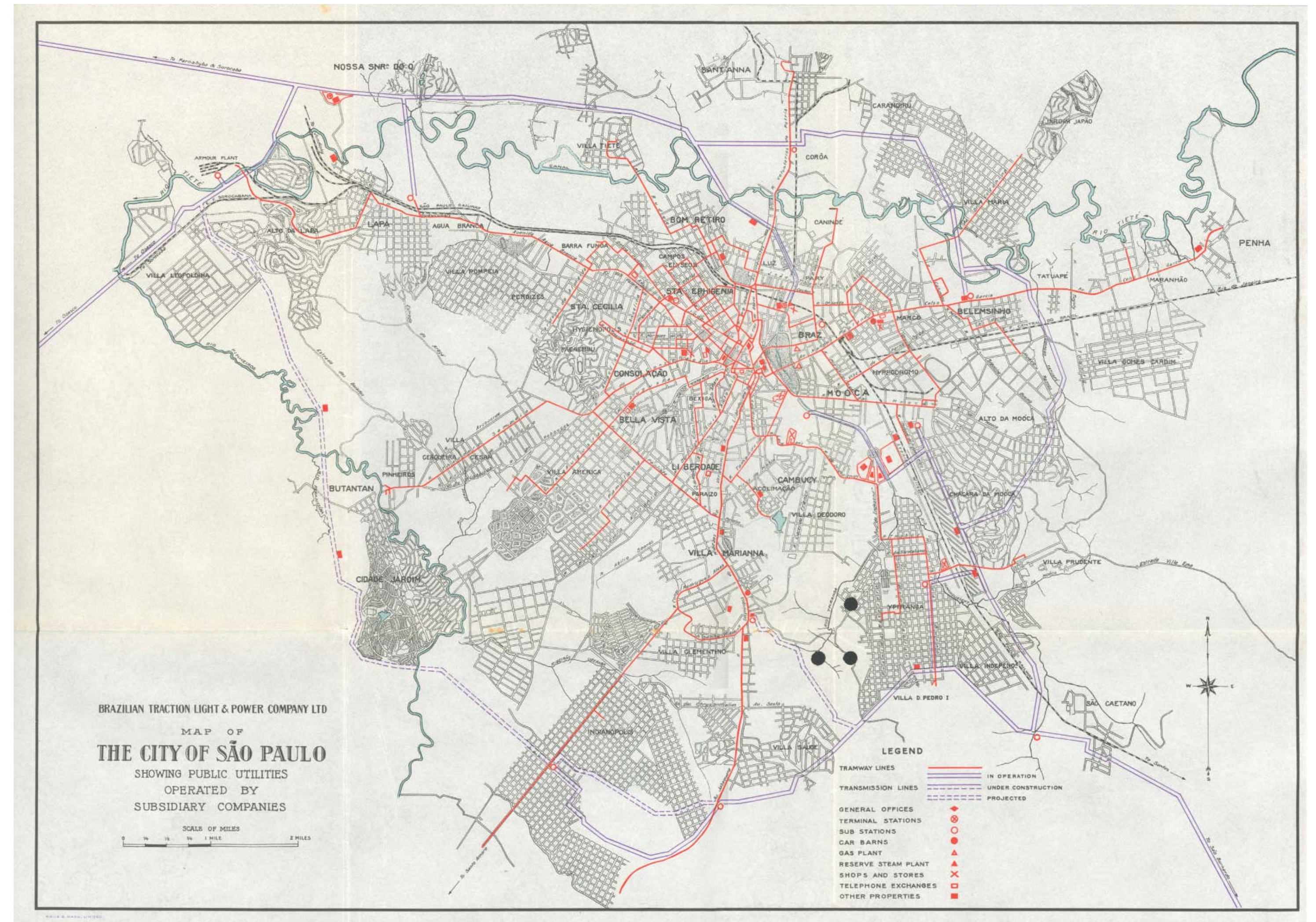

Mapa 13_Map of the city of São Paulo Showing Public Utilities Operated by Subsidiary Companies - 1924

Fonte: Acervo Fundação Energia e Saneamento 


\section{a) Análise cartográfico-iconográfica}

Autoria. Brazilian Traction Light \& Power Company Limited, holding criada em 1912 que tinha como empresas subordinadas as duas canadenses: The Sao Paulo Tramway Light \& Power Company e a The Rio de Janeiro Light \& Power Company. (SZMRECSÁNY, 1986).

Escala, Orientação e Pontos de Referência. Escala gráfica em milhas, coerente com o sistema inglês. Possui seta apontando para o norte em direção à margem superior do mapa; possui como pontos de referência o Rio Tietê e as linhas férreas.

Cores, Convenções Cartográficas e Outros Detalhes. O mapa é colorido, possui fundo branco, ruas e quadras representadas em preto, a hidrografia em azul e as linhas de bonde em vermelho; as linhas de transmissão elétrica estão representadas em roxo, com linha contínua para as já existentes e linha tracejada para as projetadas. A legenda é composta por desenhos geométricos em vermelho, que representam escritórios, estações terminais, subestações, estacionamento dos bondes, estações de gás, lojas e outras propriedades. Nessa planta, que representa a cidade de São Paulo com os limites da época, pode-se observar uma grande generalização no centro da cidade, pois quase não há distinção com nomes de ruas; apenas as principais são nomeadas em toda a planta, dando a ela um caráter de instrumento de planejamento para fins específicos.

\section{b) Análise iconológica}

Esse mapa foi elaborado pela holding, formada basicamente pela Light, que controlava as operações de bondes e de energia elétrica na cidade de São Paulo.

Mostrando não somente as linhas de transmissão elétricas existentes e projetadas, esse mapa traz também subestações, terminais, plantas de reserva de gás e de vapor, comércio, garagem de trens e centrais telefônicas. Importantes são as linhas de bondes, que mostram uma evolução, um crescimento com relação à situação mostrada no mapa de 1905.

Em termos de bairros que são representados e de tamanho da cidade, o mapa não traz a distinção de área urbanizada ou de arruamentos; acrescentou-se o bairro de Cidade Jardim na margem esquerda do rio Pinheiros.

Provavelmente, como seu uso era para planejar o fornecimento de serviços; a mancha urbana não distingue entre arruamentos ocupados e os planejados. 
Observa-se que, devido aos prolongamentos, a rede de transporte de bondes mostra-se mais como uma irradiação a partir do centro da cidade para as extremidades, as quais são servidas por linhas únicas, passando nas proximidades do centro dos bairros; existem também as linhas que são paralelas aos trilhos do trem. E no centro expandido da cidade ${ }^{49}$, na época, as linhas de bondes interligamse, formando uma rede circular.

${ }^{49}$ Considerando como limites os bairros Liberdade, Moóca, Brás, Campos Elíseos, Barra Funda, Consolação e Bela Vista. 


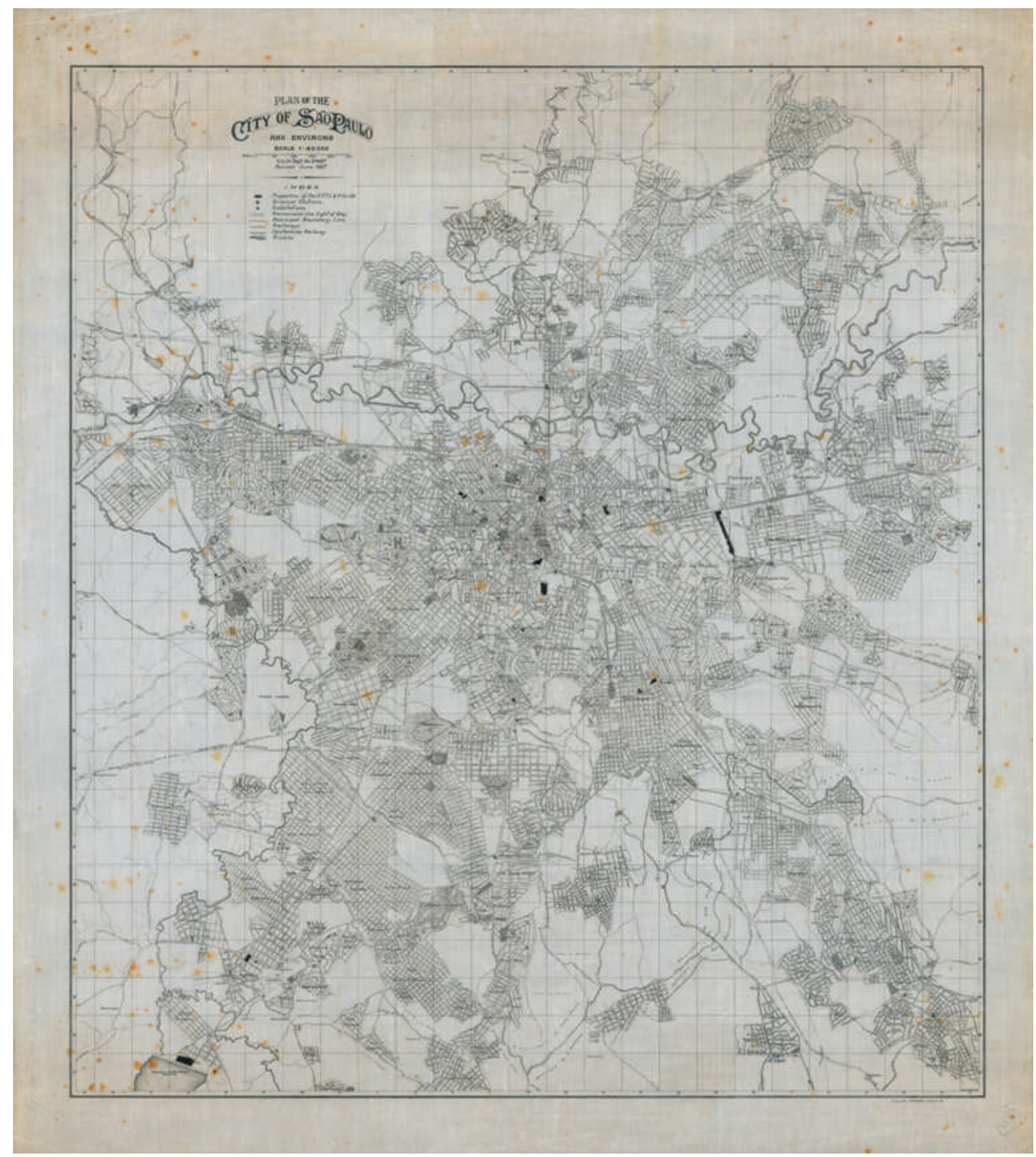

Mapa 14_Plan of the City of São Paulo and Environs_1927

Fonte: Acervo Fundação Energia e Saneamento

\section{a) Análise cartográfico-iconográfica}

Autoria. Brazilian Traction Light \& Power Company Limited, holding criada em 1912 que tinha como empresas subordinadas as duas canadenses: The Sao Paulo Tramway Light \& Power Company e a The Rio de Janeiro Light \& Power Company. (SZMRECSÁNY, 1986). 
Escala, Orientação e Pontos de Referência. O mapa apresenta escala numérica de 1:40000, e também escala gráfica de 500 metros. Não há seta de orientação ou rosa dos ventos desenhada no mapa. Seus pontos de referência são os rios Tietê e Pinheiros, assim como as linhas férreas, que tomadas dessa forma, apontam numa orientação para o norte.

Cores, Convenções Cartográficas e Outros Detalhes. Essa cópia do mapa parece estar reproduzida sobre um tecido, pois é possível, ao ampliar a imagem, ver a trama do tecido, provavelmente branco, mas já amarelado, e com manchas cor de ferrugem; os elementos são representados na cor preta e o mapa é preto e branco. O mapa traz representadas as propriedades da The Sao Paulo Tramway Light \& Power Company, os terminais, as subestações, as linhas de transmissões existentes, as ferrovias, os limites municipais, o trem da Cantareira e os rios. As convenções utilizadas são: figuras geométricas para representar as propriedades, terminais e substações e linhas tracejadas, ou duplas, diferenciadas, para representar as linhas férreas, as de tramway de transmissão e os rios. O mapa apresenta uma rede quadricular definida por letras na horizontal e por números na vertical, um sistema que é utilizado ainda nos dias atuais para localização de ruas em guias e em plantas.

\section{b) Análise iconológica}

O mapa representa a cidade de São Paulo até os seus limites com outros municípios como São Bernardo, Santo Amaro ${ }^{50}$, Guarulhos e Osasco. Esse foi o último mapa selecionado para estudo, porque apresenta a cidade expandida para todas as direções, inclusive com os bairros alcançando seus limites municipais.

A represa do Guarapiranga, denominada no mapa Repreza de Sto. Amaro (sic), aparece destacada na margem inferior do mapa.

Como os outros mapas elaborados pela Companhia Light, seu caráter funcional de planejamento transparece por mapear a cidade de forma abrangente para, talvez, suprir demandas futuras de energia e para gerenciar seus ativos de propriedades.

Esse mapa tem como característica principal mostrar a cidade na sua expansão, localizando elementos que interessavam à holding da Light, que o produziu, como linhas de transmissão e subestações, os rios e as linhas de bondes. A companhia

\footnotetext{
${ }^{50} \mathrm{Na}$ data da elaboração do mapa era município independente de São Paulo.
} 
oferecia uma solução integrada de energia e transporte para a cidade, e, a partir desta data (1927), permite também que o Reservatório do Guarapiranga, localizado em Santo Amaro, representado no mapa, inicialmente criado para a geração de energia elétrica, seja também utilizado para o abastecimento de água da cidade.

Nesse mapa, são inúmeros os acréscimos de bairros; ao norte, os bairros aparecem interligados, e se estendem até o limite municipal. O bairro de Vila Maria é dividido por duas nomenclaturas: V. Maria alta e V. Maria baixa. Surgem bairros como Villa [sic] D. Pedro II, Villa [sic] Pedroza, Villa [sic] Éde, Tucuruvi, Villa [sic] Medeiros, Villa [sic] Gustavo, Villa [sic] Nova Mazzei, Tremembé e Parque Mandaqui.

A oeste surge o bairro de Vila Jaguaribe. A Cidade Jardim aparece menos ampla que no mapa de 1924.

E ao sul estão representados os bairros de Villa [sic] Olympia, Ibirabuera, Vila Conceição, Mirandópolis, Vila Gumercindo, Villa [sic] Guarani e Parque Imperial.

Alguns atuais bairros estão inseridos no então município de Santo Amaro; destacam-se Brooklin Paulista I e II, Jardim Petrópolis, Chácara Monte alegre, Villa [sic] Santa Catarina, Americanópolis, Villa [sic] Mascote, Parque Jabaquara, Chácara Flora, Santo Amaro e Vila do Socorro.

Os bairros Ypiranga [sic] e Vila Prudente expandem-se, unindo-se, respectivamente, ao Cambuci e à Moóca.

Ao leste, destacam-se os bairros novos de Villa [sic] Emma, Villa [sic] Carrão, Villa Formoza [sic], Água Rasa, Vila Matilde e Vila Aricanduva. O núcleo da Penha também foi expandido; no mapa, são representados os bairros da Villa [sic] Esperança, Villa [sic] S. Anna e Villa [sic] Marietta.

Percebe-se que a conformação da cidade e seus limites já estão bem próximos dos atuais, excetuando-se a zona sul e o adensamento dos bairros. Como a ênfase deste estudo foi colocada na área central da cidade, e em sua expansão, esse mapa pode ser utilizado como limite do estudo, pela data e sua criação e pela conformação da cidade nele representada. 


\section{Resultados}

Neste capítulo serão apresentados os mapas que resultaram do uso da cartografia digital e dos Sistemas de Informações Geográficas, buscando sustentar visualmente o processo de expansão da mancha urbana de São Paulo com mapas do período de 1847 a 1927 além de demonstrar cartograficamente o crescimento da rede de trilhos durante o processo de estruturação da cidade.

Ao longo das análises dos mapas históricos feitas no capítulo 7 foi possível notar que a cidade expandiu se em quase todas as direções e que os trilhos principalmente de bondes foram prolongados ao longo dos anos.

Os resultados da pesquisa buscam embasar a hipótese apresentada inicialmente na qual os trilhos (bondes e trens) apresentaram-se como um dos principais elementos estruturantes do crescimento da cidade, atuando em conjunto com a implantação dos sistemas de água, esgoto, gás e energia elétrica.

Algumas dessas interações da infraestrutura de água, energia e drenagem de várzea com os trilhos já foram destacadas no capítulo 7 por meio das análises iconológicas dos mapas.

\subsection{Mapas temáticos}

Como explica (MARTINELLI, 2003) "Podemos considerar que a elaboração do mapa temático da Geografia se insere num contexto que envolve a busca do conhecimento e o esclarecimento acerca de certa questão da realidade que se tem interesse em resolver."

Um conjunto de mapas temáticos apresentados de forma temporal permite a análise de um determinado fenômeno ao longo do tempo, no caso do estudo da cidade o tema explorado nos mapas a seguir foi a expansão da mancha urbana.

Serão apresentados os mapas da expansão da mancha urbana de São Paulo dos anos de 1847, 1868, 1881, 1890, 1897, 1905, 1914, 1924 e 1927 respectivamente, de modo a permitir uma análise do crescimento da cidade como um todo.

A da mancha urbana de 1847 estava em sua maior porção entre o triângulo central da cidade tinha como vértices os rios Anhangabaú e Tamanduateí e como limite sul às imediações da Rua Tabatinguera na Liberdade correspondendo a uma área de 
tamanho igual à $1,35 \mathrm{Km}^{2}$. Além dessa mancha principal ainda há a atual região da Luz que na data possuía os edifícios da Casa de correção, o Convento da Luz o Hospital dos Lázaros e o Jardim Botânico atual Jardim da Luz constituindo uma mancha urbanizada isolada da mancha principal com área igual a $0,36 \mathrm{Km}^{2}$. Assim considerando as duas manchas como áreas urbanizadas o valor total da área urbanizada é de $1,70 \mathrm{Km}^{2}$.

Além da área edificada mostrada no mapa ainda são representados lotes ou chácaras com uma edificação isolada ou sem edificação próximos a mancha urbana neste mapa essas manchas estão localizadas na atual região da República incluindo a Praça da República nomeada no mapa de Campo do Curro em direção ao Bom Retiro, no Brás onde encontravam a Chácaras do Brésser e do Bispo essas estavam localizadas no caminho para a Moóca e para acessa-las a partir do centro era necessário atravessar a várzea do Tamanduateí e no mapa estão representadas três pontes em direção a esse caminho: Ponte do Carmo, Ponte do Meio e Ponte do Ferrão. A outra mancha isolada aparece na Moóca próximo a ponte de Tabatinguera na Estrada da Moóca que levava ao Rio de Janeiro. A área dessas manchas somadas é igual a $1,74 \mathrm{~km}^{2}$.

Os mapas 15 e 16 apresentados a seguir mostram à mancha urbana de São Paulo em 1847, o mapa 15 foi elaborado sobre a base do mapa original e o mapa 16 sobre a base atual de distritos. 


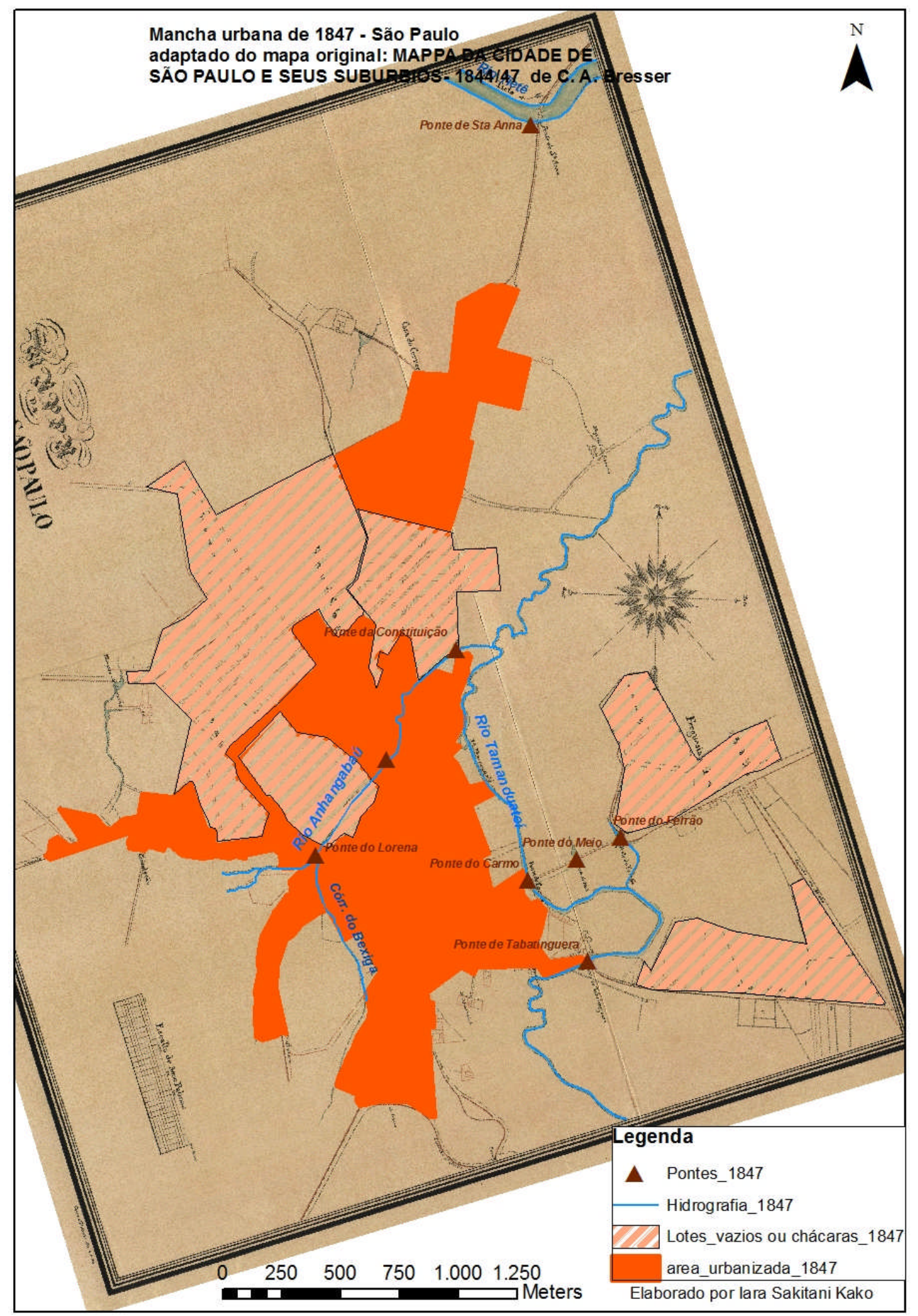

Mapa 15_Mancha Urbana de São Paulo em 1847 sobre mapa original 


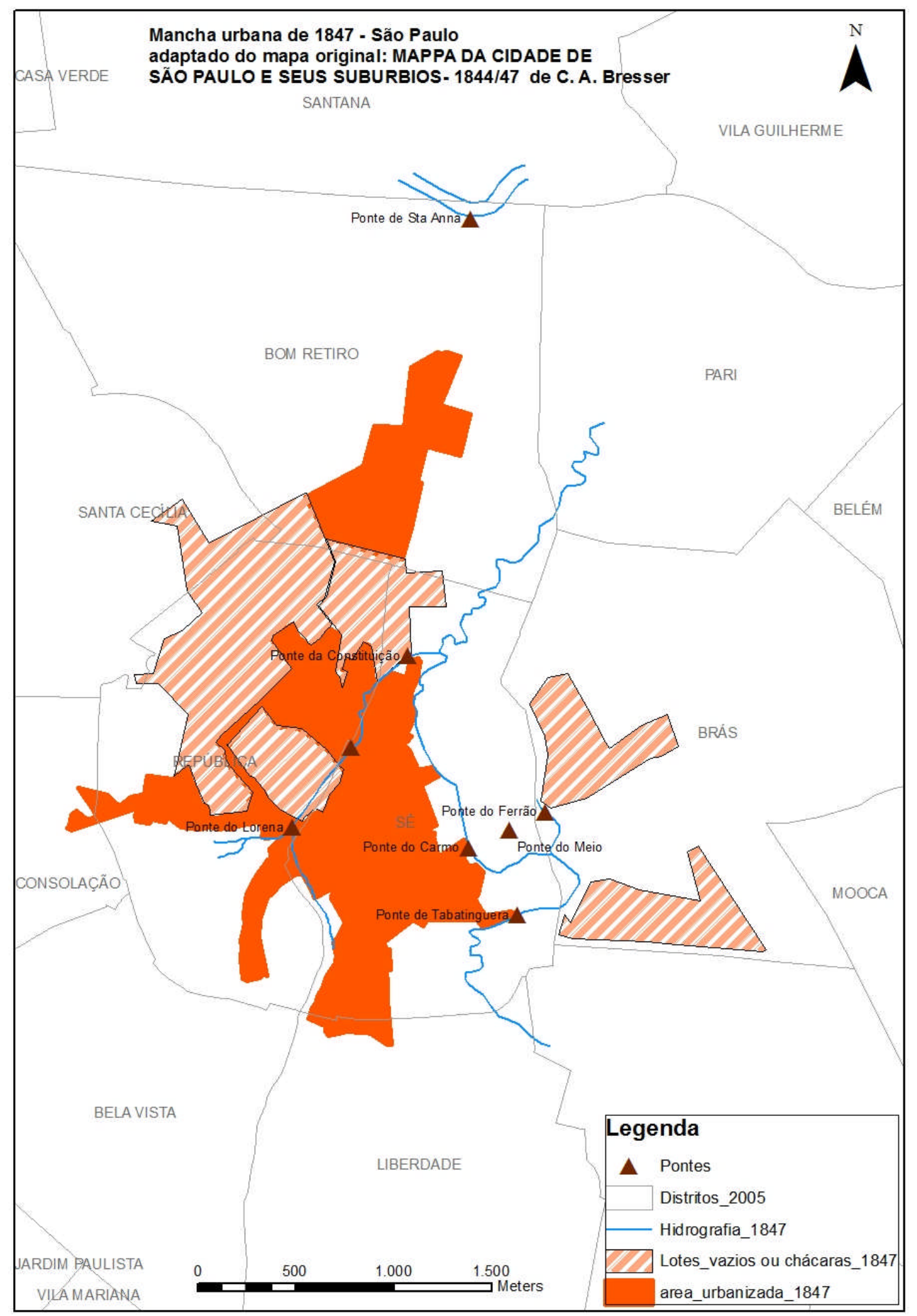

Mapa 16_Mancha Urbana de São Paulo em 1847 com divisão distrital atual 
O mapa da Carlos Rath de 1868 é o primeiro mapa da seleção a mostrar o traçado da recém implantada linha férrea que ligava Santos a Jundiaí que foi inaugurada no ano anterior ao mapa 1867.

A área urbanizada mostrada por Rath em seu mapa compreende em uma área de 2,7 Km² concentrada, como no mapa anterior, no triângulo central com uma discreta expansão para o noroeste em direção ao Bom Retiro, República e Santa Cecília. Nesse mapa a região da Luz apesar de pouco adensada foi representada de forma contígua a mancha central.

Os loteamentos ainda não ocupados foram traçados no mapa em um tom mais claro que aqueles efetivamente ocupados possibilitando sua identificação. Para esses loteamentos os próximos ao centro da cidade a soma de suas áreas é igual a 1,67 $\mathrm{km}^{2}$ calculados sobre o mapa.

Esses loteamentos são cinco e estão nas seguintes regiões: Norte da República, República, Bom Retiro, Liberdade e Brás. Ao comparar esses novos loteamentos com os que apareceram no mapa de 1847 nota-se que a ocupação do Bom Retiro nas proximidades da Luz tornou se efetiva ligando a região do então Jardim Botânico com o centro e tendo a ferrovia como um divisor. Parte da região da República foi efetivamente urbanizada e parte ainda permaneceu em forma de loteamento, este seria o atual quadrilátero das ruas Aurora e Duque de Caxias, Av.Rio Branco e Rua Mauá. Na Liberdade o loteamento traçado corresponderia atualmente a Rua dos Estudantes, Av. do Glicério, Rua da Glória e Av. Lavapés ${ }^{51}$. As chácaras do Brás próximas à estrada da Móoca ${ }^{52}$ que apreciam no mapa de 1847 continuam ainda sem arruamentos nesse mapa.

A seguir os mapas 17 e 18 apresentam a mancha urbana de 1868 e seus loteamentos, assim todos os aspectos destacados no trecho acima podem ser visualizados nos respectivos mapas.

\footnotetext{
51 Denominada no mapa de 1868 como "Caminho Velho"

52 Denominada no mapa de 1868 de "Caminho da Tabatinguera".
} 


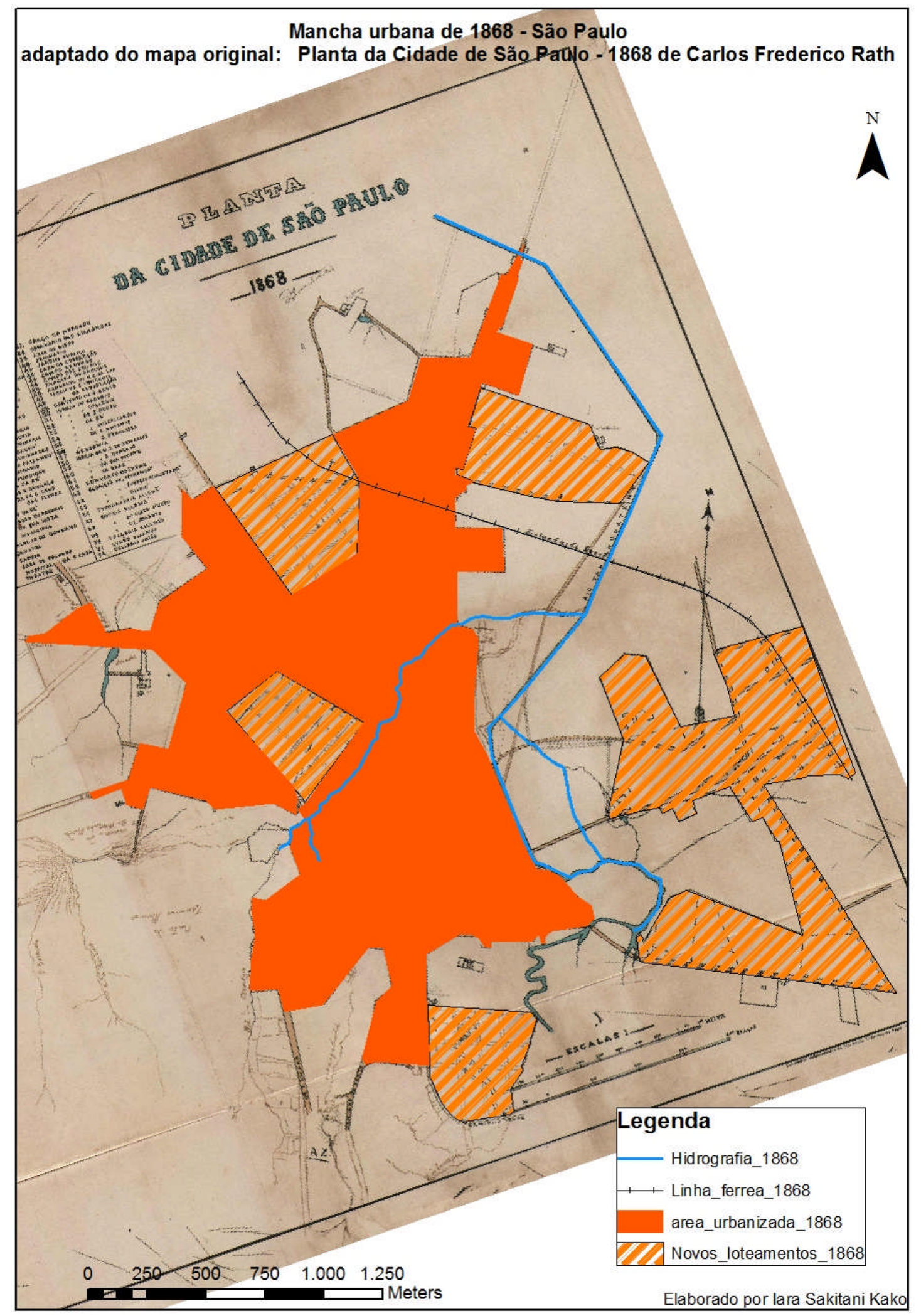

Mapa 17_Mancha Urbana de São Paulo em 1868 sobre mapa original 


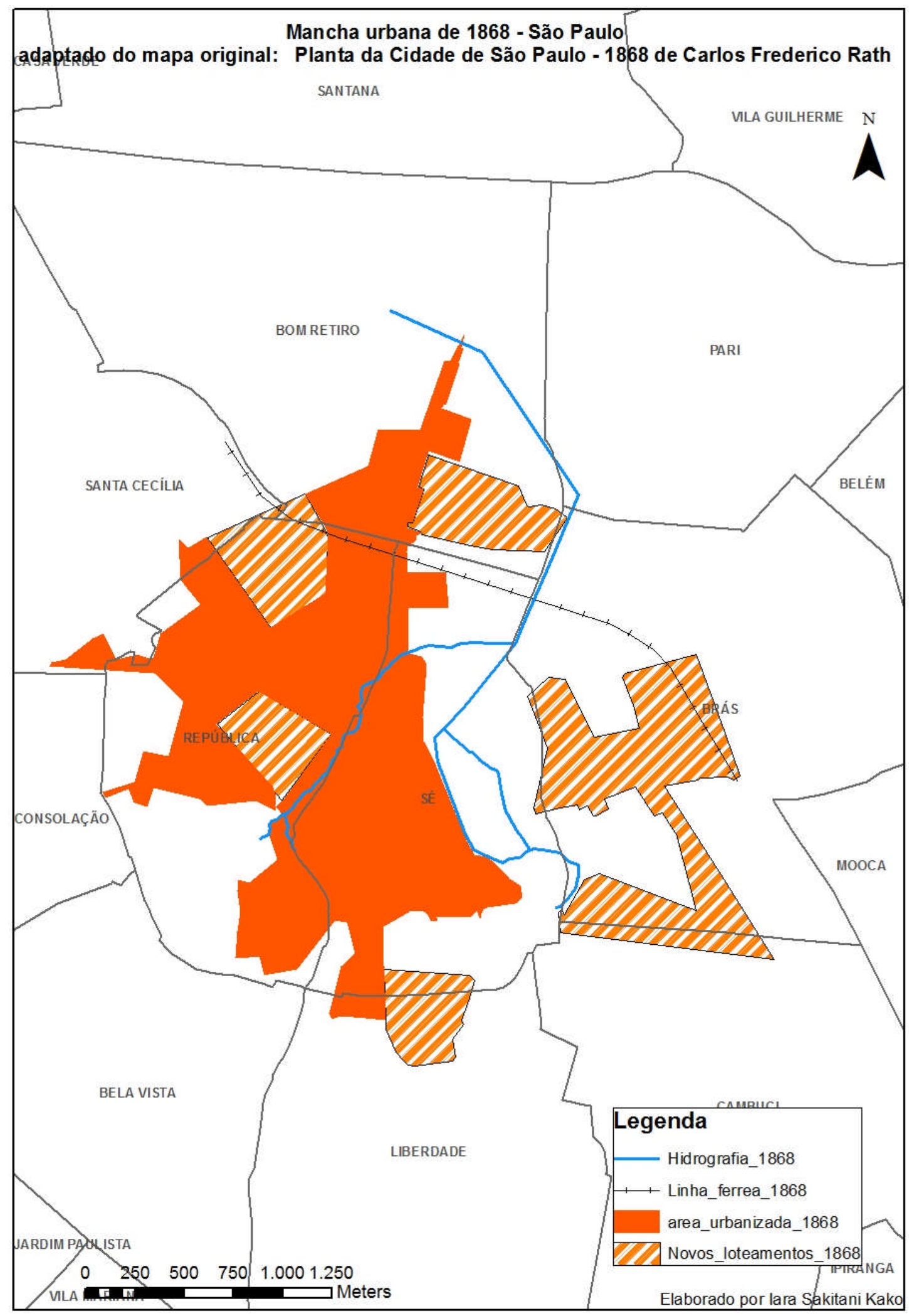

Mapa 18_Mancha Urbana de São Paulo em 1868 com divisão distrital atual 
Nas últimas décadas do século XIX o sistema de abastecimento de água da cidade começou a ser modificado, a Cia Cantareira de Esgotos criada em 1877 era a empresa responsável pelo novo sistema de abastecimento de água que utilizaria adutoras e novas caixas de abastecimento municipais para trazer a água da Serra da Cantareira e distribuí-la na cidade, substituindo gradativamente os chafarizes por encanamentos e torneiras domiciliares. Em 1893 esse serviço passou para o governo do Estado e foi criada a Repartição de Águas e Esgotos. (BRUNO, 1984) (JORGE, 2003)

O mapa 19 mostrado logo a seguir teve como base o mapa elaborado pela Cia Cantareira de Esgotos em 1881 e mostra a mancha urbana da cidade nessa data.

A sua área urbanizada era igual $3,7 \mathrm{Km}^{2}$ e os três novos loteamentos: no Brás ao norte da estação de trem, em direção a Bela Vista e o último em direção a Santa Cecília nas proximidades da linha férrea Sorocabana totalizando 1,6 km² de área.

Em 1881 as três linhas férreas que cruzam a cidade já estavam em funcionamento. As estações das linhas representadas no mapa eram três: estação da Luz, estação do Braz e estação do Norte.

As obras de retificação e aterros são representadas no mapa como aterrado do Braz e aterrado do Gasômetro onde funcionava a fábrica de gás, descrita na legenda do mapa de 1881.

Apesar de não mostradas no mapa de 1881, as linhas de bondes a tração animal já estavam circulando pela cidade desde 1872, e ligavam o centro da cidade com as estações de trem.

Se comparado com o mapa anterior de 1868 a área urbanizada da cidade expandiu em direção ao Brás nas proximidades das estações do Brás e do Norte, no mapa anterior essa porção da cidade era ocupada por chácaras

Em 1877 (MORSE, 1970) descreve a venda de lotes de 30 metros $^{53}$ ao longo de uma linha de bondes projetada para o bairro da Liberdade. O autor descreve também o loteamento do bairro de Campos Elíseos pelo alemão Frederico Glette no ano de 1879, esse loteamento é representado no mapa de 1881 como arruamentos anexo a linha férrea no atual distrito de Santa Cecília, pode ser observado no mapa 20 a seguir.

\footnotetext{
${ }^{53} \mathrm{O}$ autor não explica se esses 30 metros eram a medida da frente do lote, para maiores detalhes ver (MORSE, Formação Histórica de São Paulo (De Comunidade à Metrópole), 1970) página 248 e 249.
} 


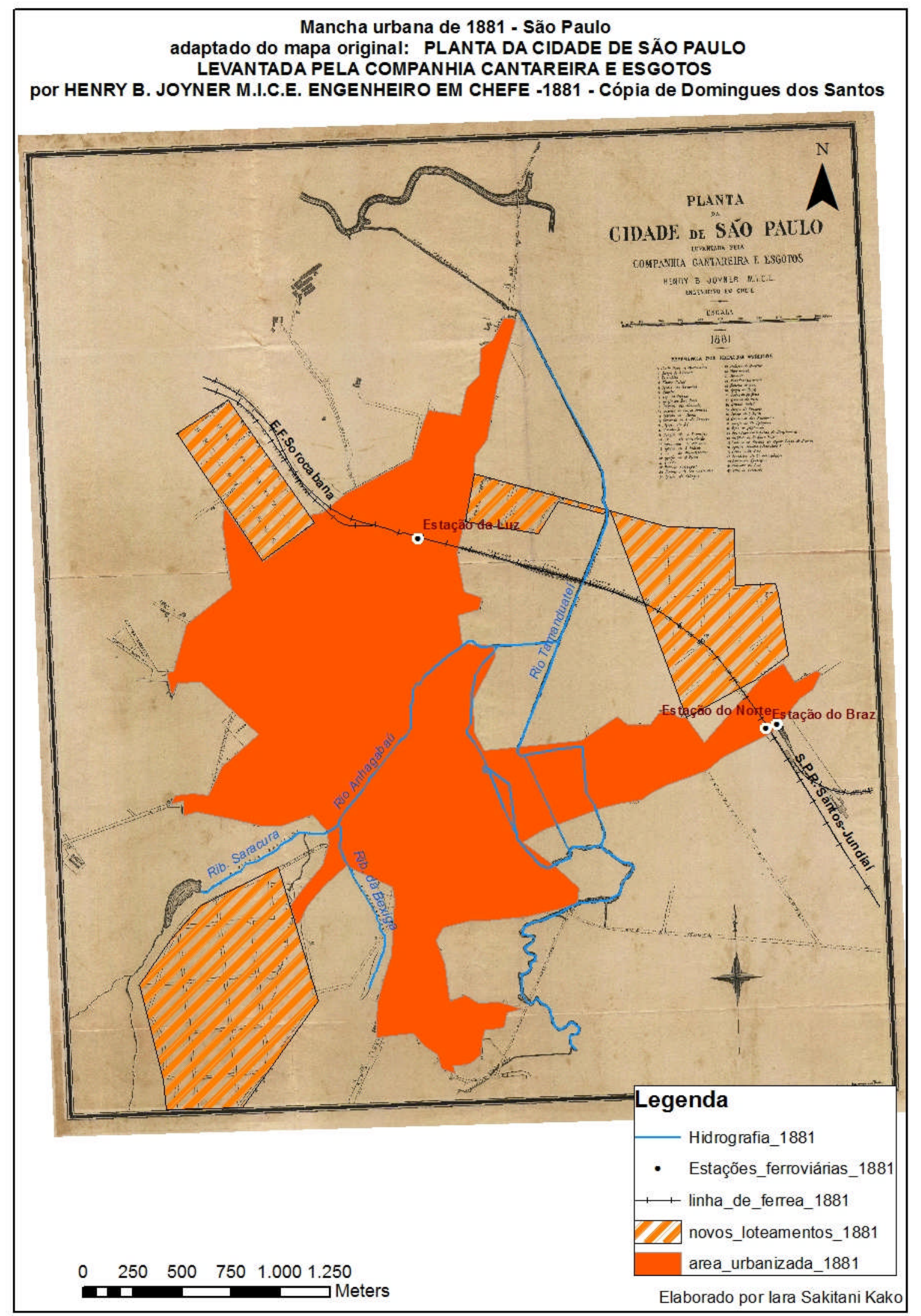

Mapa 19_Mancha Urbana de São Paulo em 1881 sobre mapa original 


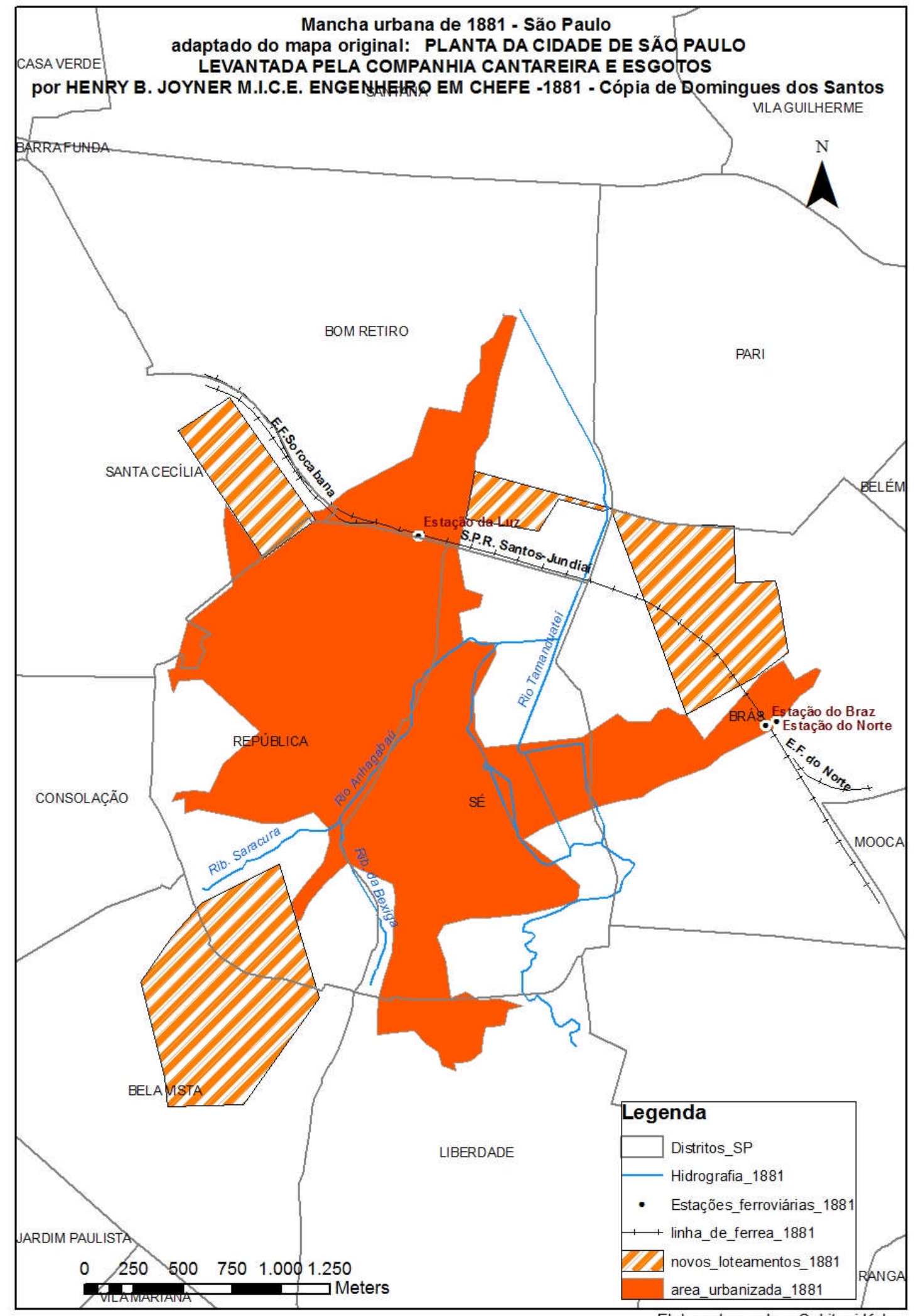

Elaborado por lara Sakitani Kako

Mapa 20_Mancha Urbana de São Paulo em 1881 com divisão distrital atual 
São Paulo possuía 64.934 habitantes em 1890, ou seja, 107\% a mais do que em 1872. Sua população mais que dobrou em apenas 18 anos esse crescimento acelerado causava preocupação ao Estado que tentava sanar os problemas da cidade. Porém como descreve (MORSE, 1970, p. 251):

As autoridades estavam mal aparelhadas para esta pressão do crescimento. As utilidades públicas não poderiam expandir-se com suficiente rapidez. Eram insuficientes a limpeza e pavimentação das ruas, os serviços de lixo e esgotos, a drenagem das baixadas.

A mancha urbana da cidade de São Paulo em 1890 mostra o resultado da expansão descrita acima, no mapa de 1890 desenhado por Jules Martin não há diferenciação entre novos loteamentos e áreas efetivamente ocupadas. A região onde hoje estão localizados os distritos da Sé e Republica aparece quase que totalmente ocupada com exceção das áreas de várzea do Rio Tamanduateí e do córrego do Bexiga afluente do Rio Anhagabaú.

Outra área de várzea sem ocupação e que é mostrada no mapa de $1890 \mathrm{sem}$ ocupação está ao norte do distrito do Cambuci no quadrilátero formado pelas atuais ruas: Tabatinguera, da Glória, Lavapés e Luis Gama.

Nas proximidades da Estação do Norte e do Braz as ruas surgem no sentido paralelo a linha do trem, numa distância de 600 metros da estação na direção oeste da linha e esse traçado de ruas é limitado pela várzea do Carmo.

A área da mancha urbana mostrada no mapa de 1890 é igual a $12,4 \mathrm{~km}^{2}$ valor que significa um aumento de $127 \%$ sobre a área urbana calculada no mapa anterior que era igual a $5,3 \mathrm{~km}^{2}$.

A seguir os mapas 21 e 22 mostram a mancha urbana de 1890 sobre o mapa original e sobre o mapa com a divisão distrital de São Paulo. As áreas de várzea não ocupadas aparecem no mapa como polígonos de cor mais clara que a mancha urbana. È possível notar uma urbanização mais efetiva nas proximidades das linhas férreas, nos bairros da Luz, Pary, Campos Elíseos, Bom Retiro e Braz. 


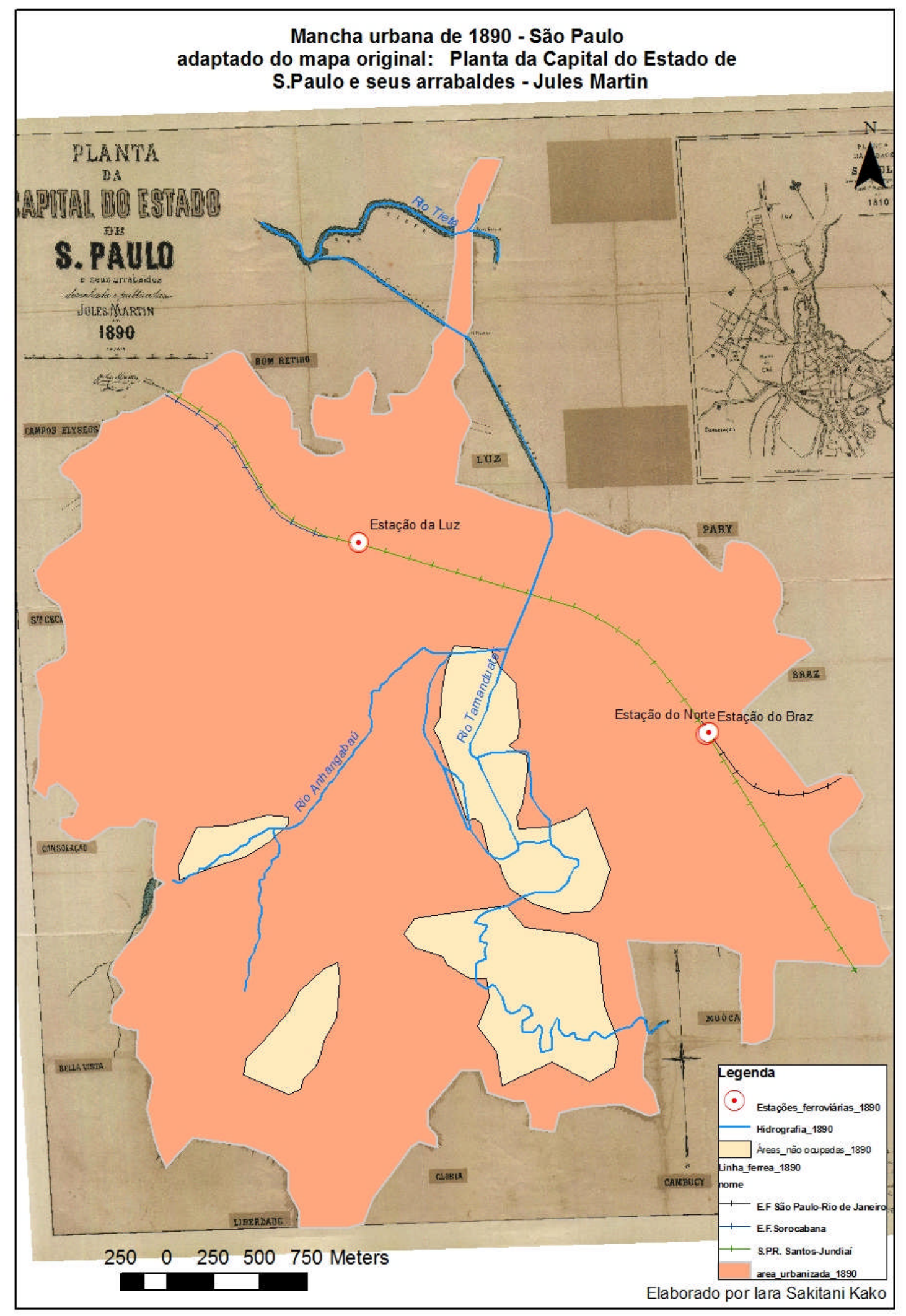

Mapa 21_Mancha Urbana de São Paulo em 1890 sobre mapa original 


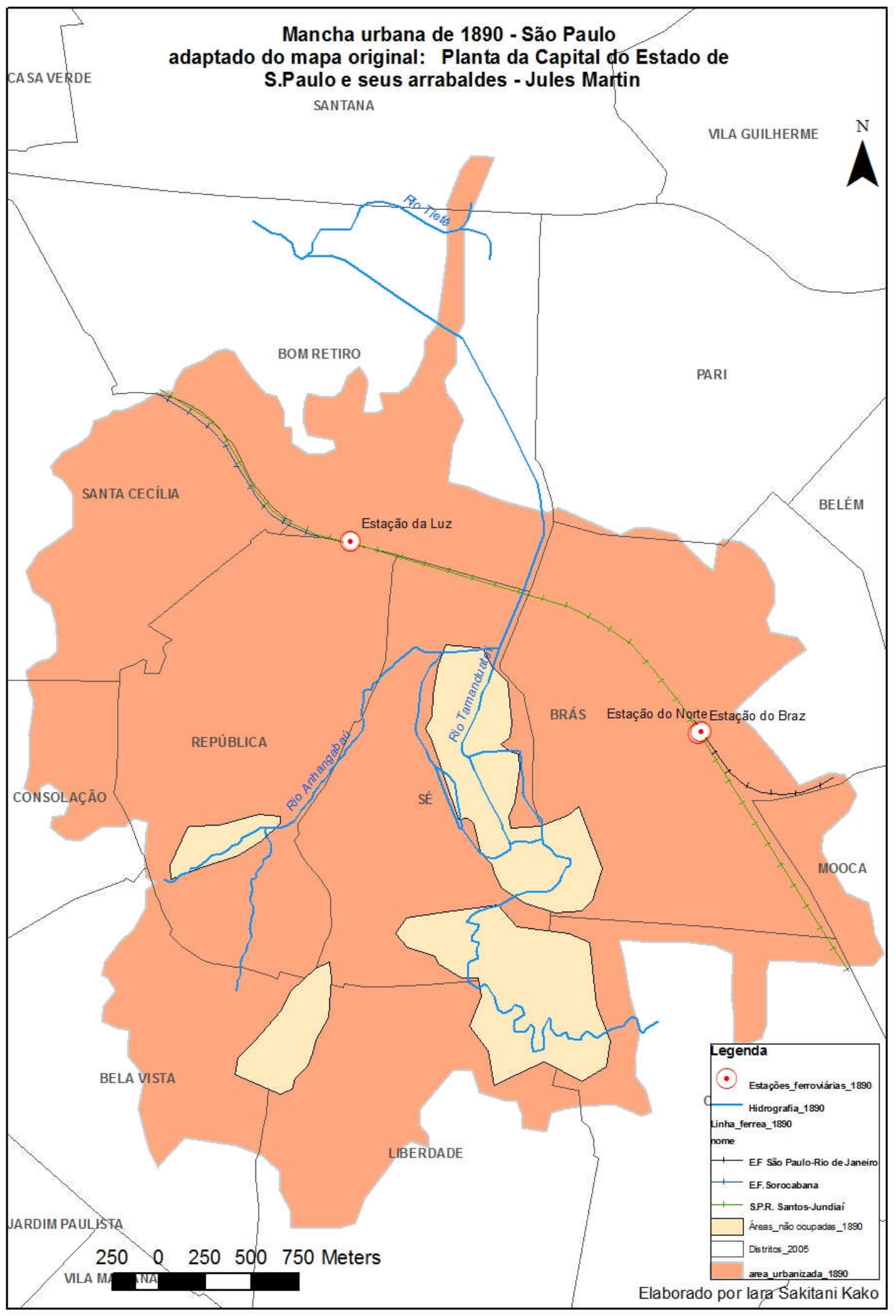

Mapa 22_Mancha Urbana de São Paulo em 1890 com divisão distrital atual 
No final do século XIX a cidade de são Paulo estava em pleno processo de expansão territorial, os limites de bairros que já estavam estabelecidos foram ampliados e novos loteamentos surgiam. Principalmente nas porções sul e leste da cidade como Ypiranga [sic], Vila Prudente, Saúde, 4ª Parada e Vila Gomes Cardim. As linhas de bondes com tração animal serviam o centro da cidade e conectavam os bairros centrais as estações de trem.

Segundo (BRUNO, 1984) as linhas de bondes tracionadas por burros seguiam do Largo do Carmo em direção a Luz, do pátio do colégio ${ }^{54}$ para: o Brás (estação do Norte), Mooca, Campos Elíseos, Santa Cecília, Consolação e para Liberdade de onde partia um tramway para Vila Mariana e Santo Amaro.

Em 1889 criaram as linhas partindo da Sé para o Ipiranga e para Penha e ainda no mesmo ano foram implantados ramais para as Perdizes e para o Cemitério. (BRUNO, 1984)

No mapa 23, e 24 apresentados a seguir mostram a cidade de São Paulo representada de forma expandida com cerca de dez novos loteamentos, que darão origem a futuros bairros da cidade, a base do mapa de 1897 e representa a cidade na sua totalidade incluindo bairros mais distantes como Freguesia do Ó, Penha, Pinheiros, Vila Mariana servida por um tramway vindo da Liberdade.

Além da mancha urbana de mostrada com uma divisão por bairros nos mapas $23 \mathrm{e}$ 24, a seguir foram inseridas também as estações de trem que aparecem no mapa base original assim como as linhas de tramway da Cantareira, da Liberdade até o Matadouro Municipal localizado na Vila Mariana e o ramal da linha férrea Central do Brasil que levava a Penha.

Outro fator relevante nesse período de expansão urbana da capital paulista foi o fluxo de imigrantes na cidade segundo (MORSE, 1970) a porcentagem da população estrangeira na cidade passou de 8\% em 1872 para 25\% em 1886.

No final do século XIX surgiram, e em alguns casos como Brás e Luz ampliaram se, os bairros que serviam de moradia aos operários das fábricas que estavam instaladas em São Paulo nas proximidades das linhas férreas. Os bairros operários desse período são: no sul o Ipiranga, Cambuci, no centro a Mooca, Brás, Luz e Bom Retiro e no oeste Barra Funda, Água Branca, e Lapa são exemplos de bairros operário

\footnotetext{
${ }^{54}$ Onde encontrava se a primeira estação de bondes da cidade chamada de Califórnia. (BRUNO, 1984)
} 


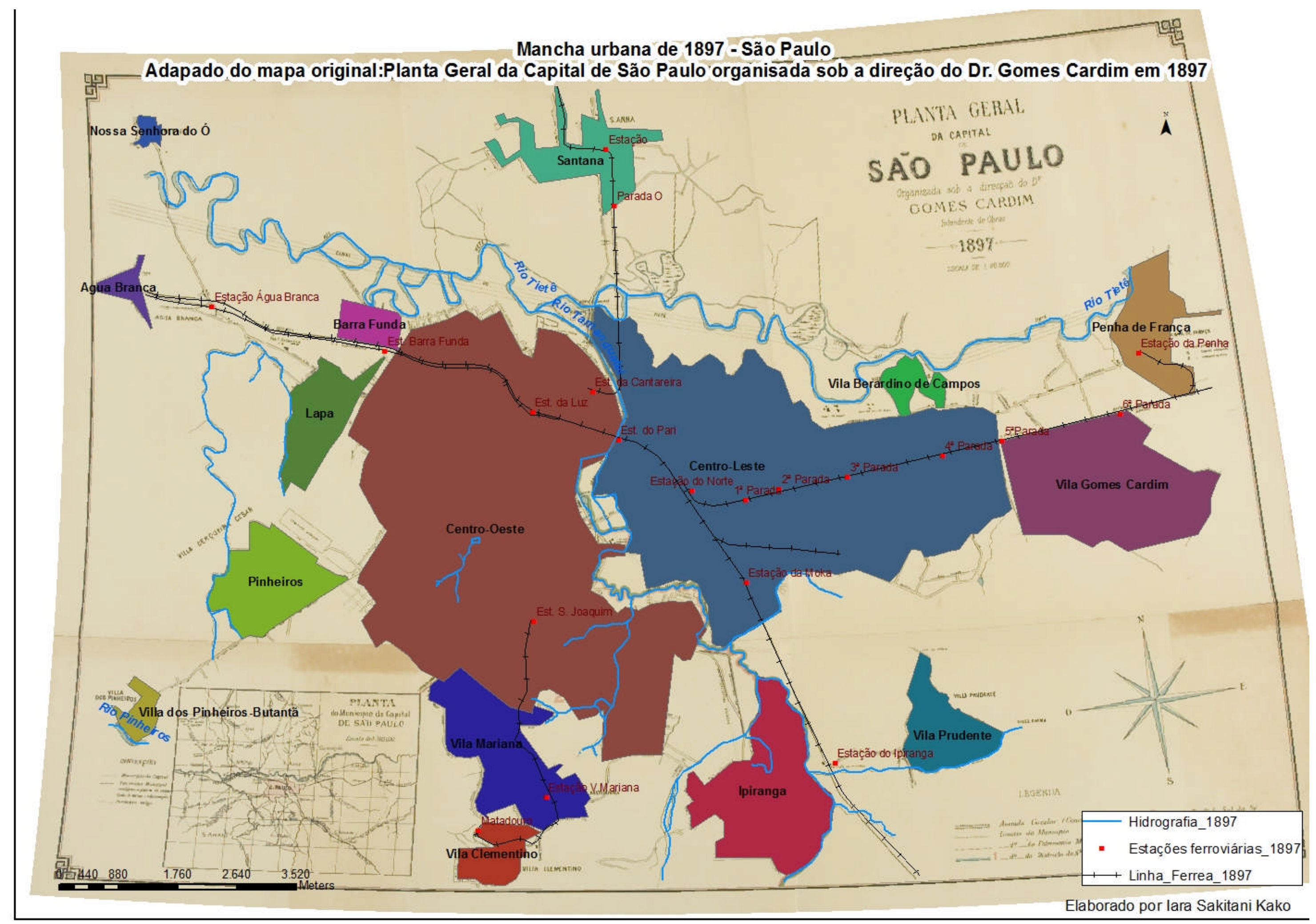

Mapa 23 Mancha Urbana de São Paulo em 1897 sobre mapa original 


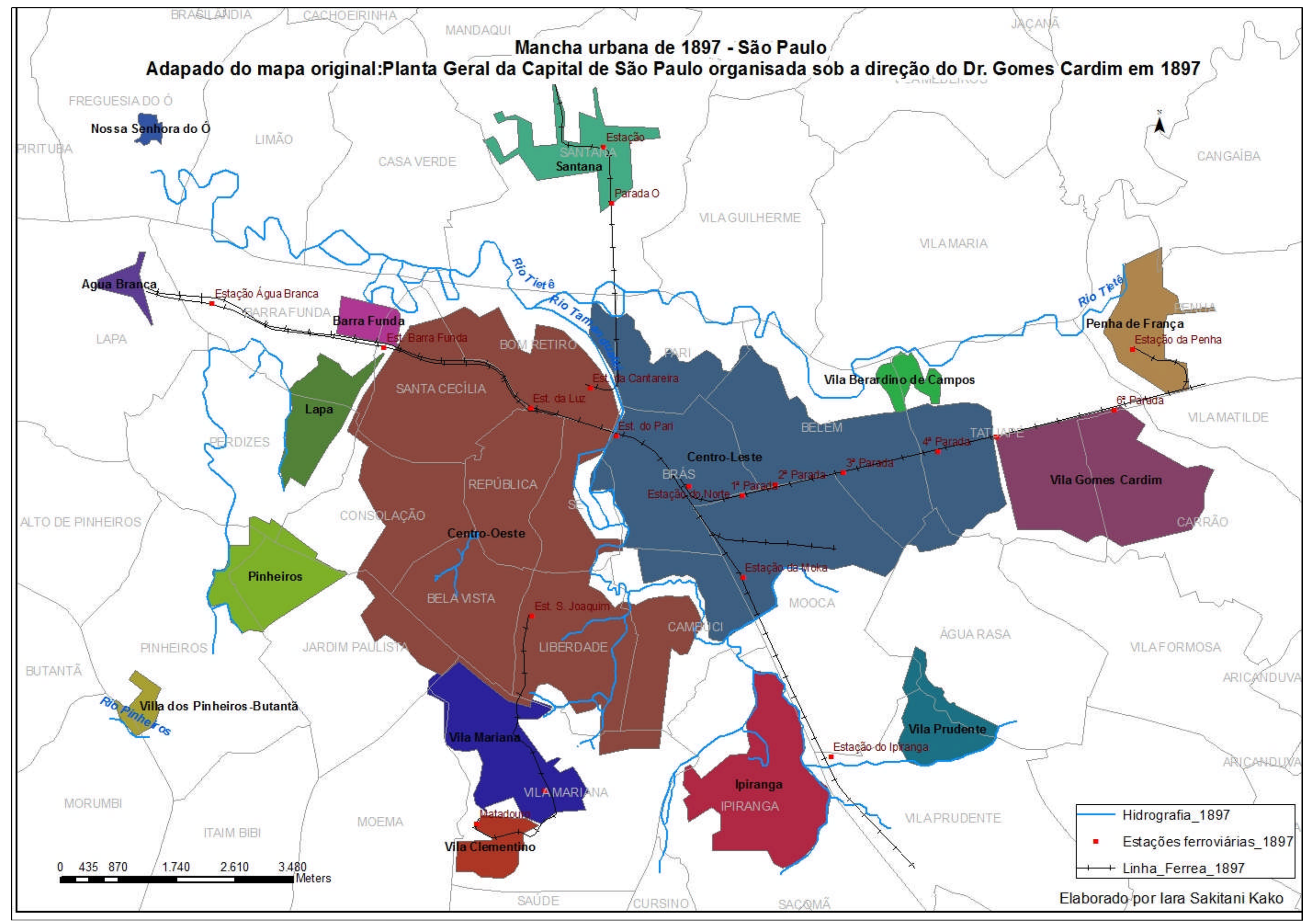

Mapa 24_Mancha urbana de São Paulo em 1897 com divisão distrital atual 
No início do século XX a cidade de são Paulo possuía $239.820^{55}$ habitantes e isso significava um crescimento de 369\% em dez anos.

Com a chegada do serviço de eletricidade os bondes a tração animal foram substituídos por bondes elétricos a partir de 1900 e em no final de 1901 a extensão das linhas de bondes era de aproximadamente $80 \mathrm{Km}$, servindo vários bairros da cidade e inclusive chegando até a Penha, Barra Funda, Paulista, Bom Retiro e a outros bairros listados na página 24 .

Nota se que a cidade está com seus limites ampliados para além do triângulo central de origem. Ao longo da linha férrea no eixo leste-oeste há uma continuidade entre os bairros. Os bairros da Lapa, Perdizes e Consolação estão interligados assim como Brás, Belém e Moóca em direção ao Tatuapé e Penha.

Algumas fábricas existentes em 1905 estão representadas no mapa original e foram destacadas no mapa 24 todas elas estão localizadas nas proximidades das linhas férreas.

Apenas três bairros representados no mapa não estão interligados com a mancha urbana contínua, são eles: Pinheiros, Freguesia do Ó e Vila Prudente. O bairro do Ipiranga não aparece ligado à mancha urbana central, porém possui uma linha de bonde que faz essa ligação com o centro da cidade.

Nota se que em 1905 havia bairros como Lapa, Barra Funda, Luz, Brás, Belenzinho, Moóca, Penha, Vila Mariana, Vila Clementino e Ipiranga que são servidos tanto pela linha de bonde como pela linha férrea. Enquanto bairros como Pinheiros, Villa [sic] Cerqueira César, Vila Prudente e Nossa Sra. Do Ó que não eram servidos por trilhos em sua área de influência.

Os três mapas apresentados a seguir mostram o resultado da sobreposição de layers. Ação que permite a visualização dos dados espaciais para um fim específico, como no mapa 25 que é resultado da combinação de seis layers ou camadas as quais foram compostas com a finalidade de mostrar a relação entre a mancha urbana, os trilhos e as fábricas. A relação entre os trilhos e a mancha urbana pode ser observada com facilidade no mapa, pois os trilhos estão em quase toda a superfície da mancha urbana com poucas exceções como Vila Prudente, Pinheiros e Freguesia do Ó.

\footnotetext{
${ }^{55}$ Dado referente ao ano de 1900 extraído do site do IBGE http://www.ibge.gov.br/seculoxx/arquivos xls/populacao.shtm
} 
Mancha urbana e linhas de bondes 1905 - São Paulo

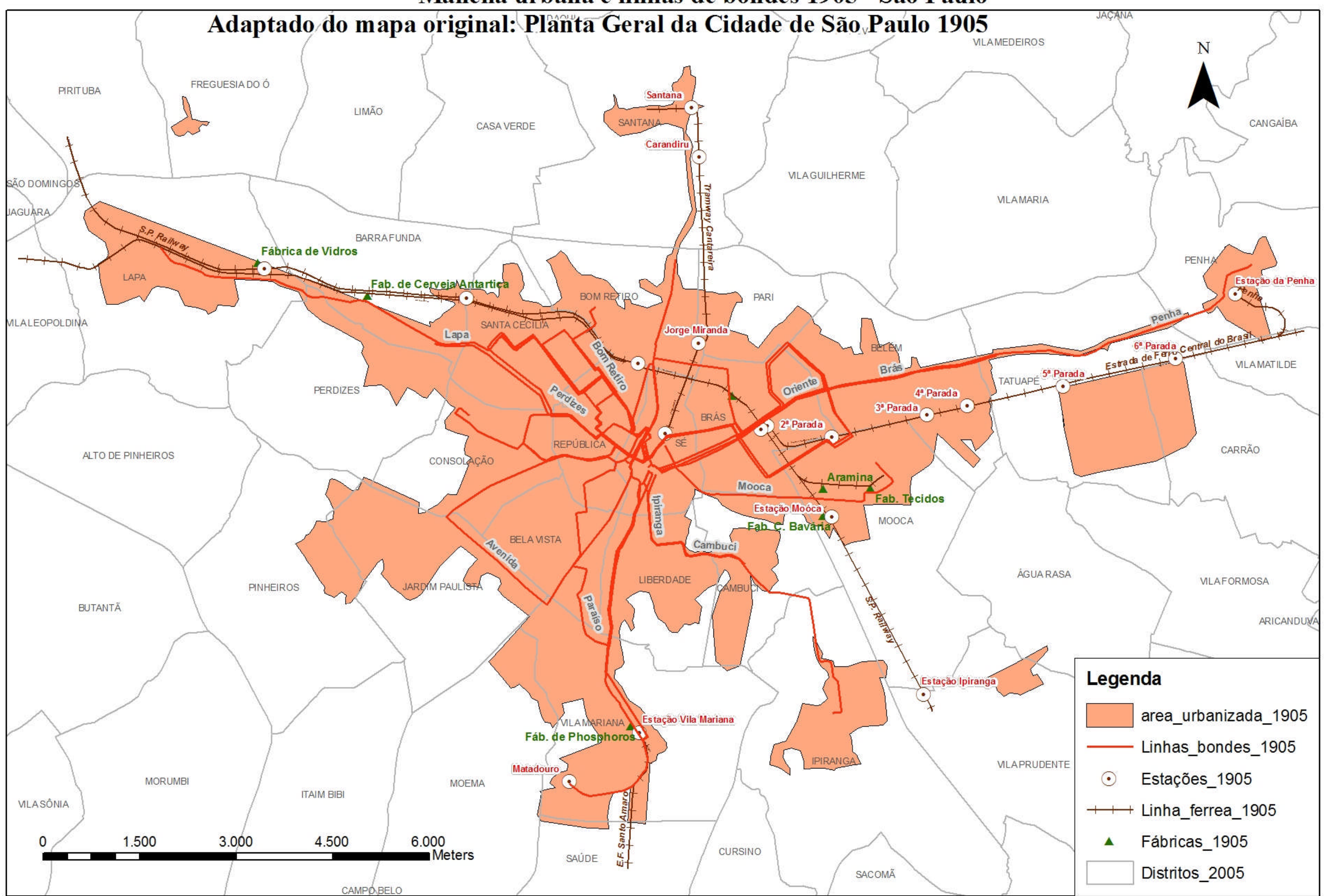

Mapa 25_Mancha urbana, linhas de bondes e fábricas em São Paulo no ano de 1905 
A expansão territorial da cidade entre o final do século XIX e o ínicio do século $X X$ foi grande, em 1905 a área urbana era igual a $44,86 \mathrm{Km}^{2}$ e os novos loteamentos (projetados) somavam 5,79 km² num total de 50,65 km². Se comparado com o mapa anterior de 1897 parece ter havido um decréscimo de $11 \%$ da área urbanizada. $E$ isso ocorre por conta dos novos loteamentos que no mapa de 1897 somavam 15,82 $\mathrm{km}^{2}$ sendo a área urbanizada igual a 40,84 km². Se contabilizada apenas a área urbanizada de 1897 sem os loteamentos novos e em relação à área urbanizada de 1905 constata se um aumento de $10 \%$ da mancha urbana, ou seja, a área de 40,84 km² em 1897 passa para 44,86 km² em 1905.

Nos mapas 26 e 27 apresentados a seguir estão traçadas as linhas de bondes que circulavam em 1905 que é a data da elaboração do mapa e a mancha urbana respectivamente.

No mapa 26 há uma tabela mostrando as informações das linhas de bondes traçadas sobre o mapa: o número da linha (Id), nome da linha, data de inauguração da linha (Start date) e seu comprimento em quilômetros. A tabela mostrada faz parte do banco de dados utilizado na elaboração do mapa.

O mapa 27 mostra um exemplo do uso dos polígonos de Thiessen para definir a área de influência de cada bairro que foi traçado no mapa como polígono. Através da análise das áreas dos polígonos construídos ao redor do centróide dos bairros é possível notar quais os bairros eram mais bem servidos de transporte por bondes e quais não possuíam acesso ao serviço como, por exemplo, o bairro de Nossa Senhora Do Ó que aparece isolado da mancha urbana central, assim como o bairro de Pinheiros. 
Mancha urbana e linhas de bondes 1905 - São Paulo

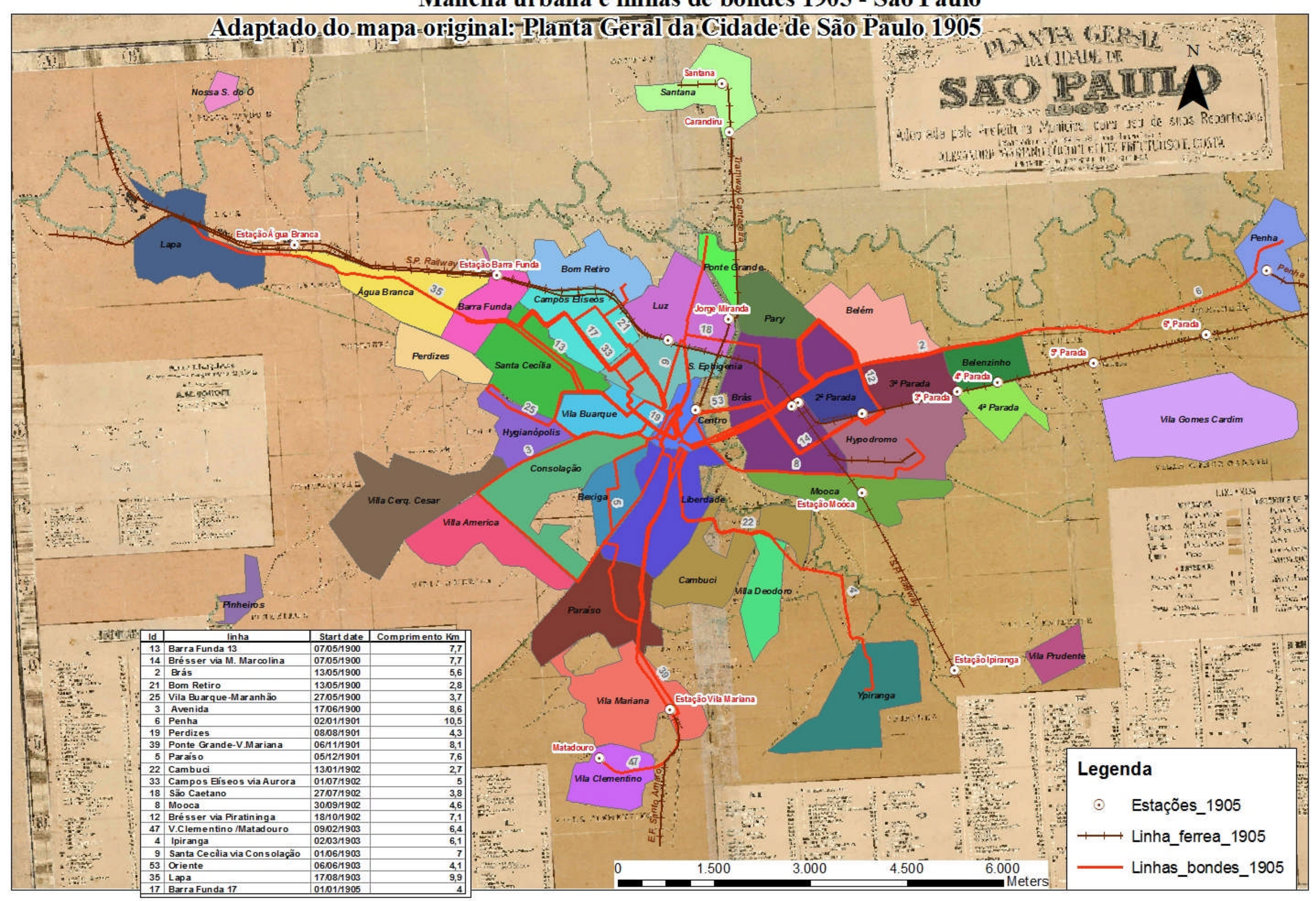

Mapa 26_Bairros e linhas de bondes em São Paulo - 1905 
Áreas de influência dos bairros 1905 - São Paulo

Adaptado do mapa original: Planta Geral da Cidade de São Paulo 1905

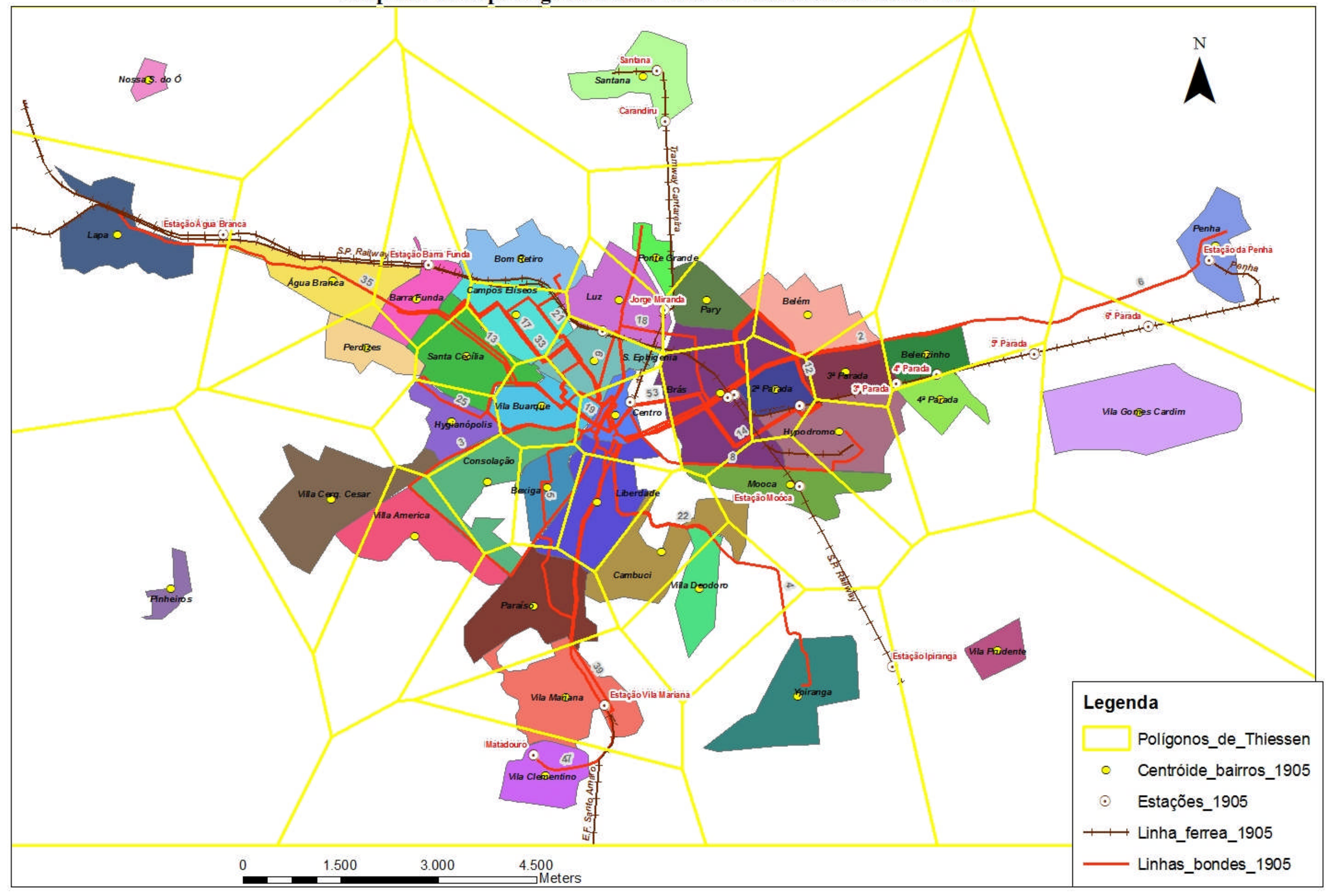

Elaborado por lara Saktani kako

Mapa 27_Uso de Polígonos de Thiessen para representar área de influência por bairro em 1905 - São Paulo 
Nas primeiras décadas do século XX a cidade de São Paulo cresceu extraordinariamente passando de 239.820 habitantes em 1900 para 579.033 em 1920. O gráfico 1 a seguir mostra a curva de crescimento populacional da cidade de São Paulo no período de 1872 à 1920.

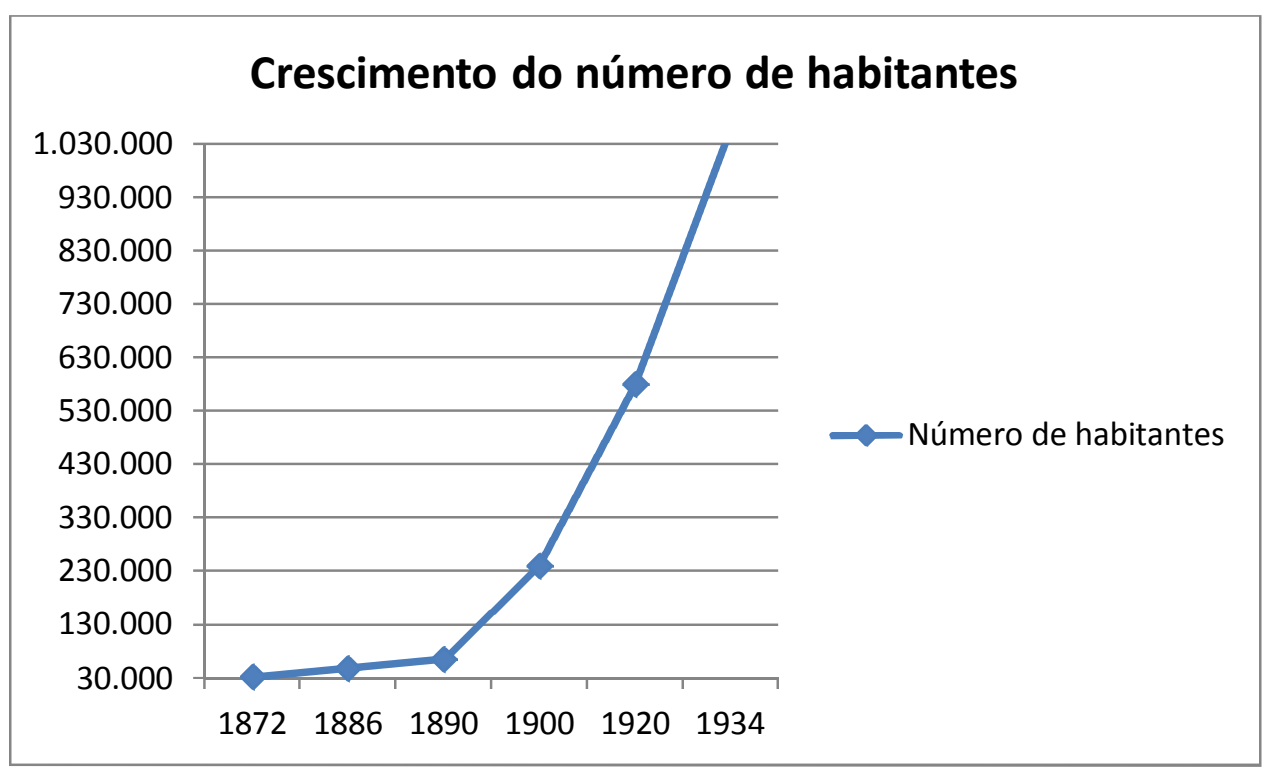

FONTE - Annuario estatistico do Brazil 1908-1912. Rio de Janeiro: Directoria Geral de Estatistica, v. 1-3, 1916-1927 FONTE - http://www.ibge.gov.br/seculoxx/arquivos_xls/populacao.shtm Gráfico 1_Crescimento Populacional 1872-1934 - São Paulo

O mapa de 1914 foi utilizado como base para elaboração do mapa 28 mostrado a seguir, área urbanizada de 1914 era igual a $65,82 \mathrm{~km}^{2}$, ou seja, $30 \%$ maior em relação à área urbanizada de 1905 . A cidade cresceu principalmente nos vetores sul e oeste, como mostra o mapa 28 através dos novos loteamentos e da expansão da Vila Mariana e Aclimação, criação do loteamento - pela Cia City- do Jardim América ou Villa [sic] América, expansão do bairro de Pinheiros em direção a Cerqueira César e criação da Vila Leopoldina. O Pacaembu que até então provavelmente por sua topografia não havia sido loteado.

As linhas de bondes de 1905 e 1914 quando comparadas em um raio de 3 e 5 quilômetros a partir do centro nos mapas 29 e 30 mostram que há um aumento da quantidade de linhas que servem ao centro no raio descrito. Pode se notar também o aumento da mancha urbana inscrita nos raios (buffers) traçados, principalmente na parte oeste e sudoeste da cidade. 


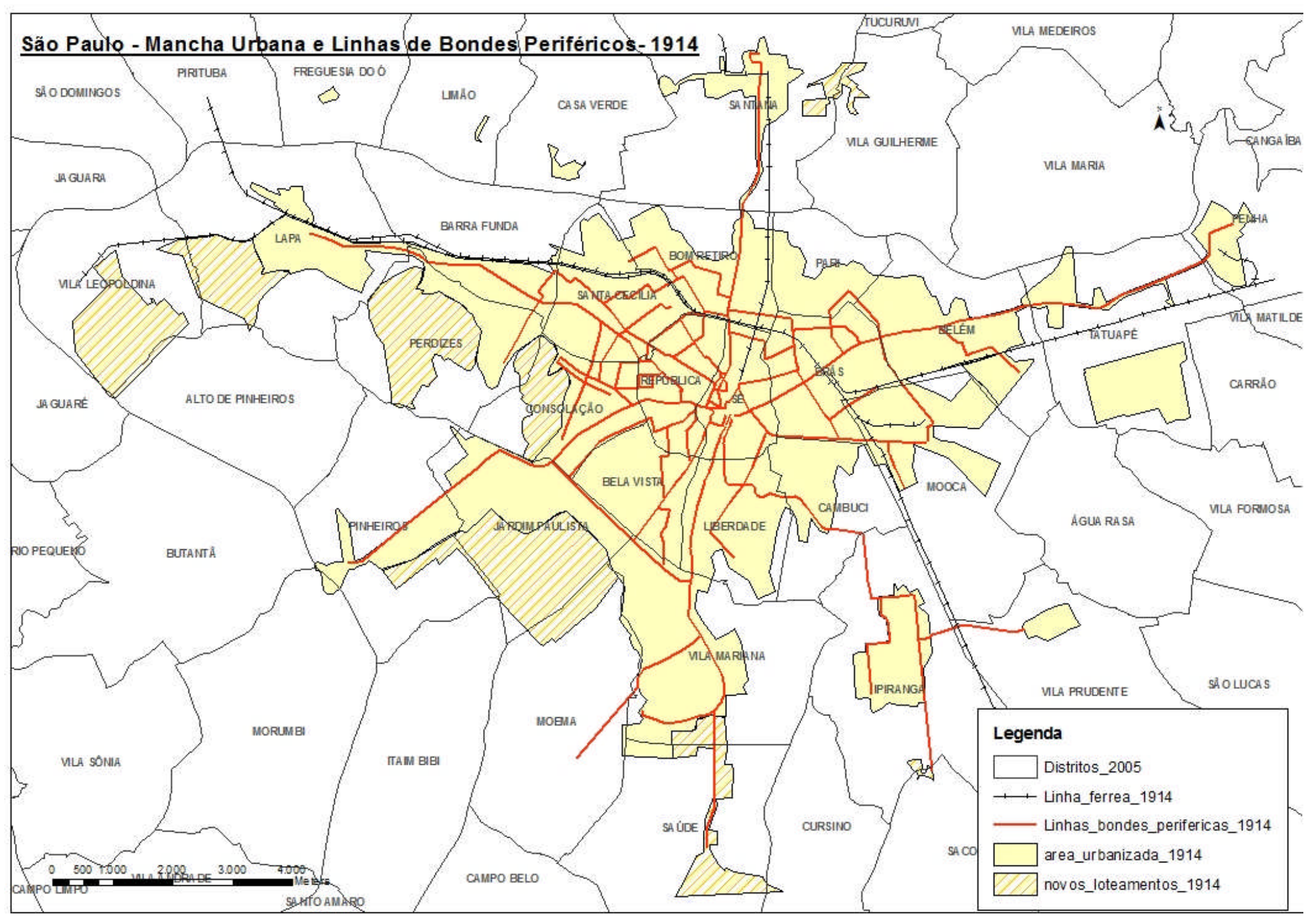

Mapa 28_Mancha urbana e linhas de bondes de São Paulo - 1914 


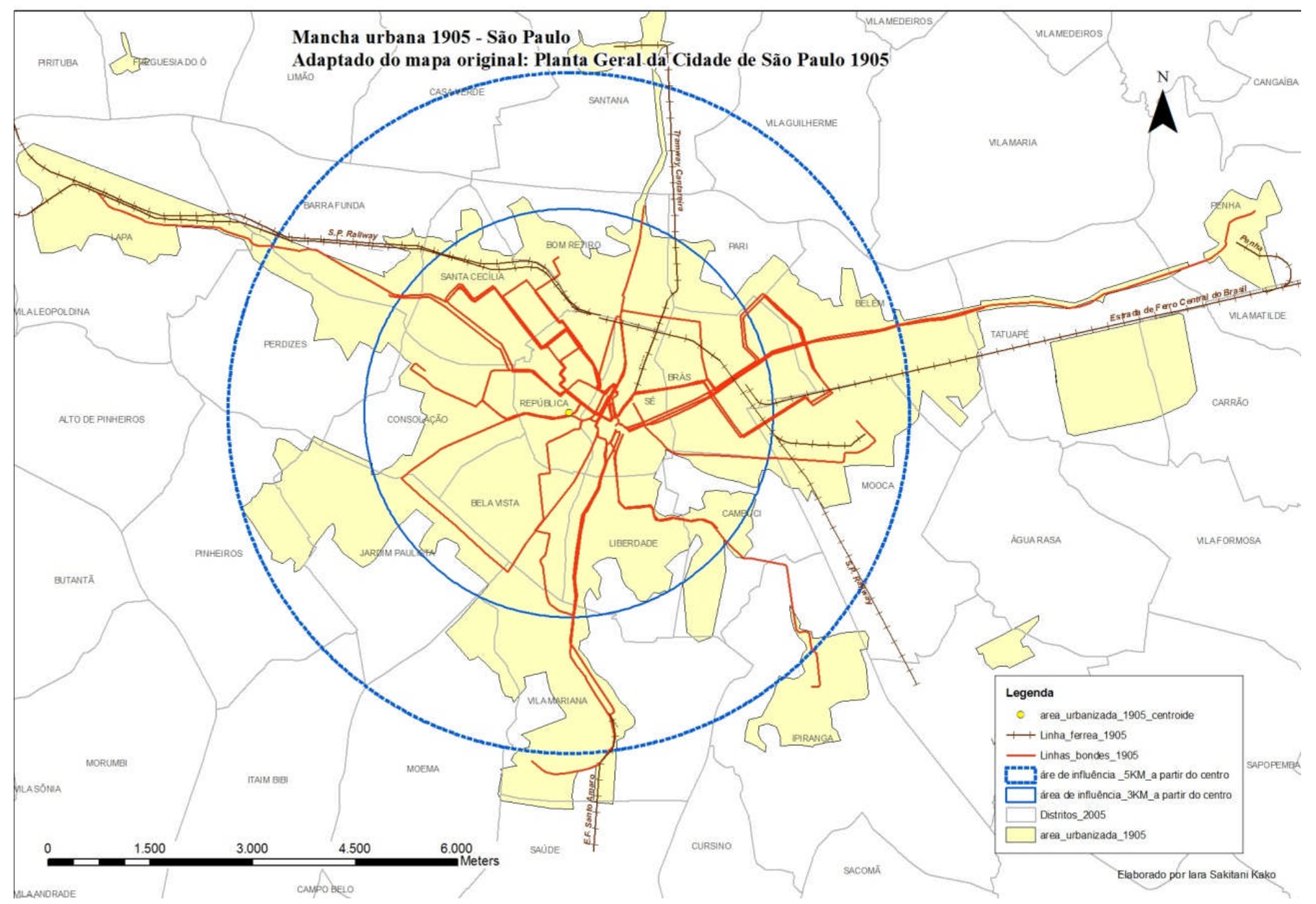

Mapa 29_Linhas de bondes - São Paulo área central - 1905 


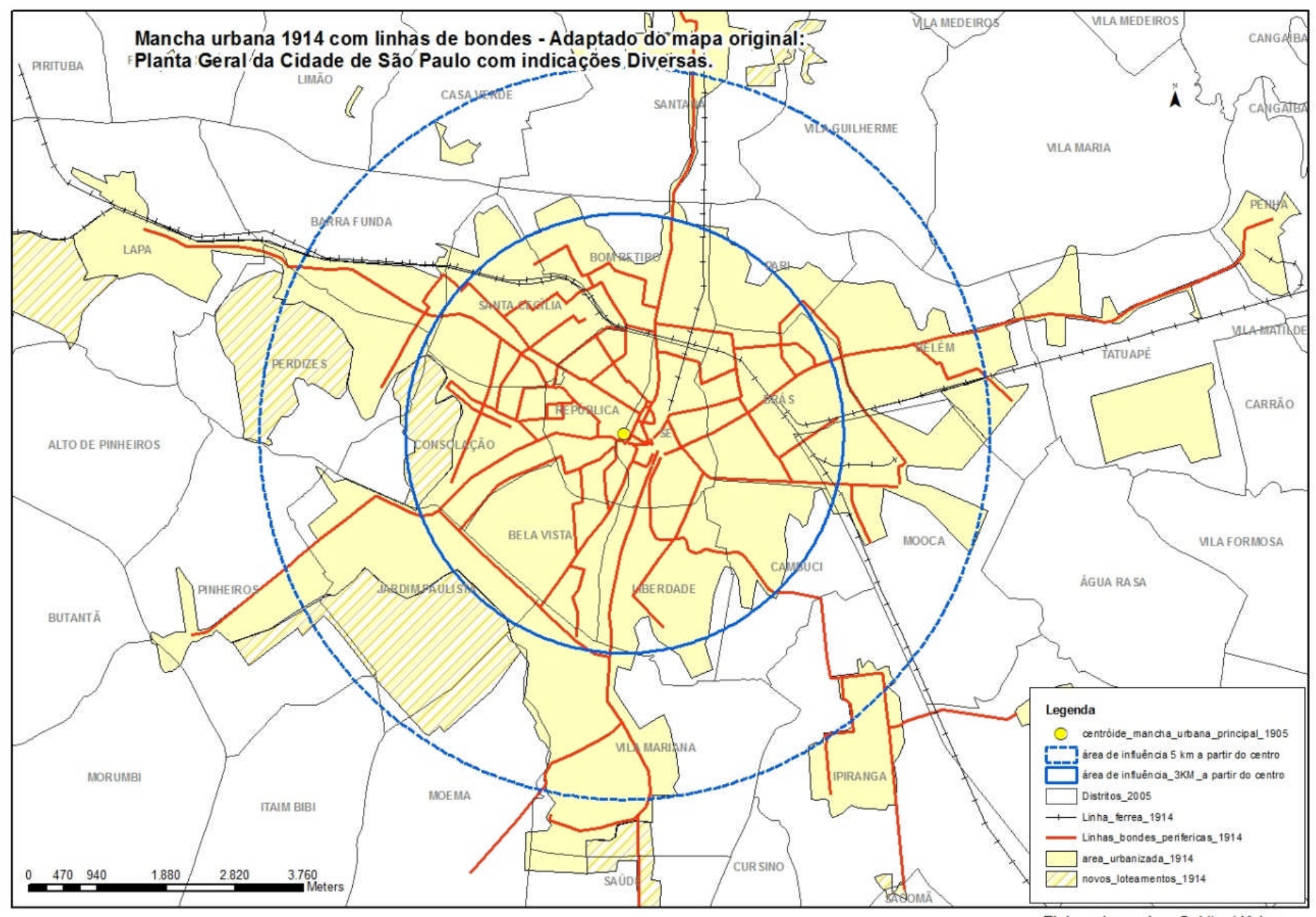

Mapa 30 _Linhas de bondes - São Paulo área central - 1914 
Durante a década de 20 a cidade de São Paulo tem seus limites de área urbanizada muito ampliados principalmente no eixo norte-sul, e é possível notar esse fenômeno observando o mapa 31 mostrado a seguir. Em 1924 vários bairros como: Vila Guilherme, Tucuruvi, Vila Medeiros e Jaçanã formam se ao longo da linha férrea para Guapira. Observa se também o prolongamento da linha do tramway da Cantareira até o Mandaqui.

No vetor sul a mancha urbana expande se em direção ao então município de Santo Amaro, bairros como Indianópolis e Campo Belo começam a conectar se formando um tecido urbano único que virá a concretizar se nos anos seguintes com a anexação do município de Santo Amaro à capital.

O mapa 32 apresentado a seguir mostra dois círculos concêntricos, elaborados com a ferramenta buffer, com raio de três e cinco quilômetros respectivamente, onde destacam se a área urbanizada da cidade, as linhas de bondes e férreas pelas quais circulava se em São Paulo. O mapa 32 mostra uma densa rede de linhas de bondes na primeira área chamada de influência do centro. Se comparada com o mapa anterior de 1914 (mapa 30 acima) percebe se uma ampliação da rede de trilhos de bondes, e que houve um prolongamento dos trilhos para atingir os bairros da Casa Verde, Sacomã, Indianópolis, Pari, assim como para a Lapa e foram inseridos dois ramais na linha da Bela Vista para atender ao Jardim Paulista.

Assim a mancha urbana e os trilhos foram caminhando quase que conjuntamente.

Em 1924 São Paulo possuía aproximadamente 56 linhas de bondes que ramificavam do centro para todas as direções da cidade.

Os mapas 31 e 32 mostrados a seguir são o retrato da cidade com seus trilhos e também é possível identificar pequenos núcleos de bairros que formam se ao norte, ao oeste e ao leste do centro expandido. Ao sul a formação dos bairros já parece ocorrer através de grandes loteamentos que muitas vezes seguem com as suas ruas paralelas aos trilhos como no caso do bairro de Indianópolis situado entre os distritos atuais de Moema e Campo Belo. 


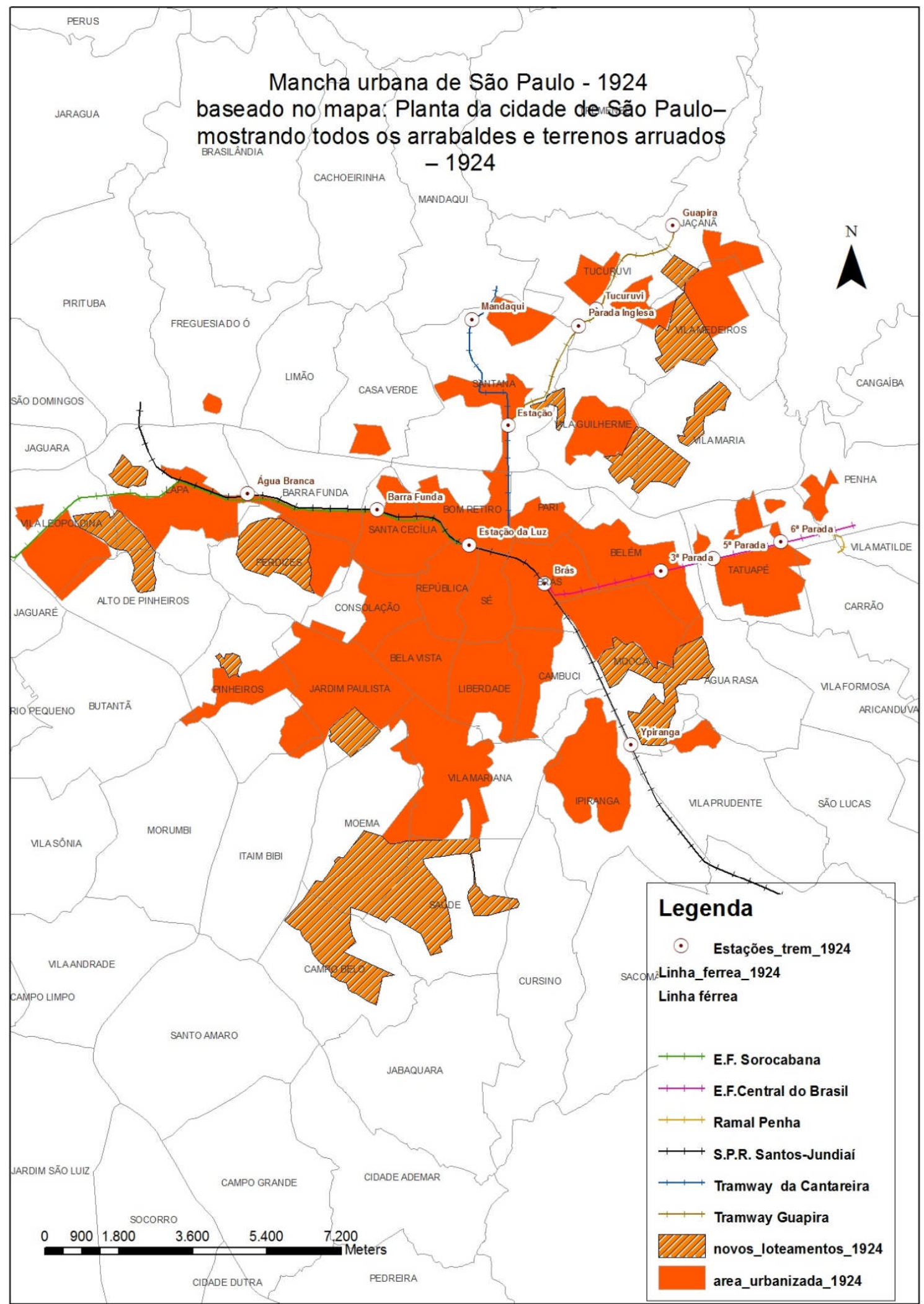

Elaborado por lara Sakitani Kako

Mapa 31_Mancha urbana de 1924 - São Paulo 


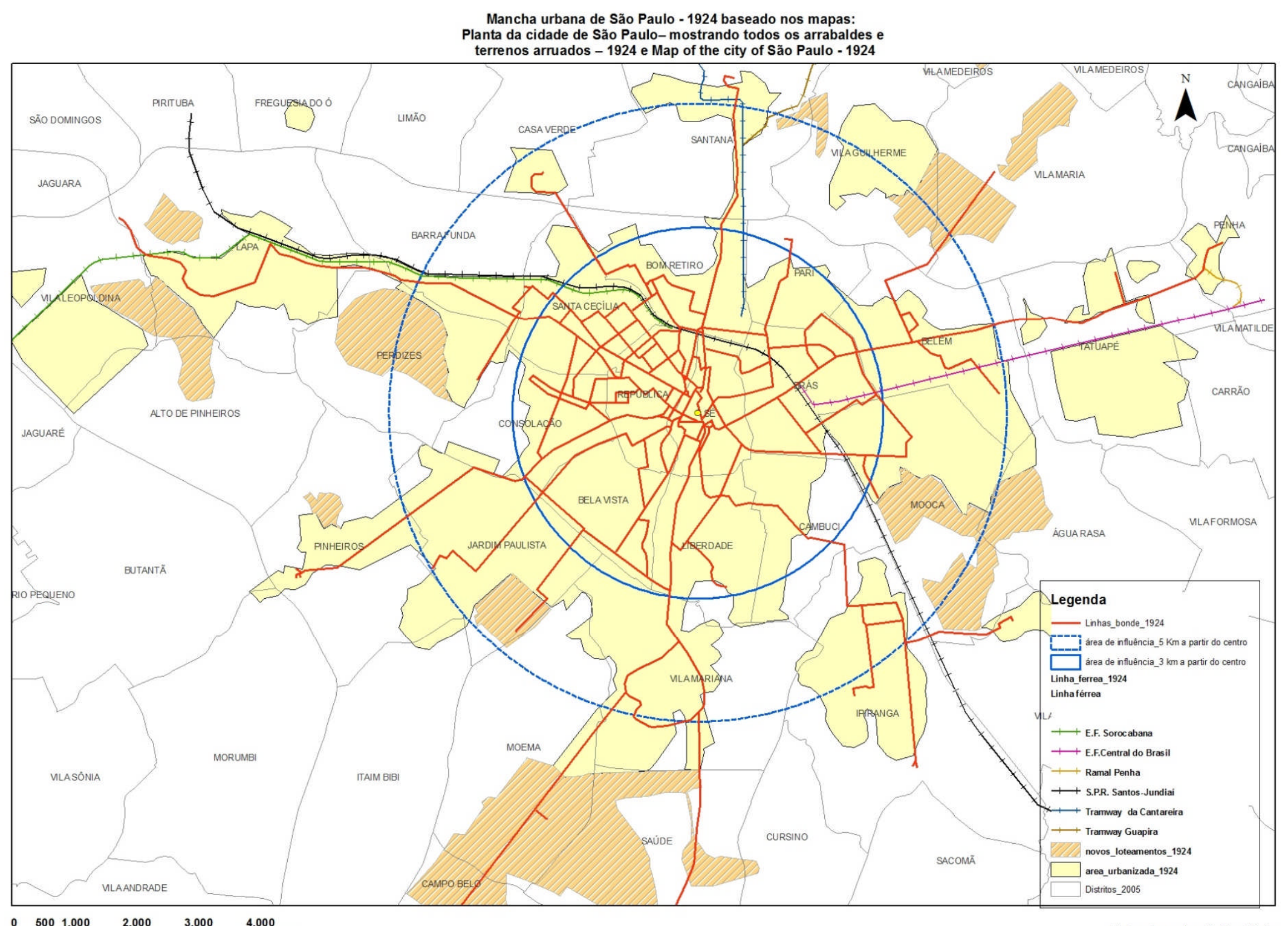

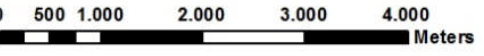

Elaborado por lara Sakitani Kako

Mapa 32_Linhas de Bondes - São Paulo - 1924 
Como crescimento da mancha urbana no período selecionado para este estudo foi bastante extenso para finalizar os resultados obtidos em mapas foram elaborados os mapas 33 e 34 a seguir onde através da sobreposição das camadas contendo o desenho da mancha urbana nas diferentes datas obteve se dois mapas que congregam as informações extraídas dos diferentes mapas.

Para uma melhor visualização da informação a representação do crescimento da mancha urbana foi dividida em dois períodos.

O primeiro período apresentado no mapa 33 que corresponde de 1847 até 1890, mostra o tímido crescimento da mancha urbana que fica restrito á área central da cidade com um pequeno prolongamento até o Brás em 1881, e um maior aumento da área em 1890 englobando as margens das linhas férreas.

O segundo período apresentado no mapa 34 que corresponde de 1890 até 1927. Este inclui o mapa de 1897 com seus limites ampliados. Ao sobrepor os diversos mapas o resultado visual mostra uma cidade que dobra de tamanho no século $X X$ com seus múltiplos núcleos de bairros descontínuos a mancha central. Durante o processo de sobreposição das camadas os espaços " em branco" no mapa vão aos poucos deixando de existir e o resultado aparece em um mapa com a área central como previsto por Gomes Cardim em 1897 totalmente interligada, sem "vazios".

Bairros como o Ipiranga, Pinheiros, Lapa e Vila Mariana que no século XIX estavam distantes do centro pela falta de uma ligação com eles ou pelo tempo que se levava para chegar a eles na década de 20 já estão conectados pela mancha urbana e pelo transporte de trilhos.

A sobreposição de mapas é uma técnica de estudo muito utilizada pelos geógrafos. Quando não havia o auxílio da cartografia digital e dos Sistemas de Informações geográficas a técnica consistia em generalizar os mapas para uma mesma escala e copiá-los sobre folhas de papel vegetal para assim iniciar a sobreposição.

Atualmente com os Sistemas de Informações Geográficas essas operações ocorrem com maior agilidade permitindo que a escala, projeções, camadas e cores sejam mudadas rapidamente.

Porém como o trabalho foi feito com mapas históricos o ajuste de sobreposição ainda não ficou perfeito, mesmo com o georefenciamento dos mapas feito na mesma base cartográfica. 


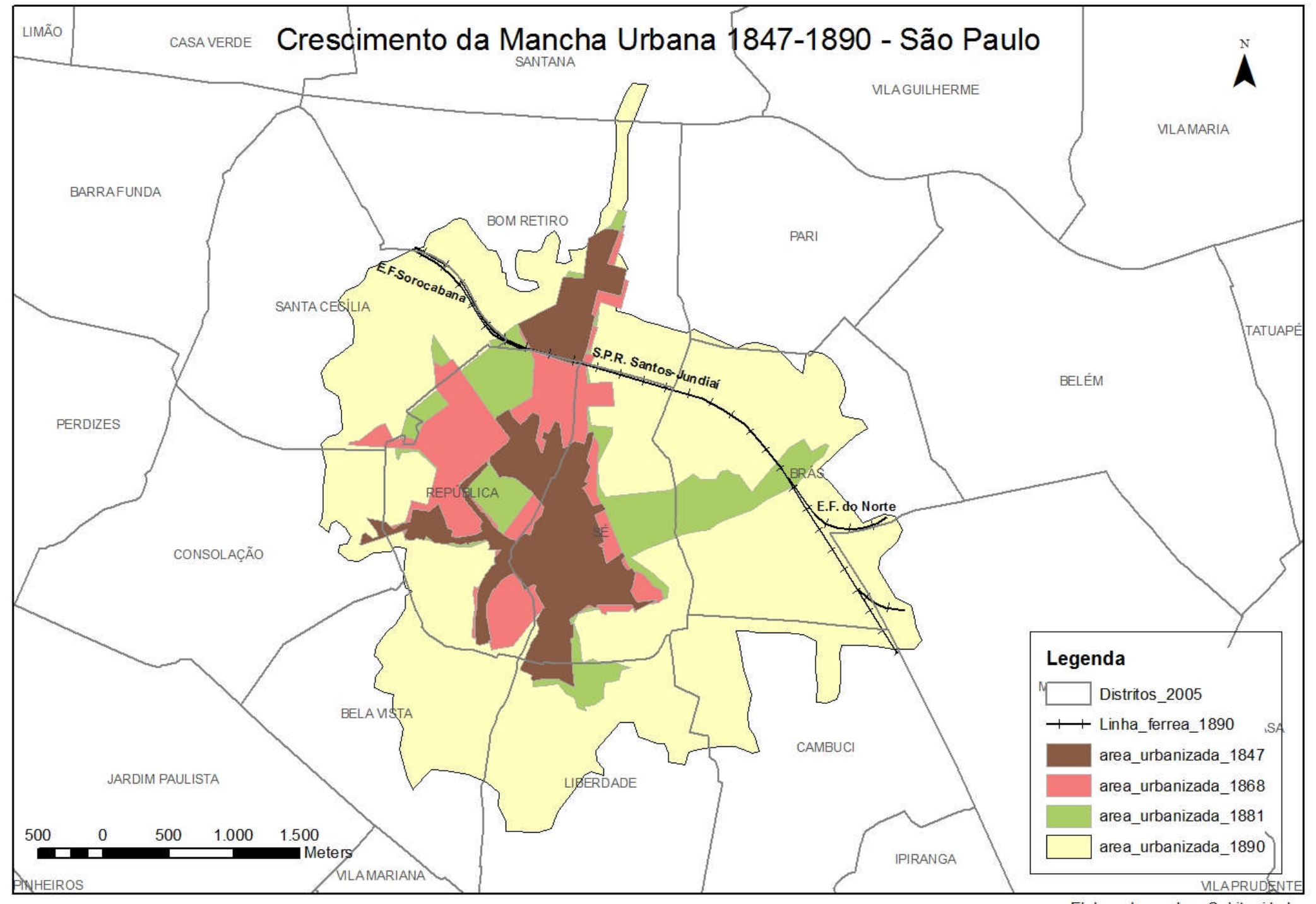

Elaborado por lara Sakitani kako

Mapa 33_Crescimento da Mancha urbana de São Paulo - 1847-1890 


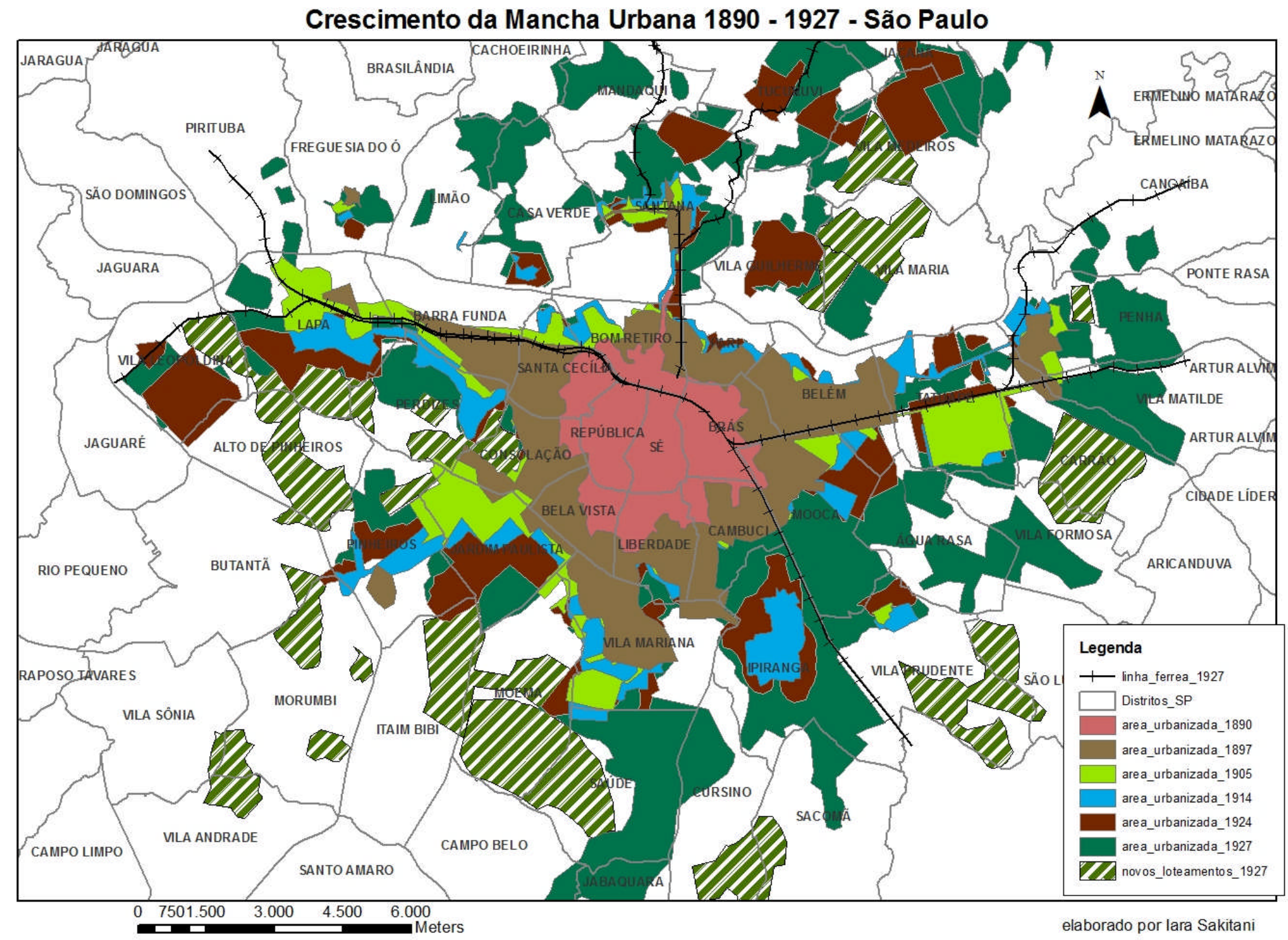

Mapa 34_Crescimento da Mancha Urbana 1890-1927 - São Paulo 


\section{Conclusões e trabalhos futuros}

Este capítulo apresenta as considerações finais da pesquisa e sugestões para estudos futuros.

\section{1 Conclusões e verificação da hipótese}

O objetivo geral desta pesquisa foi avaliar a influência dos trilhos no processo de urbanização da cidade de São Paulo no período de 1870 a 1930, utilizando como instrumento de análise auxiliar dos estudos geográficos a cartografia digital aplicada a mapas históricos criados nesse período. Buscou-se produzir mapas temáticos a partir de uma seleção de mapas históricos da cidade e neles identificar os seguintes elementos: mancha urbana, bairros existentes, loteamentos planejados, traçado de caminhos, ferrovia, tramway e bondes.

A produção dos mapas correspondeu às expectativas constantes no início do trabalho. Ao analisar os resultados apresentados no capítulo 8 , juntamente com as considerações a respeito dos mapas citados no capítulo 7 , foi possível concluir que o crescimento da cidade de São Paulo, observado através da expansão da sua mancha urbana, deveu-se a um conjunto de fatores incluindo neles o crescimento da economia cafeeira, a implantação da ferrovia, a instalação de capital financeiro através dos bancos e o grande fluxo de imigrantes a partir do final do século XIX. Tendo-se relacionado a imigração ao crescimento populacional e à criação de fábricas nas margens da ferrovia. Esses são fatores que estão interligados ao desenvolvimento vertiginoso da cidade e ao consequente aumento da demanda por infraestrutura de água, energia, transporte, moradia e saneamento, a qual cresce conjugada ao crescimento populacional.

São Paulo, como mostrado no mapa 1 , teve sua posição geográfica favorecida por estar no entroncamento de caminhos utilizados pelas tropas para escoamento de mercadorias, seja para o litoral, seja para o interior. ficou marcado o seu papel, não só de capital e centro de decisões, de nó de comunicações e caminho necessário para o porto de Santos. Essa posição favorecida da cidade, como nó de 
comunicação, beneficiou a implantação da primeira linha férrea na cidade em 1867 e posteriormente o entroncamento de outras linhas. Fato que gerou uma série de implicações como a instalação de armazéns e fábricas (facilidade de transportes), a ocupação das várzeas seguindo o traçado da ferrovia, o surgimento de bairros a partir das estações ferroviárias como, por exemplo, o Brás e as demais paradas das ferrovias e o loteamento das chácaras próximas às linhas férreas, como apresentado nos mapas17 e 18, de 1868, e nos mapas 19 e 20, de 1881.

A demanda por infraestrutura (energia, água, saneamento, transporte e moradia) foi sendo suprida, de uma forma ou de outra, pelo poder público, aliado às companhias privadas, como a Cia. Cantareira de Águas e Esgotos (mapa 6), a Light and Power Co. (mapas 10, 13 e 14), a Cia. Carris, e algumas outras. Desse modoas companhias privadas tornaram-se responsáveis não apenas por suprir as demandas negociadas com o governo local, mas também por planejar o crescimento dessas, aumentando os seus ganhos de capitais. Dos mapas apresentados, alguns, conforme explicado no item 7.2, são resultado do planejamento dessa demanda de serviços, (por exemplo, os mapas 6, 10, 12 e 13).

Através da análise sequencial dos mapas, pôde-se observar que a demanda por transporte impulsionou a primeira das infraestruturas implantadas na cidade através da ferrovia que ligava Santos a Jundiaí, passando por São Paulo. Sendo ela fundamentalmente utilizada para o transporte de cargas atendia também ao transporte de passageiros. de tal modo que em pouco tempo as estradas entraram em decadência. Seqüencialmente neste processo está o atendimento da demanda de transporte de passageiros e assim foram estabelecidos os bondes à tração animal que serviam o centro da cidade no final do século XIX, seguidos pela construção das primeiras adutoras para fornecimento de água. Mais tarde, a partir de 1900 os bondes passam a ter tração elétrica e a instalação de energia irá atender a demanda residencial, comercial e principalmente industrial.

Verificou-se uma forte interação entre o serviço de bondes e a ferrovia, pois inicialmente a função dos bondes era a de ligar os bairros centrais às estações ferroviárias da Luz, do Norte e do Brás. A ferrovia situava-se fora ou na periferia da cidade.

Assim como os bondes e a ferrovia, os tramways também exerceram seu papel de conectores entre os bairros. Esse processo de anexação pode ser visualizado nos 
mapas 25, 26 e 28, onde os bairros Santana e Vila Clementino, primeiramente, aparecem isolados na mancha central da cidade e, posteriormente, conectam-se através do tramways e dos bondes o que provoca a ocupação das regiões intermediárias..

.A cidade cresceu de forma descontínua, como observado nos mapas 29 e 30, essa forma de crescimento dificulta o planejamento das demandas por transporte, energia, água e infraestrutura em geral. Mas isso deve estar relacionado com dois fatores principais: o valor dos terrenos e a sua acessibilidade: locais muito próximos do centro, além da resistência dos donos das chácaras, têm valores de terreno inacessíveis para moradia popular; locais muito longe dos meios de transporte não convidam à ocupação. Assim, a existência da ferrovia, dos tramways e dos bondes propiciaram a implantação de novos loteamentos nas zonas periféricas da cidade no período estudado. Os demais elementos de infraestrutura urbana ou não existiam em nenhum ponto da cidade ou eram bastante restritos, coisa que torna o transporte coletivo o principal elemento de ponderação na definição da ocupação do território urbano. Porém, não é o único deles e se associa a outros, como por exemplo dificuldades relativas à má qualidade do terreno (várzeas, topografia). $\mathrm{O}$ bairro do Pacaembu como exemplo, teve sua ocupação tardia apesar de ter linhas de bondes nas proximidades e de estar adjacente aos bairros já ocupados; isso pode dever-se às condições do ribeirão das pacas que dá origem ao nome do bairro e à topografia acidentada. As reservas de terrenos para ocupação futura devido aos projetos como os da Cia. City também criaram uma descontinuidade na ocupação da cidade; o mapa 12 de 1924 mostra as extensões das linhas de bondes chegando aos novos loteamentos da cidade como Vila América, Alto da Lapa e Pacaembu.

Através dos mapas que apresentam o aumento das linhas de bondes conclui-se que, em alguns casos, como o bairro do Ipiranga, o bonde é implantado na primeira fase de criação do loteamento, e, em outros casos, como o da Vila Prudente, o loteamento criado permanece por alguns anos sem acesso à linha de bonde, que é implantada posteriormente à sua criação e ocupação, esses bairros estavam servidos ainda que em condições precárias pela ferrovia.

Retomando a hipótese colocada no início do trabalho de que os trilhos (bondes, tramways e trens) apresentaram-se como um dos principais elementos estruturantes da ocupação do espaço urbano, atuando em conjunto com a implantação dos 
sistemas de água, esgoto e energia elétrica, e como apontamos com preponderância. Verificamos através da análise cartográfica e bibliográfica que os trilhos, além de melhorar o escoamento de mercadorias, possibilitaram o transporte de passageiros, promovendo a formação, a ampliação e o acesso às terras, orientando o uso e o tipo de ocupação do solo, ação perceptível através da expansão da área urbana como um todo.

Sobre a metodologia proposta para o estudo dos mapas históricos comprovou-se de forma prática, que a Cartografia digital e os Sistemas de Informações Geográficas são mesmo instrumentos que facilitam e tornam mais ágil a manipulação dos dados como, por exemplo, na construção dos mapas temáticos diversos, a visualização ou impressão de mapas derivados ou compostos para fins de comparação como, por exemplo, os mapas 29 e 30, e finalmente no processo de sobreposição das informações contidas nos diferentes mapas históricos.

Apesar dos problemas de ajustes imperfeitos em alguns casos, devido à falta de precisão em alguns deles, entre os mapas, a Cartografia digital permitiu a sobreposição de mapas construídos em diferentes escalas e projeções como nos mapas 33 e 34 .

\subsection{Estudos Futuros}

O tema abordado permite ainda que outros estudos sejam realizados para um aprofundamento na compreensão da relação entre os meios de transporte e a expansão urbana. O uso do método de cálculo dos Polígonos de Thiessen e a construção de Buffers e Áreas de Influência permitirá criar índices de qualidade de transporte em estudos sobre a distância percorrida pela população ao acessar os equipamentos urbanos mais relevantes. Como ensaiado no mapa 27.onde o centróide de um bairro e a estação mais próxima (trem ou linha de bonde) permite calcular a distância média que a população tem que se deslocar; através de uma estimativa do número de habitantes (pelo censo confrontado com a área do bairro e a densidade populacional) permitem criar um índice parcial de avaliação da qualidade. 
Ainda do ponto de vista da cartografia, cabe tanto estudar outros mapas do período, como ampliar a seqüencial temporal e geográfica de estudo. Por outro lado, um trabalho interessante seria buscar e integrar outras fontes de dados como os dados populacionais por distritos e bairros da cidade em cada data; mais dados sobre a implantação dos bondes, bem como as estatísticas de passageiros transportados; explorar temas concretos como o tramway da Cantareira; correlacionar com a implantação de outras infraestruturas como o abastecimento de água e a energia elétrica. Tudo isso sem esquecer o grande tema do urbanismo e ocupação do território.

Em resumo trata-se de um tema interdisciplinar com muitas perspectivas de desenvolvimento. Espera-se ter dado um pequeno passo e uma contribuição para futuros desenvolvimentos. 


\section{REFERÊNCIAS}

AZEVEDO, A. (1958). A cidade de São Paulo: Estudos de Geografia Urbana. São Paulo: Cia Editora Nacional.

BARROSO, G. (1941). O Brasil na lenda e na cartografia antiga. São Paulo: Companhia editora nacional.

BERTIN, J. (1967). Semiologie Graphique: Lês Diagrammes - Les Réseaux - Les Cartes. Paris: Mouton.

BRUNO, E. d. (1954). História e Tradições da Cidade de São Paulo.VII. Rio De Janeiro: José Olympio.

BRUNO, E. d. (1984). História e Tradições da Cidade de São Paulo.VIII. (3ª ed.). São Paulo: HUCITEC.

BUENO, B. P. (2009). Do borrão às aguadas: os engenheiros militares e a representação da Capitania de São Paulo. Anais do Museu Paulista , 111-153.

BUENO, Eduardo (org.). (2004) Os nascimentos de São Paulo. Rio de Janeiro: Ediouro,.

BURROUGH, P. A. (1998) Principles of geographical information systems. Oxford New York : Oxford University Press, c1998, 1999, 2000.

CAMPOS, E. (2006). A vila de São Paulo do Campo e seus caminhos. Revista do Arquivo Municipal / Departamento do Patrimônio Histórico , 11-34.

CAMPOS, Eudes (2008). São Paulo antigo: plantas da cidade. INFORMATIVO ARQUIVO HISTÓRICO MUNICIPAL, 4 (20): set/out. http://www.arquivohistorico.sp.gov.br acesso em 10/06/2010.

CAVENAGHI, A. J. (2010). Nossa herança imperceptível: uma análise historiográfica da obra Collectanea de. $3^{\circ}$ Simpósio Iberoamericano de História da Cartografia , 1 15.

CINTRA, J. P. (1985). Modelagem digital de terrenos. São Paulo: Tese de Doutoramento, Universidade de São Paulo.

CINTRA, J. P. (2004). Plantas Históricas. In: I. IDOETA, São Paulo vista do Alto: 75 anos de aerofotogrametria (pp. 73-95). São Paulo: Érica.

CINTRA, J. P. (Abril de 2010). A Cartografia digital como ferramenta para a Cartografia histórica. 3o Simpósio Iberoamericano de História da Cartografia . 
COMISSÃO NACIONAL PARA AS COMEMORAÇÕES DOS DESCOBRIMENTOS PORTUGUESES. (1997). Cartografia e diplomacia no Brasil do século XVIII. Lisboa: Comissão Nacional para as Comemorações dos Descobrimentos Portugueses.

CORTESAO, A. (1935) Cartografia e cartografos portugueses dos seculos XV e XVI contribuicao para um estudo completo. Lisboa Seara Nova . VII

CORTESÃO, J. (1955). A Fundação de São Paulo, Capital Geográfica do Brasil. Rio de Janeiro: Livros de Portugal.

CORTESÃO, J. (1955). A Fundação de São Paulo, Capital Geográfica do Brasil. Rio de Janeiro: Livros de Portugal.

COSTA, G. (2007). Roteiro Prático de cartografia da América portuguesa ao Brasil Império. Belo Horizonte: UFMG.

DENÈGRE, J., \& SALGÉ, F. (2004). Les systèmes d'information géographique. Paris: PUF.

FERREIRA, N. C. (s.d.). Aquisição de dados geográficos para serem utilizados em Sistemas de. Acesso em 16 de 2 de 2013, disponível em www.geolab.faed.udesc.br: http://www.geolab.faed.udesc.br/sites_disciplinas/geoprocessamento_aplicado_ao_p lanejamento/docs/apostila_sig\%5B1\%5D.pdf

FONSECA, F. P. (2004). A inflexibilidade do espaço cartográfico, uma questão para a Geografia análise das discussões sobre o papel da cartografia. Tese de Doutorado. São Paulo: FFLCH-Universidade de São Paulo.

FOUCAULT, M. (2009). Microfísica do Poder. São Paulo: Graal.

GLEZER, R. (2007). Persistências do Antigo Regime na legislação sobre a propriedade territorial urbana no Brasil: o caso da cidade de São Paulo (1850-1916). Revista Complutense de Historia de América , 33, 197-215.

GOMES, M. d. (2004). Velhos Mapas, Novas Leituras: Revisitando a História da Cartografia. GEOUSP - Espaço e Tempo , 67-79.

GOUVÊA, J. P. (2010). Cidade do mapa. A produção do espaço de São Paulo através de suas representações cartográficas. Dissertação de Mestrado. São Paulo: FAU-Universidade de São Paulo.

GREGORY, I., \& ELL, P. (2007). Historical GIS: Technologies, Methodologies, and Scholarship. Cambridge: Cambridge University. Edição para Kindle.

GUEDES, M. J. (1968). Brasil-costa norte : cartografia portuguesa vetustissima; edicao comemorativo do amazonas. Rio de Janeiro: Serviço Doc Geral da Marinha.

HARLEY, B. (2005). La Nueva Naturaleza de los Mapas. Mexico: Fondo de Cultura Economica. 
HARLEY, B., \& WOODWARD, D. (1987). History of Cartography. Vol.1. Chicago: The University of Chicago Press.

HOLANDA, S. B. (2008). Caminhos e Fronteiras (3aㅡ edição ed.). São Paulo: Cia. das Letras.

HOLANDA, S. B. (1995). Raízes do Brasil (26ª edição ed.). São Paulo: Cia. das Letras.

IBGE. (1999). Manuais Técnicos em Geociências, número 8. Noções básicas de Cartografia. São Paulo: IBGE.

IDOETA, Irineu; IDOETA, Ivan V.; CINTRA, Jorge P. São Paulo vista do alto, 75 anos de aerofotogrametria. São Paulo: Érica, 2004.

JACOB, C. (1992). L'empire des cartes. Approche théorique de la cartographie à travers l'histoire. Paris: Albin Michel.

JOLY, F. (1990). A cartografia. Trad: Tânia Pellegrini. Campinas, SP: Papirus.

JORGE, J. (2003). Rios e Várzeas na Urbanização de São Paulo 1890-1940. Revista Histórica , 9-15.

KANTOR, I. (2009). Cartografia e diplomacia:usos geopolíticos da informação toponímica (1750-1850). Anais do Museu Paulista , 39-61.

KANTOR, I.(2007). Usos diplomáticos da ilha-Brasil polêmicas cartográficas e historiográficas. Varia hist. [online]. vol.23, n.37, pp. 70-80. http://www.scielo.br/scielo.php?script=sci_abstract\&pid=S0104-

$87752007000100005 \&$ Ing=en\&nrm=iso\&tlng=pt acesso em, 05/05/2010.

LACOSTE, Y. (1997). A Geografia - Isso serve, em primeiro lugar, para fazer a guerra (4 ed.). (M. C. França, Trad.) Campinas: Papirus.

LANGENBUCH, J. R. (1971). A Estruturação da Grande São Paulo: Estudo de Geografia Urbana. Rio de Janeiro: IBGE.

LEVY, J., \& LUSSAULT, M. (2003). Dictionnaire de la Géographie et de L'espace des Sociétés. Paris: Belin.

LIBAULT, A. (1975). Geocartografia. São Paulo: Ed. Nacional; Ed. da Universidade de São Paulo.

MARINS, P. C. (2004). "Tensões sociais na gestação da metrópole". In: C. M. Campos, L. H. Gama, \& V. Sacchetta, São Paulo, metrópole em trânsito: percursos urbanos e culturais. São Paulo: SENAC.

MARQUES, M. (1978). A Estruturação da Rede viária terrestre de São Paulo. Boletim Paulista de Geografia , 47-72. 
MARTINELLI, M. (2003). Mapas da Geografia e Cartografia Temática. São Paulo: Contexto.

MARTINELLI, M. (2003). Mapas da Geografia e Cartografia Temática. São Paulo: Contexto.

MARTINS, J.S. (2004). A Ferrovia e a modernidade em São Paulo: a gestação do ser dividido.Revista da Universidade de São Paulo.63. p.6-15.

MATOS, J. (2008). Fundamentos de Informação Geográfica. (5ª̣ed.). Lisboa-Porto: LIDEL.

MATOS, O. N. (1990). Café e ferrovias: a evolução ferróviária de São Paulo e o desenvolvimento da cultura cafeeira . Campinas: Pontes.

MEGALE, J. F. (1984). Geografia. In: M. Sorre. São Paulo: Ática.

MOINBEIG, P. (1954). Aspectos Geográficos do Crescimento da Cidade de São Paulo. Boletim Paulista de Geografia , N.16.

MONBEIG, P. (1957). Novos Estudos de Geografia Humana Brasileira. São Paulo: DIFEL.

MONBEIG, P. (1984). Pioneiros e Fazendeiros de São Paulo.Trad.França, A.e SILVA, R.A. São Paulo: HUCITEC, POLIS.

MORAES, A. C. (1991). Ideologias Geográficas. São Paulo: HUCITEC.

MORAES, A. C. (1994). Geografia Pequena História Crítica (13ª ed.). São Paulo: HUCITEC.

MORSE, R. M. (1970). Formação Histórica de São Paulo (De Comunidade à Metrópole). São Paulo: DIFEL.

MOTA, C. G. (2003). São Paulo:Exercício de Memória IN ESTUDOS AVANÇADOS $17(48)$.

PANOFSKY, E. (2009). Significado nas Artes Visuais. São Paulo: Perspectiva.

PASSOS, M. L. P. (2009). Desenhando São Paulo: Mapas e Literatura: 1877-1954. São Paulo Editora Senac São Paulo: Imprensa Oficial.

PÉREZ MACHADO, R. P. (2000). Um modelo geoespacial de uso do solo e demografia: o caso do município de São Paulo. Universidade de São Paulo:São Paulo: Tese de Doutoramento.

PÉREZ MACHADO, R. P. (2010). Sobreposição da cartografia digital vetorial às cartas e mapas históricos da Cidade. $3^{\circ}$ Simpósio Iberoamericano de História da Cartografia. São Paulo. 
PORTA, Paula(2004). História da Cidade de São Paulo: a cidade colonial 15541822. São Paulo: Paz e terra.

PRADO JUNIOR, C.(1998). A cidade de São Paulo. (2ª Ed.). São Paulo: Brasiliense.

REIS, N. G. (2004). São Paulo: Vila, Cidade, Metrópole. São Paulo.

REPARTIÇÃO DE ESTATístICA E DO ARCHIVO DE SÃO PAULO . (1907). Anuário Estatístico de São Paulo de 1905. São Paulo: SEADE.

ROBINSON, A. H.(1967) The Thematic Maps of Charles Joseph Minard IN Imago mundi: Vol. 21, pp. 95-108.

ROLNIK, R. (2007). A cidade e a lei: legislação, política urbana e territórios na cidade de São Paulo. São Paulo: FAPESP Studio Nobel.

RUMSEY, D. (2002). Past Time, Past Place: Gis for History. Redlands, California: ESRI.

SABER, Aziz Ab'. O sítio embrionário de São Paulo. In: São Paulo, metrópole em trânsito : percursos urbanos e culturais / organizadores Cândido Malta Campos, Lúcia Helena Gama, Vladimir Sacchetta -- São Paulo : SENAC São Paulo, 2004.

SAES, F. A. (1981). As Ferrovias de São Paulo, 1870-1940:expansão e declínio do transporte ferroviário em São Paulo. São Paulo: HUCITEC.

SAID, E. W. (1978) The Problem of Textuality: Two Exemplary Positions. Critical Inquiry, Vol. 4, №. 4, pp. 673-714. www.jstor.org/stable/1342951 acesso em 12/11/2010.

SAINT- HILAIRE, A. (1976). Viagem à província de São Paulo. São paulo: EDUSP.

SALGADO, I. (Outubro de 2009). Carl Friederich Joseph Rath: o ‘higienismo' na formação do corpus disciplinar do urbanismo na cidade de São Paulo Arquitextos. Acesso em 24 de Outubro de 2010, disponível em Vitruvius:

http://www.vitruvius.com.br/revistas/read/arquitextos/10.113/18

SALICHTCHEV, K.A. (1988) "Algumas Reflexões Sobre o Objeto e Método da Cartografia Depois da Sexta Conferência Cartográfica Internacional" IN Cartografia Temática, Seleção de Textos, AGB, São Paulo: 17-22.

SANTOS, M.D. (2007). Técnicas e Elementos da Cartografia da América Portuguesa e do Brasil Império in COSTA, Gilberto (org.). Roteiro Prático de cartografia da América portuguesa ao Brasil Império. Editora UFMG: Belo Horizonte..

SANTOS, M. (2009). Metrópole Corporativa Fragmentada. São Paulo: EDUSP.

SANTOS, M(1997a). Espaço \& Método. 4ª ed. São Paulo: NOBEL. 
SANTOS, M(1997b). A Natureza do Espaço: Técnica e Tempo, Razão e Emoção. (2 ${ }^{\mathrm{a}}$ Ed). São Paulo: HUCITEC,

SANTOS, M.(1996). Metamorfoses do Espaço Habitado: Fundamentos Teóricos e Metodológicos da Geografia. $4^{a}$ ed. São Paulo: HUCITEC.

SANTOS, M. (1994) Técnica Espaço Tempo: Globalização e meio técnico-científico informacional. São Paulo: HUCITEC.

SANTOS, M.; SILVEIRA, M. L.(2004) O Brasil: Território e Sociedade no Início do Século XXI. $6^{\mathrm{a}}$ ed. Rio de Janeiro: Record.

SCARLATO, F. C. (1998). O rEal e o Imaginário no Bexiga: Autofagia e Renovação Urbana no Bairro. Tese de Doutorado São Paulo: FFLCH-Universidade de São Paulo.

SÃO PAULO (SP). Comissão do IV Centenário da Cidade. (1954). São Paulo antigo plantas da cidade. São Paulo .

SÃO PAULO, metrópole em trânsito: percursos urbanos e culturais (2004) / organizadores Cândido Malta Campos, Lúcia Helena Gama, Vladimir Sacchetta -São Paulo : SENAC São Paulo.

SILVA, E. M. (2012). Práticas de Apropriação e Produção do Espaço em São Paulo: A Concessão de Terras Municipais Através das Cartas de Datas (1850-1890). São Paulo: Dissertação de Mestrado FAU USP.

SILVA, J. . (1984). São Paulo, 1554-1880 : discurso ideológico e organização espacial. São Paulo: Editora Moderna.

SIMONI, N. L. (2009). A Planta da cidade de São Paulo de 1897:uma cartografia da cidade existente ou da cidade futura? III Simpósio Luso-Brasileiro de Cartografia Histórica .

SINGER, P. I. (1977). Desenvolvimento econômico e evolução urbana : análise da evolução econômica de São Paulo, Blumenau, Porto Alegre, Belo Horizonte e Recife. São Paulo : Nacional

SKINNER, Q. (1985). The Return of Grand Theory in the Human Sciences. UK:Cambridge University Press.. 215p.

SOUZA, M. A. (1994). A Identidade da Metrópole: verticalização em São Paulo. São Paulo: HUCITEC.

STIEL, W. C. (1978). História dos Transportes Coletivos em São Paulo. São Paulo: Mc-Graw-Hill do Brasil Ldta.

SZMRECSÁNY, T. (1986). Apontamentos para uma história financeira do grupo Light no Brasil, 1899/1939. Revista de Economia política , 6, 132-135. 
TOLEDO, B.L. (1980). São Paulo três cidades em um século.São Paulo. (4⿳亠丷厂 Ed.) Cosacnaify, Livraria Duas Cidades, Prefeirura Municipal da Cidade de São Paulo. UNZELTE, C. (2003). A Família Bresser na História de São Paulo. Acesso em 28 de 02 de 2013, disponível em Bresser-Pereira Website: http://www.bresserpereira.org.br/index.asp

VILLAÇA, F. (2001). Espaço intra-urbano no Brasil. São Paulo: Studio Nobel.

VOLPATO, G.L. (2010). Método Lógico para Redação Científica.Botucatu: Best Writing.

DOCUMENTOS CARTOGRÁFICOS

ACERVO FUNDAÇÃO ENERGIA E SANEAMENTO. Planta Geral da Cidade de São Paulo, São Paulo, 1905, 1:6:500.

BOYER, Henry. Planta da Cidade de São Paulo levantada pela Companhia Cantareira e Esgotos 1881.(cópia de Domingues dos Santos), São Paulo, 1954, $1: 5.000$.

BRAZILIAN TRACTION LIGHT \& POWER COMPANY LTD. Map of the City of São Paulo: showing ublic utilities operated by subsidiary companies. São Paulo, 1924, escala gráfica em milhas.

BRAZILIAN TRACTION LIGHT \& POWER COMPANY LTD. Plan of the City of São Paulo and Environs. São Paulo, 1927, 1:40.000.

BRESSER, C.A. Mappa da Cidade de São Paulo e seus Subúrbios 1847. São Paulo: $1954,1: 5.800$

CARDIM, G. Planta Geral da Capital de São Paulo 1897. São Paulo, 1954, $1: 20.000$. 
CARDOSO, J.P. - COMISSÃO GEOGRAPHICA E GEOLOGICA. Planta Geral da Cidade de São Paulo com indicações diversas. São Paulo, 1914, 1:20.000.

COCOCl, A.M. e COSTA, L. F. Planta Geral da Cidade de São Paulo. São Paulo: Adotada pela Prefeitura Municipal para uso de suas repartições, 1905, 1:20.000.

LIMA, G.C.B.(org.) . Planta da Cidade de São Paulo em 1850. São Paulo, s/data, s/escala.

MARTIN, J e ABULQUERQUE, F. Mappa da Capital da Província de S.Paulo 1877. São Paulo, 1877, 1:3.500.

MARTIN, J. Planta da Capital do Estado de S. Paulo e seus arrabaldes 1890. São Paulo, 1954, 1:6.000.

PREFEIRURA DO MUNICìIO DE SÃO PAULO. Planta da cidade de S. Paulo: mostrando todos os arrabaldes e terrenos arruados. Rio de Janeiro, 1924, 1:30.000. Disponível em <: http://smdu.prefeitura.sp.gov.br/historico demografico/img/mapas/1924.jpg> Acesso em 10/out/2011.

RATH, C. F. (atribuída). Planta da Cidade de São Paulo 1868. São Paulo, 1954, escala aprox.1:10.000. 


\section{ANEXO 1 - Delimitação do centro expandido da cidade de São Paulo conforme a COMPANHIA DE ENGENHARIA DE TRÁFEGO - CET.}

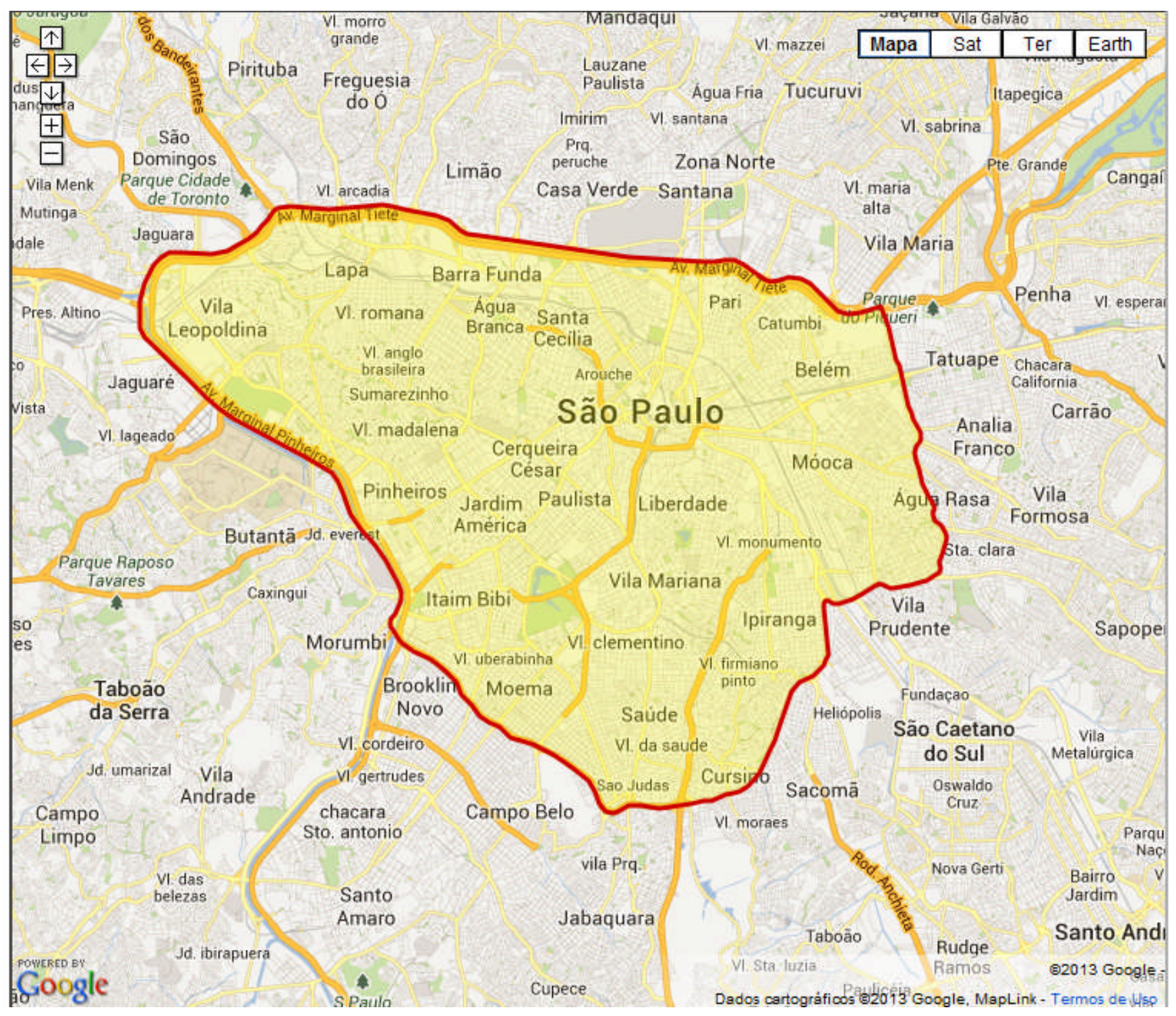

Fonte: http://www.cetsp.com.br acesso em 01/08/2013 